Portland State University

PDXScholar

5-8-1975

\title{
The Effect of Human Activity on the Middle Course of the Tualatin River, Oregon
}

Lolita M. Carter

Portland State University

Follow this and additional works at: https://pdxscholar.library.pdx.edu/open_access_etds

Part of the Water Resource Management Commons

Let us know how access to this document benefits you.

\section{Recommended Citation}

Carter, Lolita M., "The Effect of Human Activity on the Middle Course of the Tualatin River, Oregon" (1975). Dissertations and Theses. Paper 227.

https://doi.org/10.15760/etd.227

This Dissertation is brought to you for free and open access. It has been accepted for inclusion in Dissertations and Theses by an authorized administrator of PDXScholar. Please contact us if we can make this document more accessible: pdxscholar@pdx.edu. 
THE EFFECT OF HUMAN ACTIVITY ON THE

MIDDLE COURSE OF TEE TUA'ATIN RIVER, OREGON

by

LOLITA M. CARTER

A thesis submitted in Fartial fulfiliment of the requirements for the degree of

DOCTOR OF PHILOSOPHY

in

ENVIRONMENTAL SCIENCE-BIOLOGY

Portland State University 1975

Copyright (O) Lolita M, Cartsr, 1975 
TO THE OFEICE OF GRADUATE STUDIES AND RESEARCH:

The members of the Committee apfrove the tinesis of Lolita M. Carter presented May 8, 2975.
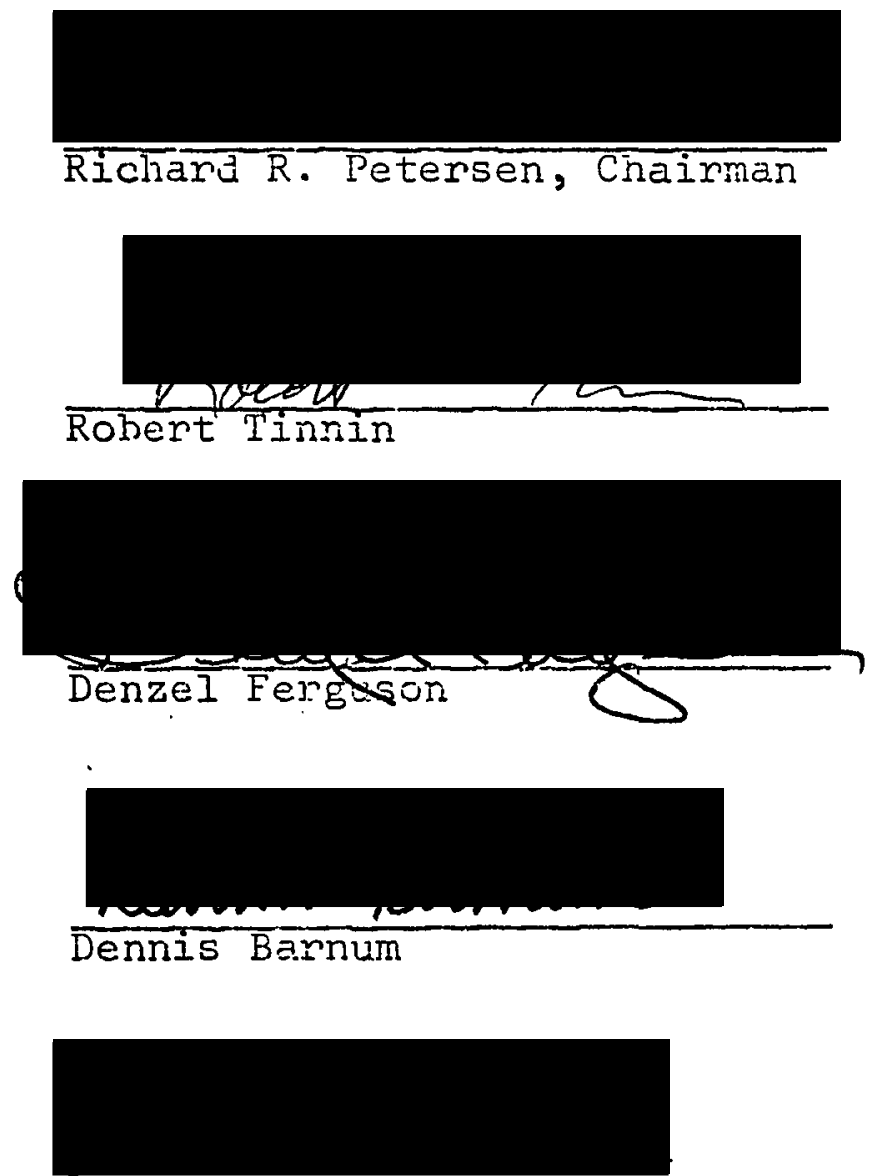

Carl Bachhuber

APPROVED:

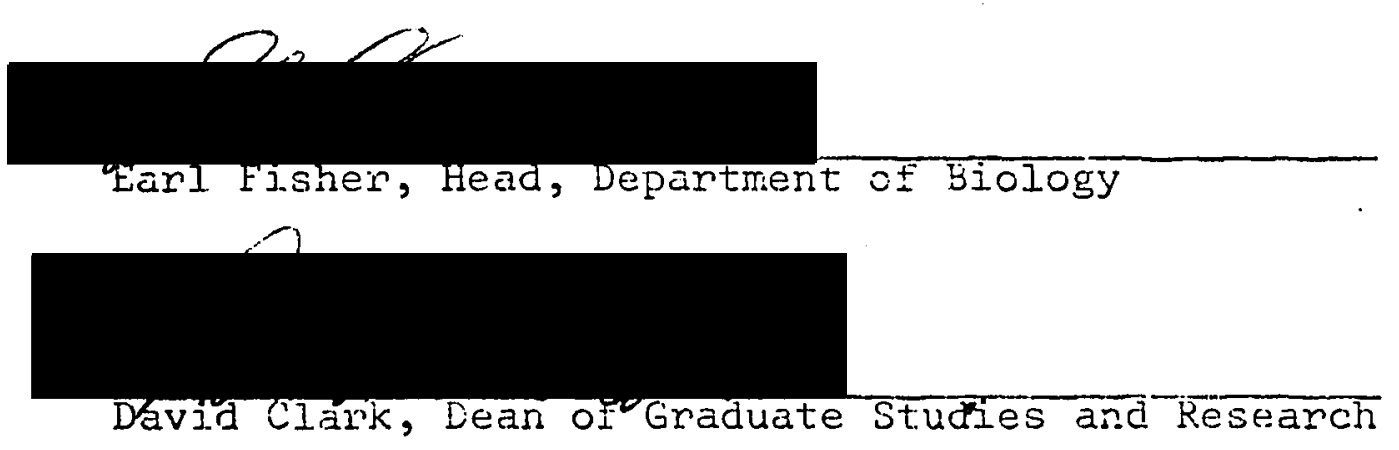


AN ABSTRACT OF TYE THESIS OF LOlita M. Carter for the Doctor of Philosophy in Ënvironmental Science-Biology presented 8 May 1975.

Title: The Effect of Human Activity on the Middle Course of the Tualatin River, Oregon

APPROVED BY MEMBERS OF THE THESIS COMMITTEE:
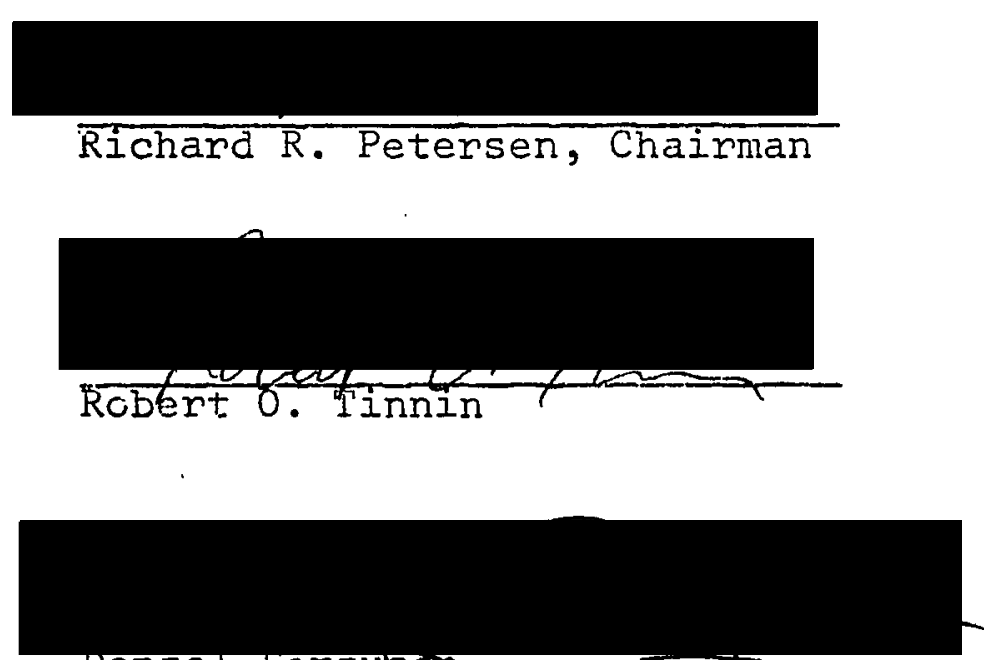

Denze1 Ferguson
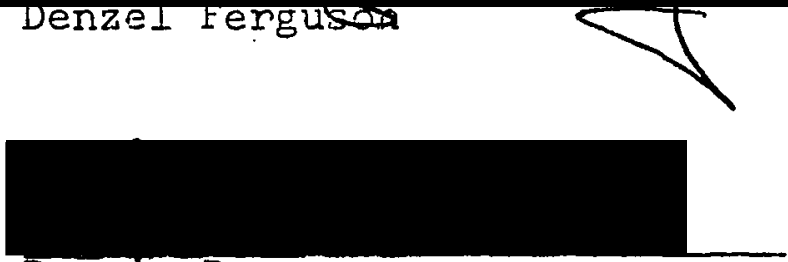

Dennis Barnum

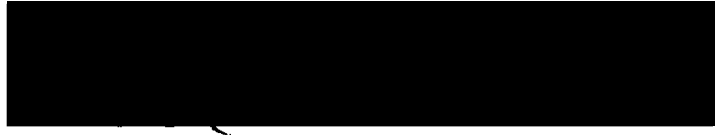

Carl Bachhuber 


\section{ABSTRACT}

A diurnal study of biological, chemical, and physical parameters was made on the middle course of the Tualatin River, which drains a $1840 \mathrm{~km}^{2}\left(711 \mathrm{mi}^{2}\right.$ ) basin adjacent to metropolitan Pontland, Oregon. This portion of the river lies along land in transition of use from rural agriculture to hignily urbanized development.

There is no nutrient loading of the river from farming practices because there was no return of water from summer, sprinkler irrigation of commercial crops. However, irrigation significantly reduces the volume of water in the river in the summers.

Effluents from sewage treatment plants flowing into the tributaries that drain the highly urbanized eastern areas of the river basin are the main cause of degraded water quality and algal biomass in the lower reaches of the river. The Tualatin River above the mouth of Rock Creek is relatively unpolluted, but downstream from Rock Creek the river is highly eutrophic and during the periods of low flow in the summer serves as a sewage oxidation channel. In this sane portion of the river there is also evidence that nitrification occurs.

Winter floods leach nitrate-nitrogen from the basin, but in the summer the possibility exists that nitrate-nitrogen may be a limiting nutrient for algal productivity in the river above Hillsboro. 
The principal source of poly-phosphates is from sewage treatment plant effluents, but concentrations of poly-phosphates in the middle reaches of the river indicate that there is a natural source of poly-and/or ortho-phosphates in the watershed. Removal of phosphorous compounds from the effluents probably would not affect the large algal blooms occurring in the river below Hillsboro.

Trace metal analyses indicated that iron, potassium, nickel, zinc, lead, copper, cobalt, and chromium concentrations were higher during flooding. Turbidity readings suggest that these trace elements are deposited on the floodplain.

Melted snow water, which caused one of the winter floods, contained concentrations of zinc, copper, and lead greater than those found in the river during the flood.

Greater concentrations of arsenic and zinc came from farmland than from urban areas.

Diversities of the net plankton as measured by the Shannon-Weaver Index did not change from season to season, nor with downstream flow. Species in the net plankton were benthic forms at the upper stations and planktonic forms downstream from Hillsboro, especially in the summer when the reduced flow caused the river to pond. The enriched effluents from Rock Creek did not affect the diversity of the organisms downstream, but supported a larger biomass. By rating the diversities with other studies it was found that 
the middle course of the Tualatin River is eutrophic but not heavily polluted.

A diurnal study was especially valuable from April to September, inclusive, when insolation and temperatures favored biological activities such as photosynthesis and decomposition. From November to January little diurnal change in the water quality was found.

Farming had its greatest impact in the quantity of water and municipalities had a more serious impact on the water quality in the middle course of the Tualatin River. Even with the reduced flow from agricultural irrigation, the river can maintain relatively good water quality, except when effluents from sewage plants caused highly eutrophic conditions. 


\section{ACKNOWLEDGMENTS}

For their support and help, with great appreciation, I acknowledge and thank:

Dr. Richard R. Petersen, my major professor, and the members of my thesis committee: Dr. Robert Tinnin and Dr. Denzel Ferguson of the Biology Department, Dr.. Dennis Barnum of the Chemistry Department and Dr. Carl Bachhuber of the Physics Department. Dr. Marvin Beeson of the Earth Sciences Department made valuable comments concerning geochemistry.

Dean Karl Dittmer, Dr. Earl Fisher, and Dr. Richard Forbes for their administrative support.

Mr. Edison L. Quan, Dr. Douglas Larson, Dr. Warren Westgarth, Mr. Glen Carter, and Mr. Robert McHugh of the Oregon State Department of Environmental Quality, who loaned me laboratory space and equipment, and pointed out pitfalls while giving practical advice and encouragement.

Dr. Daniel Krawscysk and Mr. Earl Kari of the Pacific Northwest Environmental Research Laboratory of the US Ervironmental Protection Agency, who implemented some of the analytical work on trace elements.

And Amanda, Lona, Ian, Galen, and Glen, who learned that the old wives' tale---if you educate a woman, you educate a family---was indeed true. 
TABLE OF COITENTS

PAGE

ACKNOWLEDGEMENTS . . . . . . . . . . . . . . iii LIST OF TABLES . . . . . . . . . . . . . . . . vi vi LIST OF FIGURES. . . . . . . . . . . . . . . . vii

CHAPTER

I INTRODUCTION . . . . . . . . . . . . 1

II PHYSICAL DESCRIPTIONS. . . . . . . . . . 3

Geographical and Hydrological Description of the Tualatin River Basin . . . . 3

Sampling Stations and Tributaries ... . 10

Geological Description. . . . . . 18

III HISTORICAL BACKGROUND. . . . . . . . . 26

IV METHODS AND MATERIALS. . . . . . . . 33

V OBSERVATIONS AND RESULTS . . . . . . . 4 42

Physical parameters......... . 42

Chemical parameters . . . . . . 56

- Biological parameters .. . . . . . 102

Non-point nutrient sources. . . . . . 108

VI CONCLUSIONS. . . . . . . . . . . . 118

Discussion relating to the development of the management of water in the Tualatin Basin......... 118

Summaries . . . . . . . . . . 132

Conclusions ........... 136 
A Statistical Data for Diversity Study . . . . . 150

B Check Iist of the Net Plankton . . . . . . . 152

C Taxonomic References . . . . . . . . . . 160

D Listing of the raw data. . . . . . . . . . . 161 


\section{IIST . OF TABLES}

TABLE

PAGE

I Flow and Discharge Values among the 8 Major

Subbasins of the Tualatin River . . . . . .

II Location of Sampling Stations, Tributaries, and

Out-falls along the Middle Course of the

Tualatin River . . . . . . . . . 11

III Flow of the Tualatin River and its Tributaries . . 43

IV Velocity of the Water at Farmington Bridge, July

1972 to September 1973 . . . . . . . 48

V Trace Element Concentrations in Selected Water

Samples from the Tualatin River . . . . . 70

VI Shannon-Weaver Diversity Index, Tualatin River

Sampling Stations, August 1972 to August 1973 . 104

VII Estimates of the Population of the Net Plankton in

the Tualatin River . . . . . . . . 105

VIII Net Plankton Dominants at Selected Stations in the Tualatin River ............. 107

IX Nutrient Contributions in Street Drainage Ditches . 110

X Nutrient Contributions in Precipitation . . . . . 112

XI Concentrations of Nutrients in Selected Farm

Drainage Ditches, Tualatin River Basin . . . II3

XII Location of Non-point Source Sampling Sites . . . 114 


\section{LIST OF FIGURES}

FIGURE

PAGE

1 The Tualatin River basin (modified from Swift 1971). 4

2 Slope of the Tualatin River: RM 30 to its origin . . 5

3 Monthly mean streamflow discharged from the Tualatin River Basin, 1929-1947 .......... 7

4 Major subbasins of the Tualatin River basin . . . . 8

5 Gaston, the upstream sampling station, summer 1973 . 19

6 . Farmington, the last sampling station downstream, summer 1973 . . . . . . . . . . 19

7 Hillsboro sampling station: Oregon Highway 219 bridge during the flood of 1972 ..... . 20

8 Hillsboro sampling station: Oregon Highway 219 bridge summer 1973 at zero flow..... . 20

9 The Industrial Sewer Farm for the Hillsboro-Westside sewage treatment plant at floodstage, 1972 . • 21

10 The Industrial Sewer Farm for the Hillsboro-Westside sewage treatment plant, summer 1973 . . . . . 21

11 Rood Road Station: looking downstream at zero flow, summer 1973 . . . . . . . . . . . . . .

12 Rood Road Station: looking downstream at flood time, 1972 . . . . . . . . . . . . . .

13 Rood Road Station: an overhead view of the clay dike across the channel, summer 1973 . . . . .

14 Diversified agriculture on the floodplain at Cornelius.23 
viii

FIGURE

PAGE

15 Average annual flow, Tualatin Fiver and selected tributaries in approximate volume relationship of each (STR 1969). . . . . . . ... . 46

16 The rate of flow in $\mathrm{m} / \mathrm{s}$ or fps at Farmington Bridge, 1972-1973............ 49

17 Tempenature of the water in degrees Celsius in the Tualatin River, 1972-1973. . . . . . . .

I8 Chemical parameters in Rock Creek, a tributary of the Tualatin River between Rood Road and Farmington Stations 1973 . . . . . . . . .

19 Turbidity in Jackson Turbidity Unito (formazine standard) in the Tualatin River, 1973. . . .

20 Dissolved oxygen in $\mathrm{mg} / \mathrm{I}$ in the Tualatin River, 19721973.................

21 Biochemical oxygen demand in $\mathrm{mg} / \mathrm{I}$ in the Tualatin River, 1972-1973 . . . . . . . . .

22 Total alkalinity in $\mathrm{mg} / \mathrm{l}$ as $\mathrm{CaCO}_{3}$ in the Tualatin

River, 1972-1973 and bicarbonate alkalinity in

$\mathrm{mg} / \mathrm{I}$ as $\mathrm{CaCO}_{3}$ at Farmington Station 1973. • •

$23 \mathrm{pH}$ in standard units in the Tualatin River, 1972-1973. 67

24 Concentration of nitrate-nitrogen in $\mathrm{mg} / \mathrm{l}$ in the

Tualatin River, 1972-1973. . . . . . . .

25 Concentration of ammonium-nitrogen in $\mathrm{mg} / \mathrm{l}$ in the Tualatin River, 1972-1973.........

26 Concentration of acid hycrolyzable phosphates in 
FIGURE

PAGE

mg/I from unfiltered water samples in the Tualatin River 1972-1973... . . . . . .

27 Corcentrations of inorganic carbon in $\mathrm{mg} / \mathrm{I}$ in the Tualatin River, 1972-1973... . . . . . .

28. Atomic ratio of $N: P$ in the Tualatin River, 19721973... . . . . . . . . . . . .

29 Atomic ratios of $\mathrm{C}: \mathrm{N}$ in the Tualatin River, 1972-

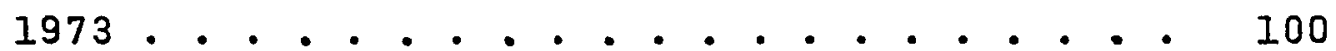

30 Sampling stations, sewage treatment plants, and tributaries along the middle course of the Tualatin River. . . . . . . . . . . . 117 


\section{CHAPTER I}

\section{INTRODUCTION}

The environmental impact of a rapidly increasing human population has become critical to the wise use of land and water in the Tualatin River drainage basin. The middle course (Gaston to Farmington) of the Tualatin River was studied to determine the effects which various rural and municipal uses have on its water quality. While there is ample winter rainfall to support agriculture and human populations, the lorg, dry summers bring scant precipitation and critical shortages of water when it is needed most. The quality and quantity of water in the Tualatin River reflect this summer burden.

Several studies have been made on the Tualatin River and its drainage basin by various governmental agencies for their specific purposes (Hart and Newcomb 1965; OSSA 1965, 1966, 1967; STR 1956, 1969; Swift 1971; Thompson et al. 1966; USACE 1953, 1969; USBR 1956, 1963; USGS 1956; USHEW 1962; Watson et al. 1923). My study, however, is the first composite study using chemical, physical, and biological parameters to determine the water quality and to relate all available information to man's use of the river water.

Analyses of chemical, physical, and biological parameters can assign changes in the river to natural or human 
causes, and if human to the role of specific human activities, such as farming and urban development, in altering the quantity or quality of water in the studied portion of the Tualatin River.

The projected value of this study is that it provides a baseline for future management of the water supply, use, and quality within the Tualatin River drainage basin. 
CHAPTER II

PHYSICAL DESCRIPTIONS

I GEOGRAPHIC AND HYDROLOGICAL DESCRIPTION OF THE TUALATIN BASIN

The Tualatin River begins in the Coast Range Mountains of northwestern Oregon, and meanders through an oval drainage basin, $65 \mathrm{~km}(40 \mathrm{mi})$ long and $40 \mathrm{~km}(25 \mathrm{mi})$ wide, on its $138 \mathrm{~km}$ (86 $\mathrm{mi}$ ) pathway to the Willamette River near West Linn (Figure 1). An area of $1841 \mathrm{~km}^{2}\left(711 \mathrm{mi}^{2}\right)$ 1ies within the drainage basin, almost equally divided between the upper hill country and a flat valley floor. Elevations in the upper basin approach $1040 \mathrm{~km}$ (3400 ft); most of the lower valley regions range between 30 and $60 \mathrm{~m}$ (100 to $200 \mathrm{ft}$ ).

At higher elevations the streambed has a gradient of about $2.3 \mathrm{~m} / \mathrm{km}$ (12 ft/mi)(Figure 2). Near Gaston, River Mile (RM) 62.3, the gradient is reduced to slightly over $0.6 \mathrm{~m} / \mathrm{km}$ ( $3 \mathrm{ft} / \mathrm{mi}$ ) and broad flood plains appear and persist in varying wiaths to near RM 7. Below Gaston the river gradient is but $0.2 \mathrm{~m} / \mathrm{km}$ ( $1 \mathrm{ft} / \mathrm{mi}$ ). From Hillsboro, RM 44.4, to Tualatin, RM 7, the gradient is only $0.04 \mathrm{~m} / \mathrm{km}$ $(0.2 \mathrm{ft} / \mathrm{mi})$ and certain lowlands along the way are often flooded during winter freshets. Flooding may last up to 6 weeks with little noticeable fluctuation.

The average annual discharge of the Tualatin River Basin is approximately $1.33 \times 10^{9} \mathrm{~m}^{3}\left(1.077 \times 10^{6} \mathrm{ac}-\mathrm{ft}\right)$. 


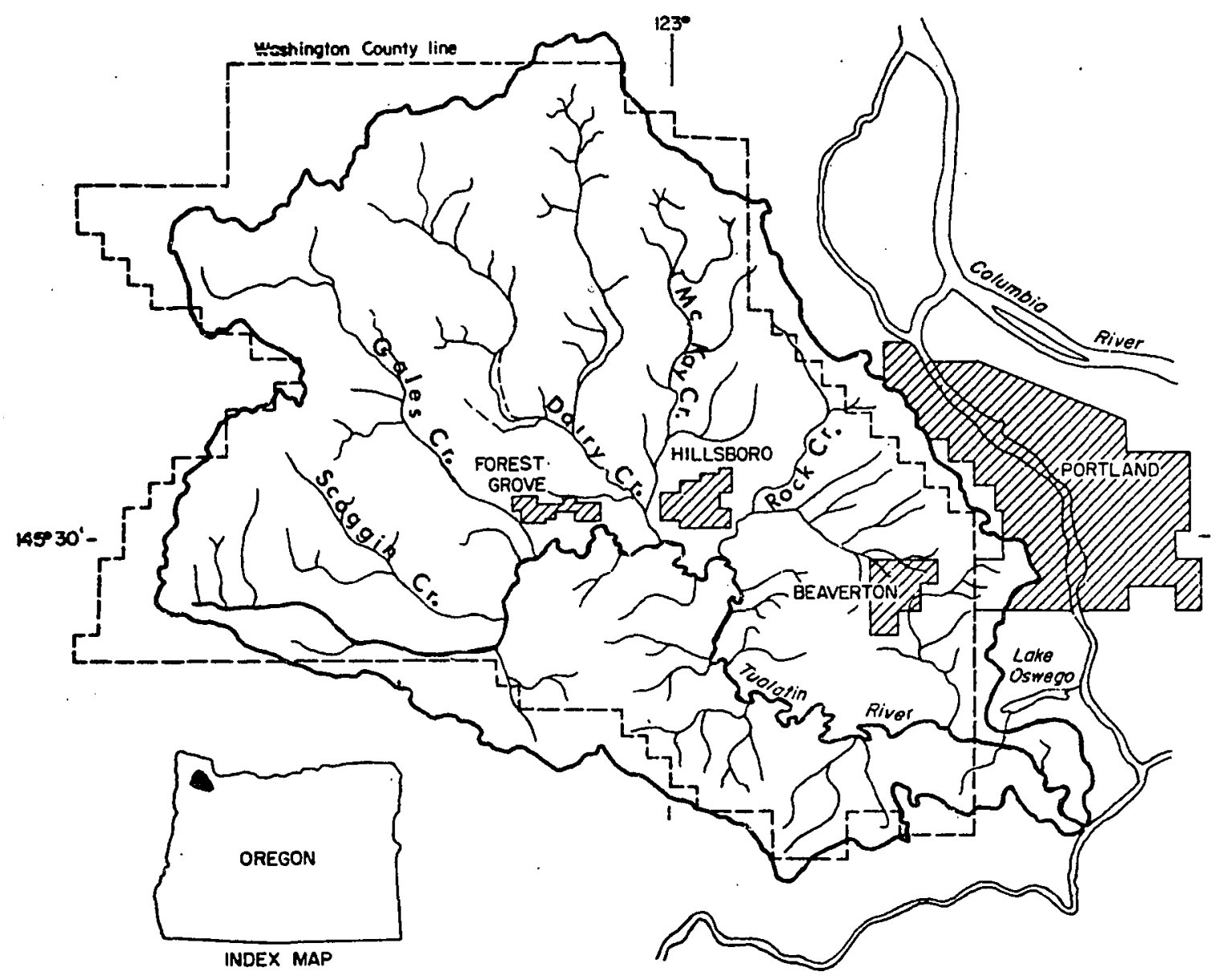

Figure 1. The Tualatin River Basin (modified from Swift 1971). 


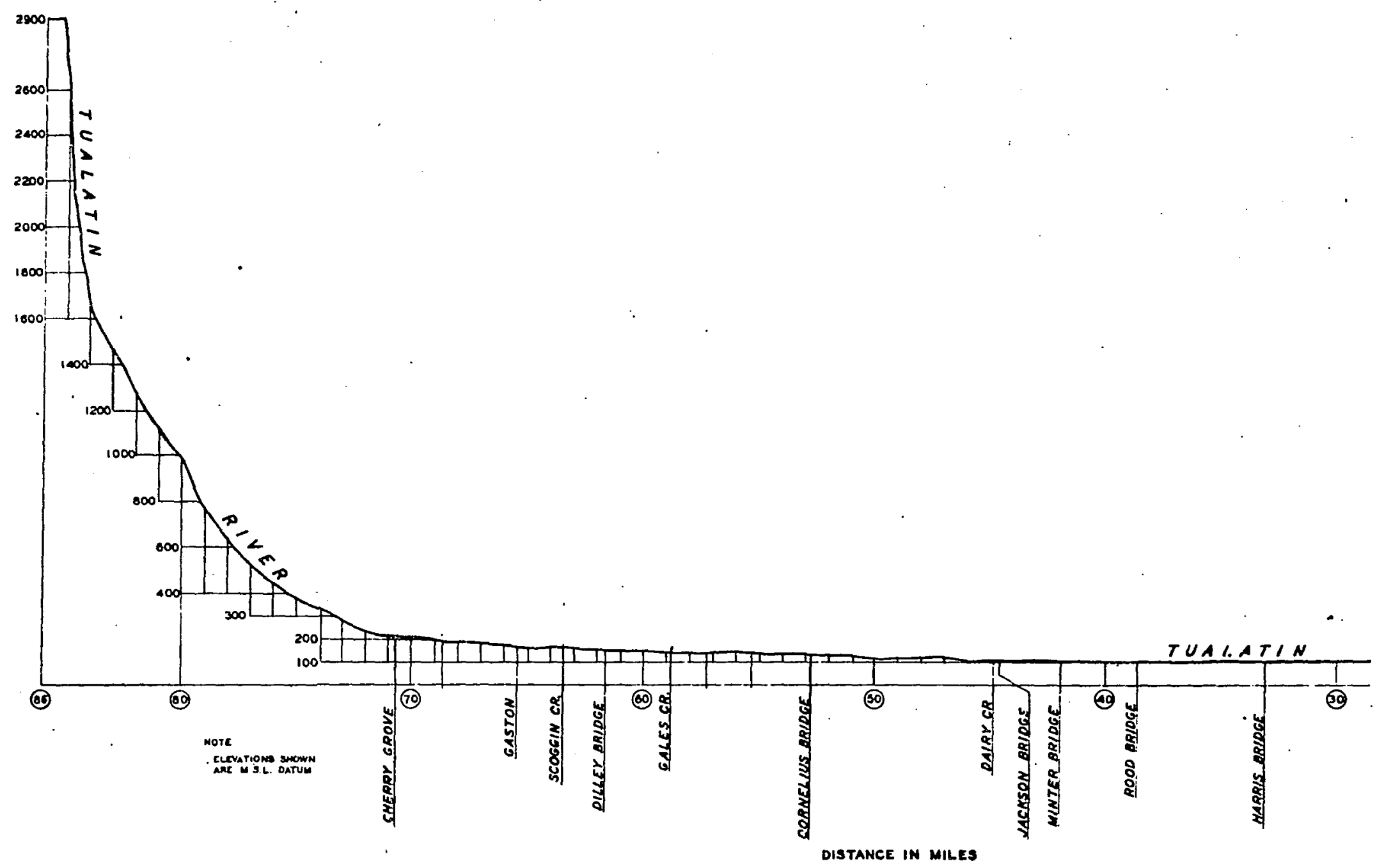

Figure 2. Slope of the Tualatin River: RM 30 to its origin. The middlecourse gradually slopes from Gaston to Farmington. 
The annual range is from $49 \%$ to $178 \%$ of the average annual discharge (Swift 1971). Of the average annual discharge volume, $10 \%$ occurs from May to October, $4 \%$ from June to September, $40 \%$ in January ind February, and $70 \%$ from December to March (Figure 3 ). This is a product of the Pacific Northwest Marine climate of mild, wet winters and dry, warm summers.

Of the 8 major subbasins of the Tualatin River drainage area only Fanno Creek does not discharge into the river's middle course (Figure 4). Gales Creek contributes the largest single flow to the main river, with the Upper Tualatin above Gaston being the second (Table 1). About 91\% of the annual flow of the Tualatin River Basin enters the river above $\mathrm{RM} 44$, just below the mouth of Dairy Creek (OSSA 1967). Table 1 shows the division of the average annual flow, the drainage area, and the discharge volume of each of the 8 major subbasins of the Tualatin River.

In August the average flow taken over a period of 33 years at the US Geological Survey Dilley gauge has been $0.5 \mathrm{~m}^{3} / \mathrm{s}(17 \mathrm{cfs})$. The average $(26 \mathrm{yr}$.$) flow from August$ below all the major tributaries is $0.3 \mathrm{~m}^{3} / \mathrm{s}$ ( 11 cfs). The decrease in flow was due to irrigation. It is common to have essentially zero flow in some portions of the nainstem river because all the water has been legally withdrawn (OSSA 1967). 


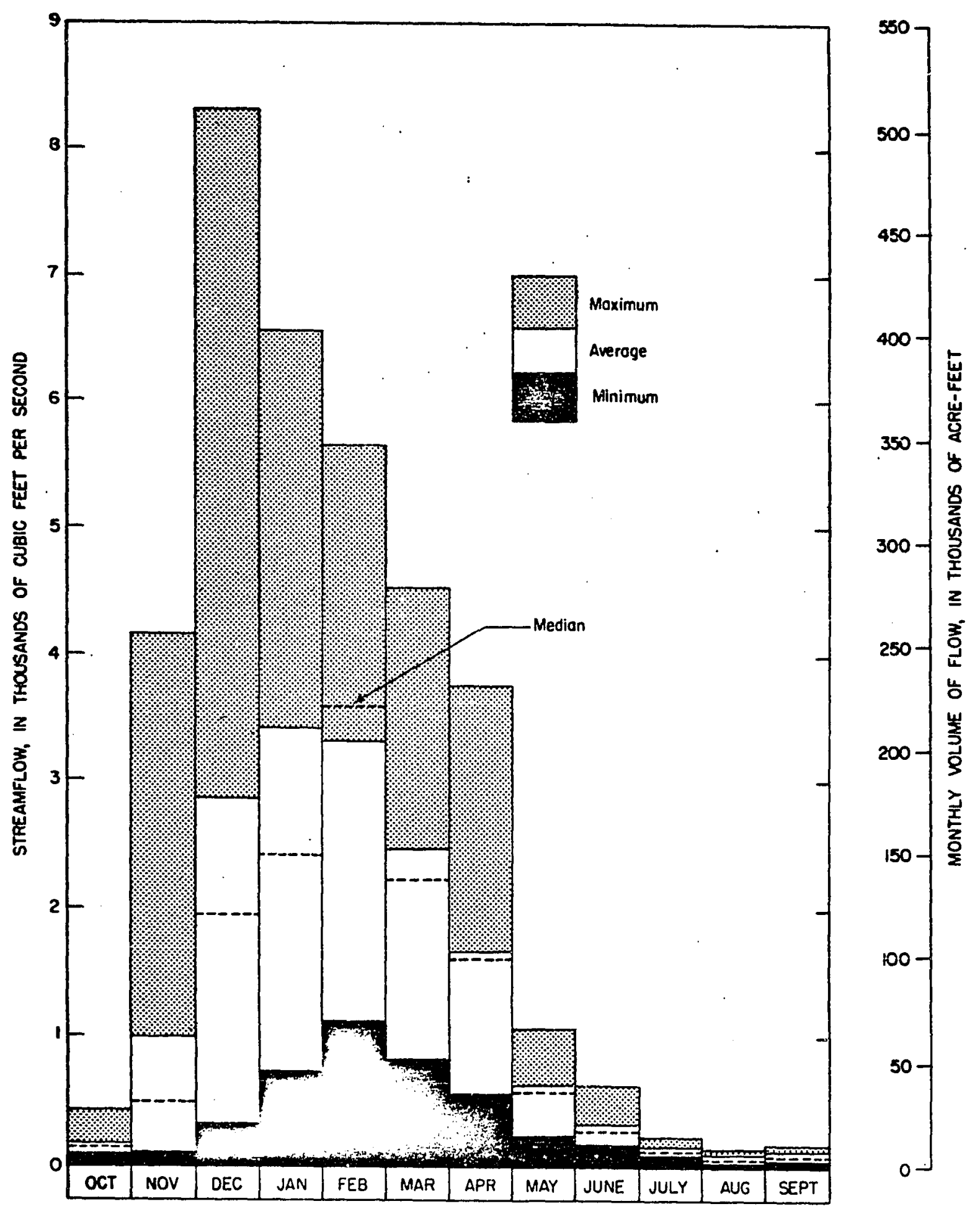

Figure 3. Monthly mean streamflow discharged from the Tualatin River Basin, 1929-1947 (Swift 1971). 


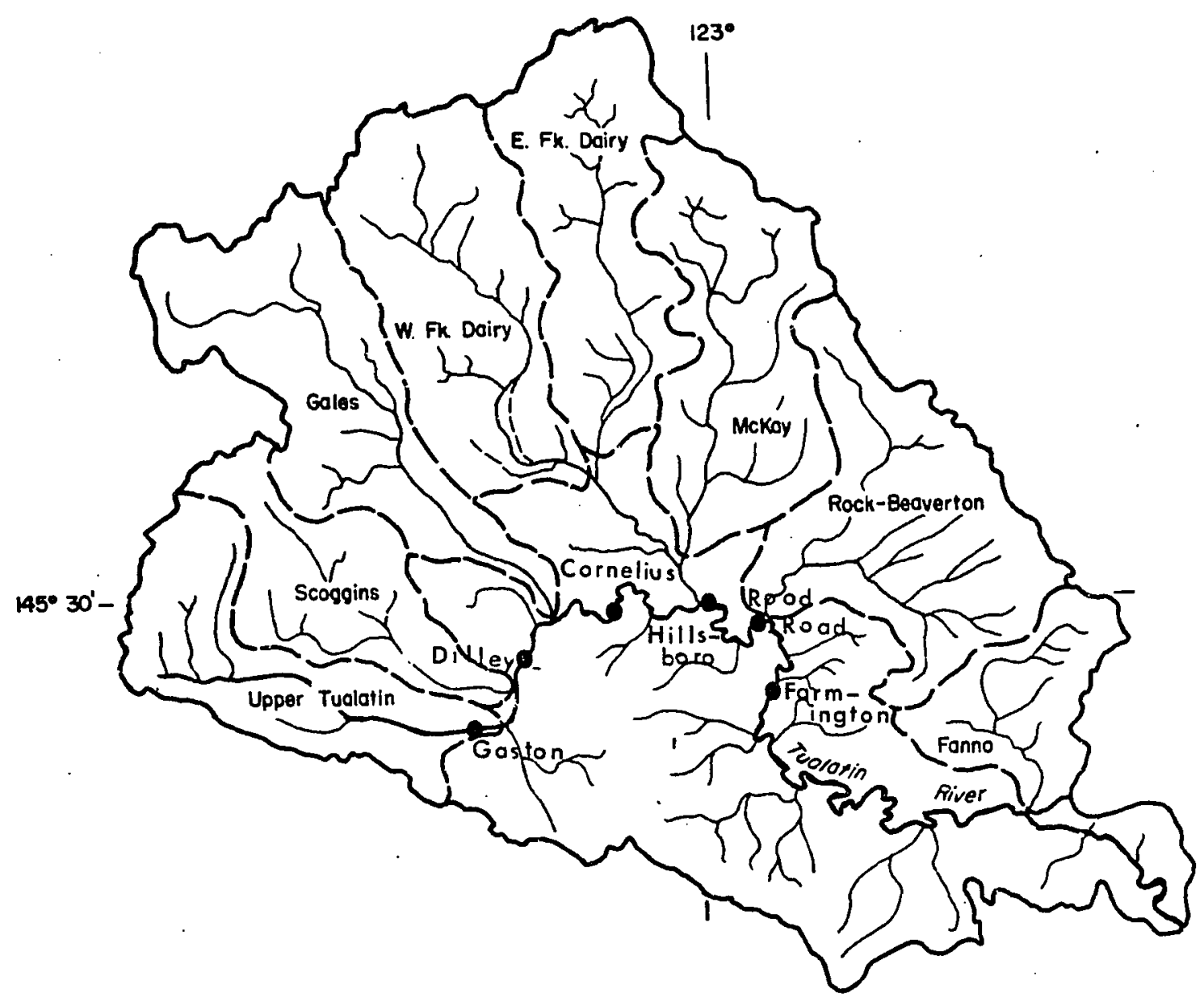

Figure 4. Major subbasins of the Tualatin Riven Basin and the sampling stations. 
TABLE I

FLOW AND DISCHARGE VALUES AMONG

THE 8 MAJOR SUBBASINS OF

THE TUALATIN RIVER

SUBDIVISION

Upper Tualatin

Scoggin Creek

Gales Creek

West Fork Dairy Creek

Last Fork Dairy Creek

McKay Creek

Rock-Beaverton Creeks

Fanno Creek
AVE. ANNUAL

FLOW

$\mathrm{m}^{3} / \mathrm{s}$

5.3

3.9

6.4

3.6

3.6

2.8

$2 \cdot 2$

1.1
DRAINAGE AREA

$\mathrm{km}^{2}$

132

112

191

200

170

171

192

82
AVERAGE

VOLUME

$\mathrm{m}^{3} / \mathrm{yr}$

$1.8 \times 10^{8}$

$1.3 \times 10^{8}$

$2.1 \times 10^{8}$

$1.5 \times 10^{8}$

$1.4 \times 10^{8}$

$1.4 \times 10^{8}$

$1.2 \times 10^{8}$

$0.5 \times 10^{8}$ 
Table II shows the specific locations of some of the major river features in the studied area.

A map of the middle course of the Tualatin River Basin showing the locations of the sampling stations for this study is given in Figure 4.

II GEOGRAPHIC DESCRIPTION OF THE SAMPLING STATIONS AND TRIBUTARIES

\section{Gaston}

The first sampling station is on the south side of the river in the town of Gaston, $60 \mathrm{~m}(200 \mathrm{ft})$ upstream from the old Highway 47 bridge at RM 62.3 (Figure 4). This station is at the downstream end of Patton Valley, a small flood plain of the upper Tualatin River.

Here the river bed is the coarse sands and silts. Winter scouring prevents the growth of any higher plants in the streambed, but the upper and middle courses of the Tualatin do have scattered, half-submerged logs and other forest debris in the water. Brush and shrubs grow along the high, steep banks.

Flowing through Patton Valley, the upper Tualatin is usually open to the sun, but near Gaston it acquires a canopy of Oregon Ash (Fraxinus Zatifolia), black cottonwood (Populus trichocarpa), big leaf maple (Acer macrophyllum), willow (Salix spp.), and other riparian species. Below Gaston the Tualatin River is partially canopied by numerous shrub and tree species, but at Hillsboro the canopy opens 
TABLE II

LOCATION OF SAMPLING STATIONS, TRIBUTARIES, AND OUTFALI:S AIONG THE MIDDLE COURSE

OF THE TUALATIN RIVER

RIVER MILE

62.3

60.2

58.8

56.8

55.2

51.5

44.8

44.4

44.3

38.4

38.1

$38.1(0.8)$

33.3
LOCATION

Gaston (Sampling Station)

Mouth of Scoggin Creek

Dilley (Sampling Station)

Mouth of Gales Creek

Outfall of Forest Grove Sewage Treatment Plant

Cornelius (Sampling Station)

- Mouth of Dairy Creek

Hillsboro (Sampling Station)

Outfall of Hillsboro

Sewage Treatment Plant

Rood Road (Sampling Station)

Mouth of Rock Creek

Rock Creek (Sampling Station)

Farmington (Sampling Station) at Harris Bridge. 
and fails to reach the center of the channel. From Hillsboro downstream, sunlight reaches the water for at least part of the day.

Agriculture is minimal, and there are no municipal sewage treatment plants above Gaston. For these reasons, and because Gaston is at the head of the floodplain of the mainstem Tualatin it marks a good place to start an analysis of the human impact on the river.

The US Geolcgical Survey operates a stream flow gauge above Gaston, slightly upstream from the sampling station.

$\underline{\text { Scoggin }}$ Creek

Scoggin Creek enters the middle Tualatin River at RM 60.2. It is a small, forest stream flowing east from the Coast Range through a small, narrow floodplain. Scoggin Creek and the mainstrem Tualatin are affected by Stimson Forest Fiber Products Mill and its adjacent log pond. In the past, agriculture has been the main use of the land on the floor of Scoggin Valley, but when the Scoggin Dam was completed in 1974, the farmlands were inundated.

\section{Dilley}

Dilley, the sampling station at RM 58.8 is on the north shore of the river, west of the Springhill Road Bridge. The shore is a long, broad, sandy beach sloping down to the water and a sandy streambed. This is one of the very few beach 
areas along the whole river.

Upstream from the Dilley sampling station, the city of Gaston has a secondary sewage treatment plant discharging $0.005 \mathrm{~m}^{3} / \mathrm{s}$ ( 0.125 million gallons per day)(mgd) into the Tualatin River. Dilley is also downstream from Scoggin Creek, so the impact of that tributary can be ascertained. There is a US Geological Survey stream flow gauge at this station.

\section{Gales Creek}

Gales Creek originates in the Coast Range and flows southwest to enter the middle course of the Tualatin River at RM 56.8. Upper Gales Creek has a rocky streambed, but the lower reaches have an alluvial bottom.

Many diversified, small farms lie along the narrow floodplain of Gales Creek. There is one small village, Gales Creek, in the valley.

Cornelius

The Cornelius sampling station at RM 51.5 is on the east bank of the river, south of the Golf Course Road Bridge and south of the small town of Cornelius. The streambed at Cornelius is a finer sand that at Gaston and has more silt in the mixture. Rip-rap rocks stabilize the east bank of the river. 
The bottom of the river here is strewn with junk: old porcelain toilets, bottles, cans, pieces of household appliances and furniture, old car parts, deer bones, and other relics of human society. The age of many of these articles shows that this bridge has been used as a dump for many years, which is true of most of the Tualatin River bridge crossings.

The sampling station at Cornelius is downstream from Gales Creek and the $0.11 \mathrm{~m}^{3} / \mathrm{s}$ (2.5 $\left.\mathrm{mgd}\right)$ sewage treatment plant for the city of Forest Grove.

Dairy-McKay Creek Complex

The East Fork and West Fork of Dairy Creek flow south, unite and continue southwestward to merge with south flowing Mckay Creek. Then as Dairy Creek they join the Tualatin at RM 44.8. These three creeks drain over $518 \mathrm{~km}^{2}\left(200 \mathrm{mi}^{2}\right)$ of timbered watershed and diversified farming.

The towns of Banks, North Plains and Hillsboro are in the drainage basins of these creeks. Banks has a secondary sewage treatment plant of $0.06 \mathrm{~m}^{3} / \mathrm{s}(0.14 \mathrm{mgd})$ which is $16 \mathrm{~km}$ (10 mi) upstream from the Tualatin on the West Fork of Dairy Creek. Houses in North Plains have septic tanks.

These tributaries have US Geological Survey stream flow gauges which were reactivated during this study.

\section{Hillsboro}

The Hillsboro sampling station is on the north side of 
the river and east of the bridge where Highway 219 crosses the Tualatin River at RM 44.4 .

The river at the Hillsboro Station has a bed of hard, blue clays and banks of sandy silt.

Winter high waters overflow the main channels and cover extensive areas of the floodplain, especially at Hillsboro where a part of the floodplain known as Jackson Bottom often gets floodwaters over $1.6 \mathrm{~km}$ ( $1 \mathrm{mi}$ ) wide and $3 \mathrm{~m}$ (10 ft) deep.

The Hillsboro Station is downstream from the Cornelius sewage treatment plant $0.11 \mathrm{~m}^{3} / \mathrm{s}$ (9.25 mgd) and Dairy Creek and its agriculture.

The comparison of this station with Rood Road, the next sampling station downstream reveals the impact of the city of Hillsboro upon the Tualatin.

$\underline{\text { Rood Road }}$

The Rood Road sampling station is west of the Rood Road Bridge and on the north side of the river at RM 38.4 .

A grey, compact, very fine clay, which is extremely slippery to walk on, makes up the river bed at this station. It is part of the parent bed material rather than being annually deposited.

There is a small, temporary dam upstream from this station to supply water height for the irrigation pumps for a dairy on the south side of the river. The impoundment 
does not change the flow volume, but it does allow a pond habitat which can affect the aquatic organisms found at this station.

Samples were taken from the north side of the river to avoid any bias from the liquified animal wastes from the dairy on the south side. These liquified, animal wastes are irrigated on pastures in the summer and discharged into the river in the winter.

Sometimes the river at Rood Road reflects the operation of the Hillsboro sewage treatment plant of $0.11 \mathrm{~m}^{3} / \mathrm{s}(2.5$ mgd) above Rood Road. There are patches of foam on the water and chunks of cannery wastes in the water which is sometimes the grey color of sewage effluents.

Because of summer irrigation demands, Rood Road Station usually has the lowest summer flow along the river, even to extended periods of time with zero flow.

$\underline{\text { Rock } \text { Creek }}$

Rock Creek joins the middle course of the Tualatin River at RM 38.1 , about $0.5 \mathrm{~km}(0.3 \mathrm{mi})$ downstream from the Rood Road Bridge. Rock Creek drains the Tualatin Mountains, small hills on the northeast side of the Tualatin Basin. Beaverton Creek, the main tributary of Rock Creek, originates in the West Hills of Portland near the town of Beaverton and flows west into Rock Creek. 
The sampling station on Rock Creek was at the River Road Bridge $1.3 \mathrm{~km}(0.8 \mathrm{mi})$ above the mouth of Rock Creek. This was necessary in order to be upstream from the effluents from the second Hillsboro sewage treatment plant of $5.5 \times$ $10^{-2} \mathrm{~m}^{3} / \mathrm{s}(1.25 \mathrm{mgd})$, and because it was the nearest point of public access to the creek above its mouth.

In summer the flow of Rock Creek is more than $95 \%$ effluent from the many sewage treatment plants that serve the highly urbanized areas on the west side of Portland Hills, and the towns of Beaverton and Aloha. The water from Rock Creek in the summer looks like syrup when compared with regular river water from the Tualatin. Natural flows may be absent from Rock Creek in the driest summers.

\section{Farmington}

Farmington, the last sampling station, was included to indicate conditions in the lower Tualatin River and to provide a contrast with the middle Tualatin. Harris Bridge, the sampling site on Farmington Road, is at RM 33.3. The river here is more biologically and chemically allied to the lower river, but has flow characteristics of the middle river.

The streambed at Farmington consists of very fine, alluvial silts and clays that are the products of deposition. The US Geological Survey has a flow gauge at Farmington and has marked the length of the bridge at $1.5 \mathrm{~m}$ (5 ft) 
intervals which makes measurement of the river width for streamflow calculations easier. Consequently, a consistant effort to calculate the streamflow at Farmington was made.

In late summer, the river appears to be a slow, meandering, highly eutrophic body of water markedly colored with algae and detritus. In the winter the water quality of the river at Farmington Station is improved because of increased flow.

Figures 5 through 14 depict typical scenes along the river in the summer and in the winter floods.

\section{GEOLOGICAL DESCRIPTION}

The slopes of the Coast Range mountains which establish the western boundary of the Tualatin Basin are underlain by igneous and sedimentary rocks of Eocene age. The oldest rocks in the basin are outcroppings of Eocene basalt south of Gales Creek and west of Cherry Grove on the higher slopes of the foothills. These volcanic rocks are overlain by Eocene sedimentary shales, claystones, sandstones, and siltstones.

Other basaltic lava flows, possibly of Eocene origin, form the strike ridge reefs, or basaltic dikes, in the Tualatin River streambed 4 to $6.5 \mathrm{~km}$ (2.5 to $4 \mathrm{mi}$ ) above Oregon City.

0ligocene and, perhaps, Miocene sedimentary rocks, sandstones, and shales occur in a belt along some of the 


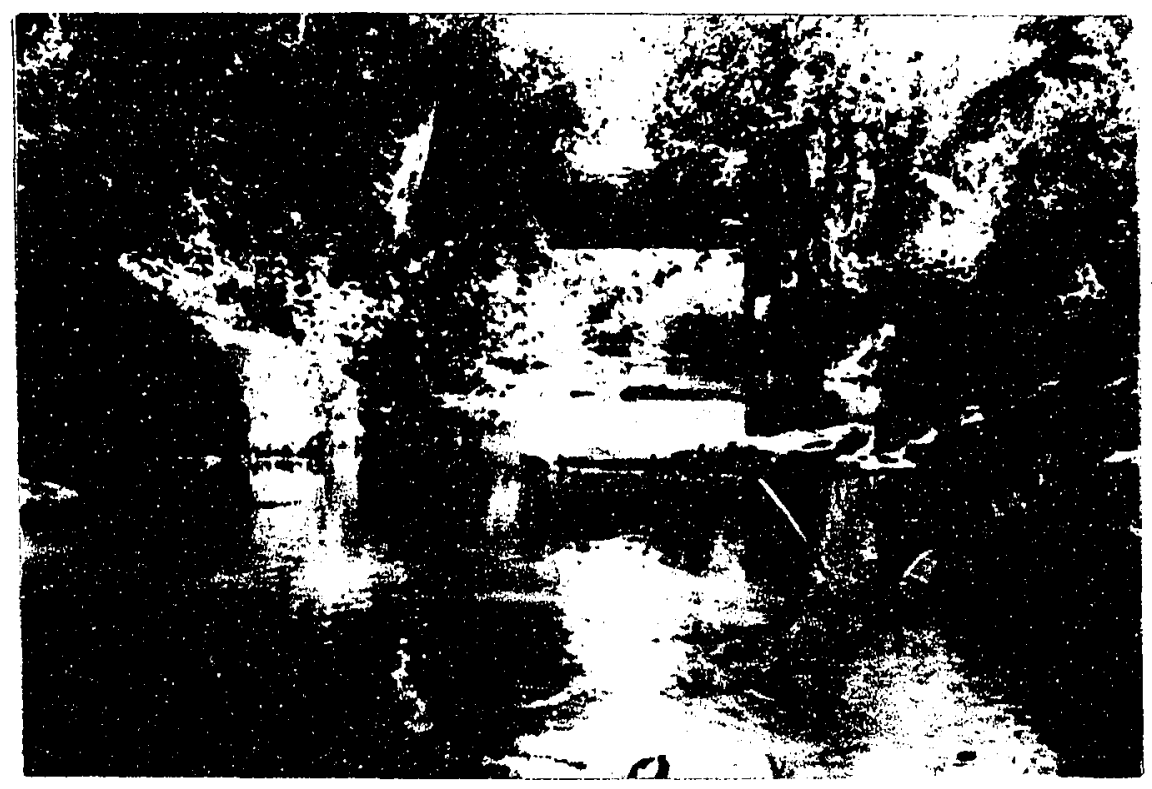

Figure 5. Gaston, the upstream sampling station, summer 1973. Note the tree canopy and the shallow flow of water.

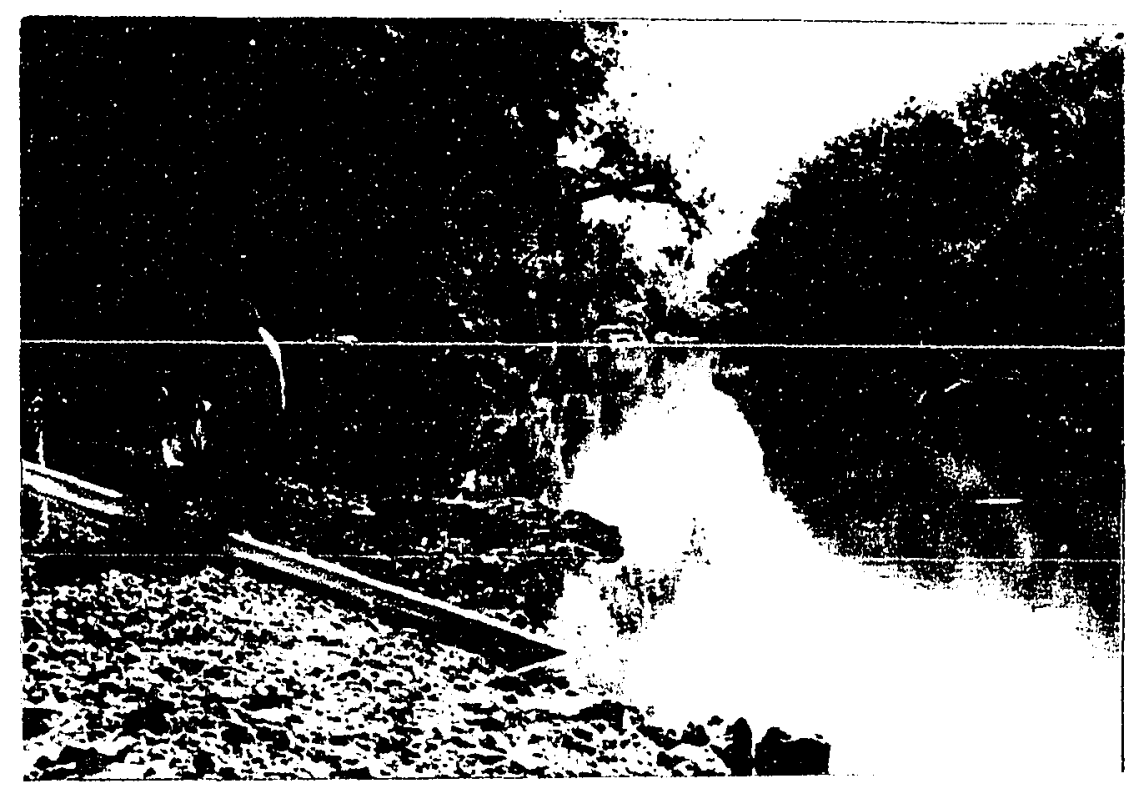

Figure 6. Farmington, the last sampling station downstream, summer 1973. The pipe is from an irrigation pump. Note the similarity between the two extremes of the middle course of the Tualatin River. 


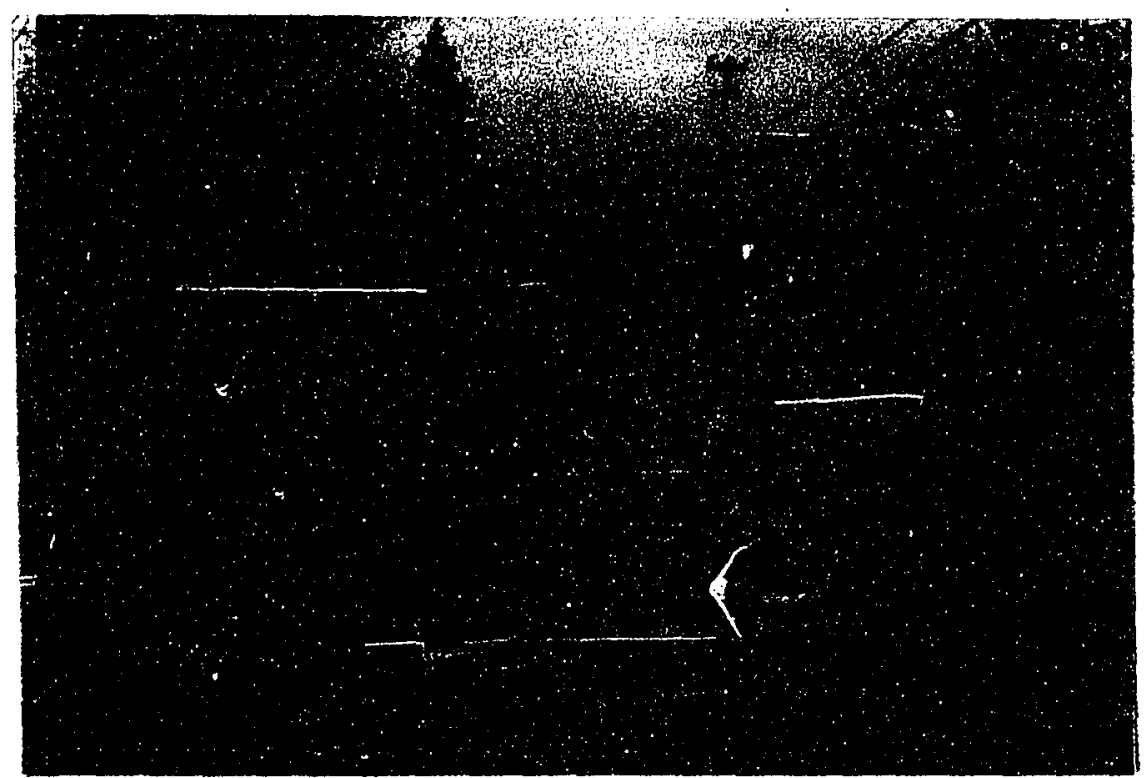

Figure 7. Hillsboro sampling station: Oregon Highway 219 bridge during the flood of 1972 .

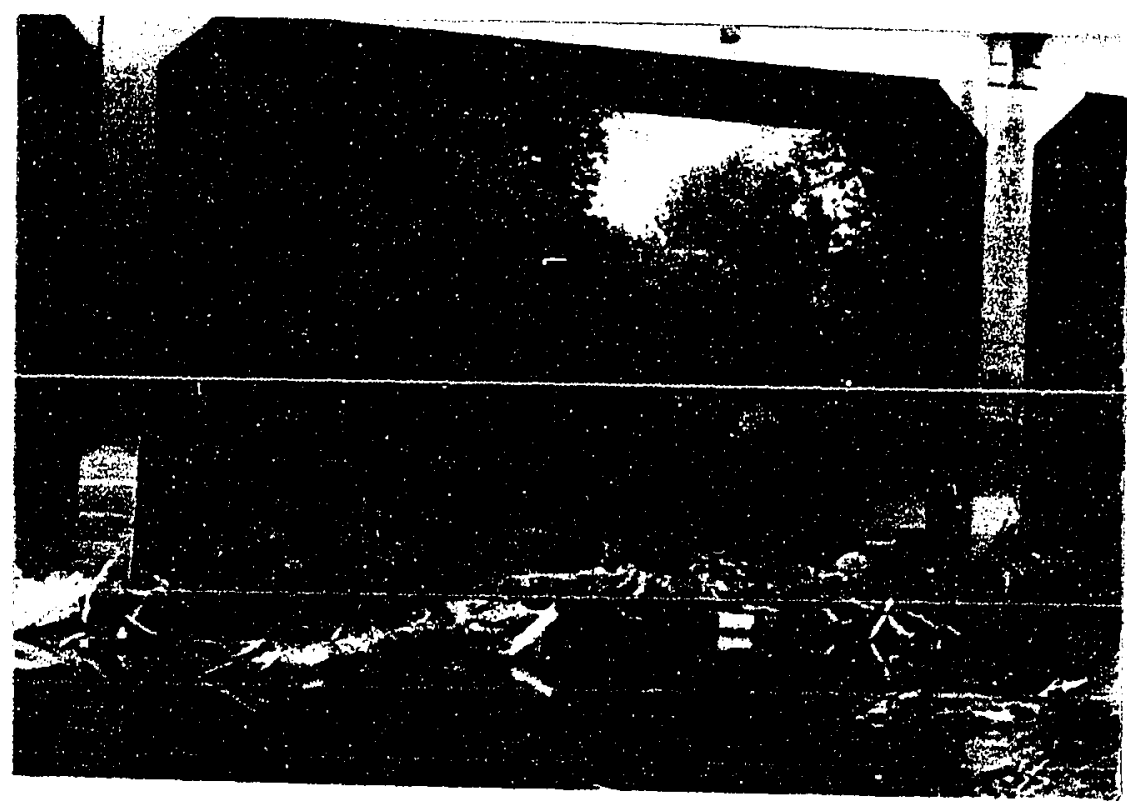

Figure 8. Hillsboro sampling station: Oregon Highway 219 bridge, summer $1973^{\circ}$ at zero flow. The bottom of the bridge deck is about $10 \mathrm{~m} \mathrm{(} 30 \mathrm{ft}$ ) above the streambed. Compare this picture with Figure 7 . 


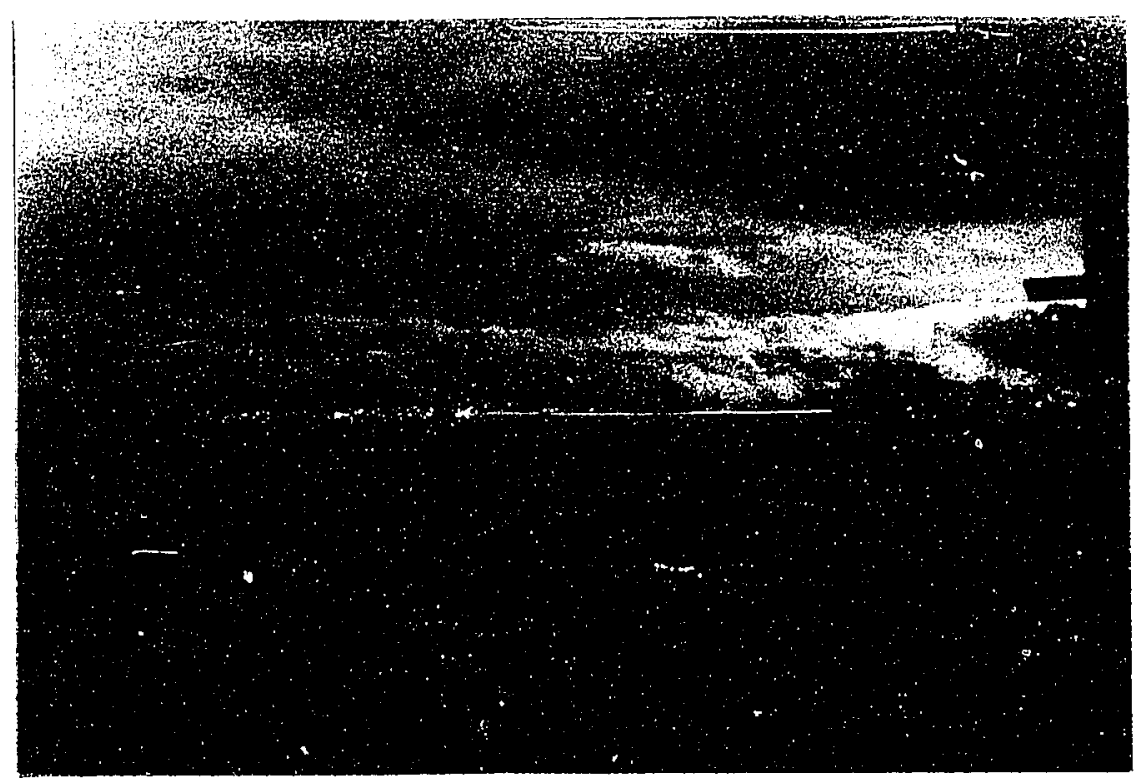

Figure 9. The Industrial Sewer Farm for the HillsboroWestside sewage treatment plant at floodstage, 1972. The trees in the distance border the Tualatin River about $0.6 \mathrm{~km}$ ( $1 \mathrm{mi}$ ) away.

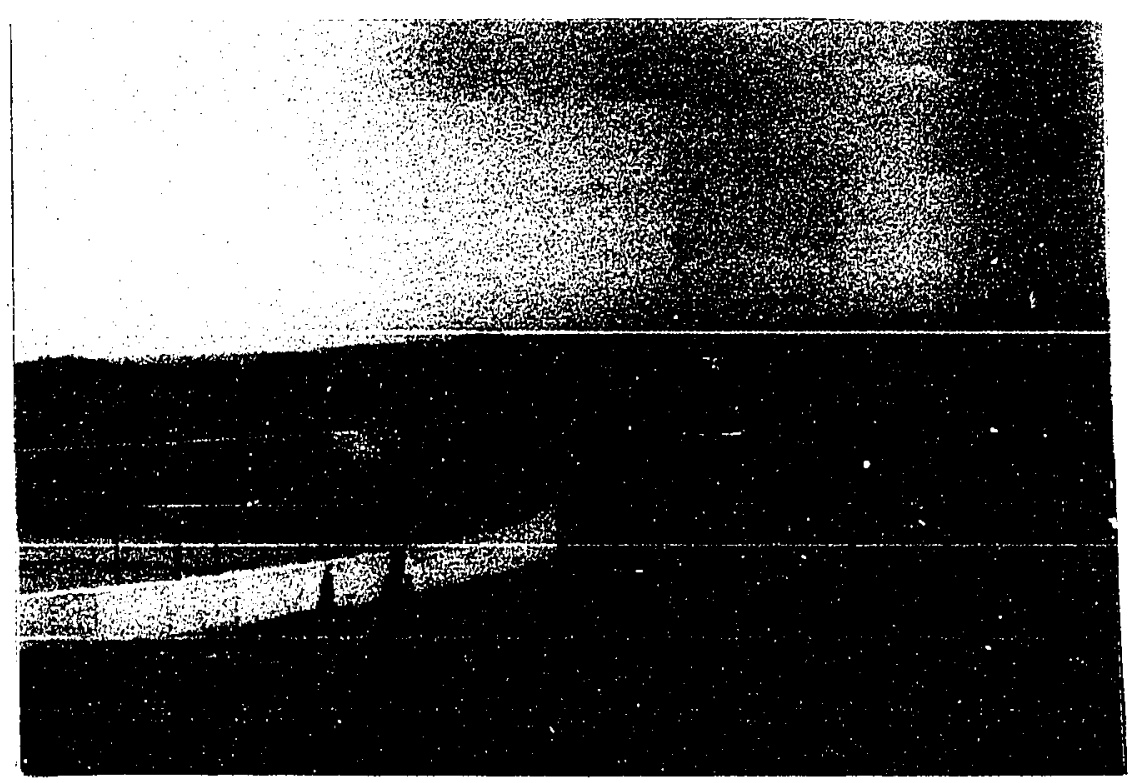

Figure 10. The Industrial Sewer Farm for the HillsboroWestside sewage treatment plant, summer 1973. Compare this picture with Figure 9. 


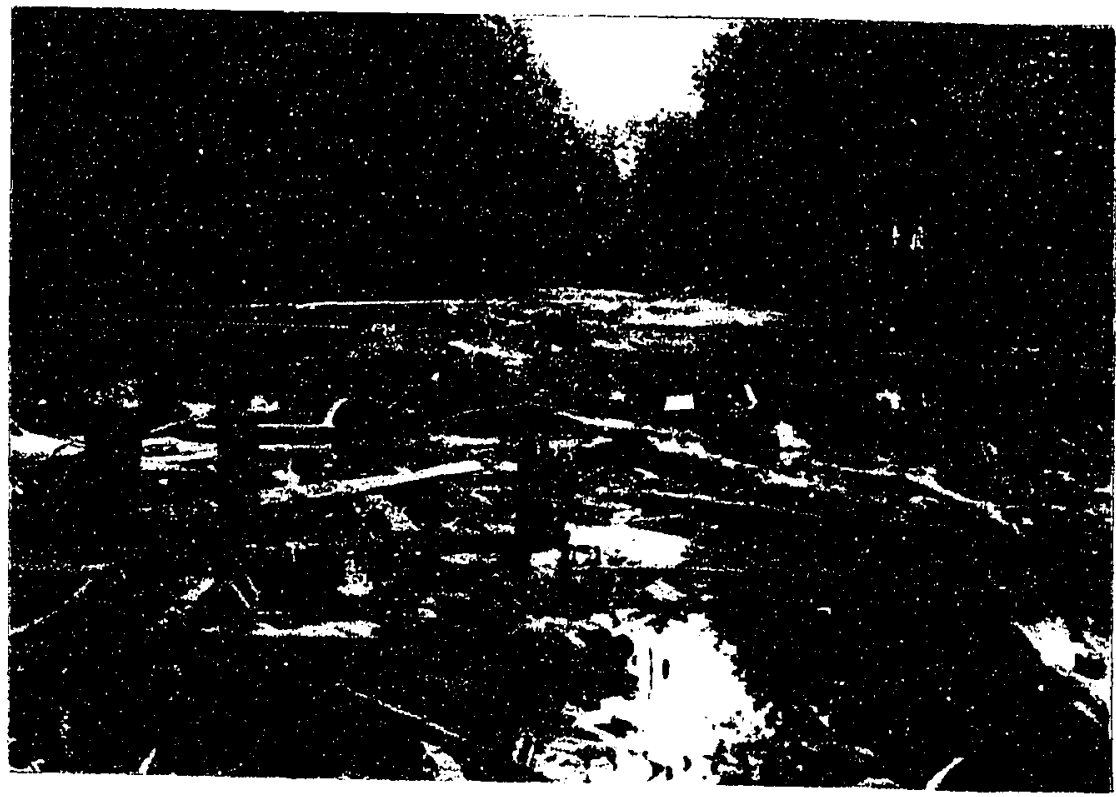

Figure 11. Rood Road Station: looking downstream at zero flow, summer 1973. Note the clay dike across the streambed at the top of the picture blocking any flow.

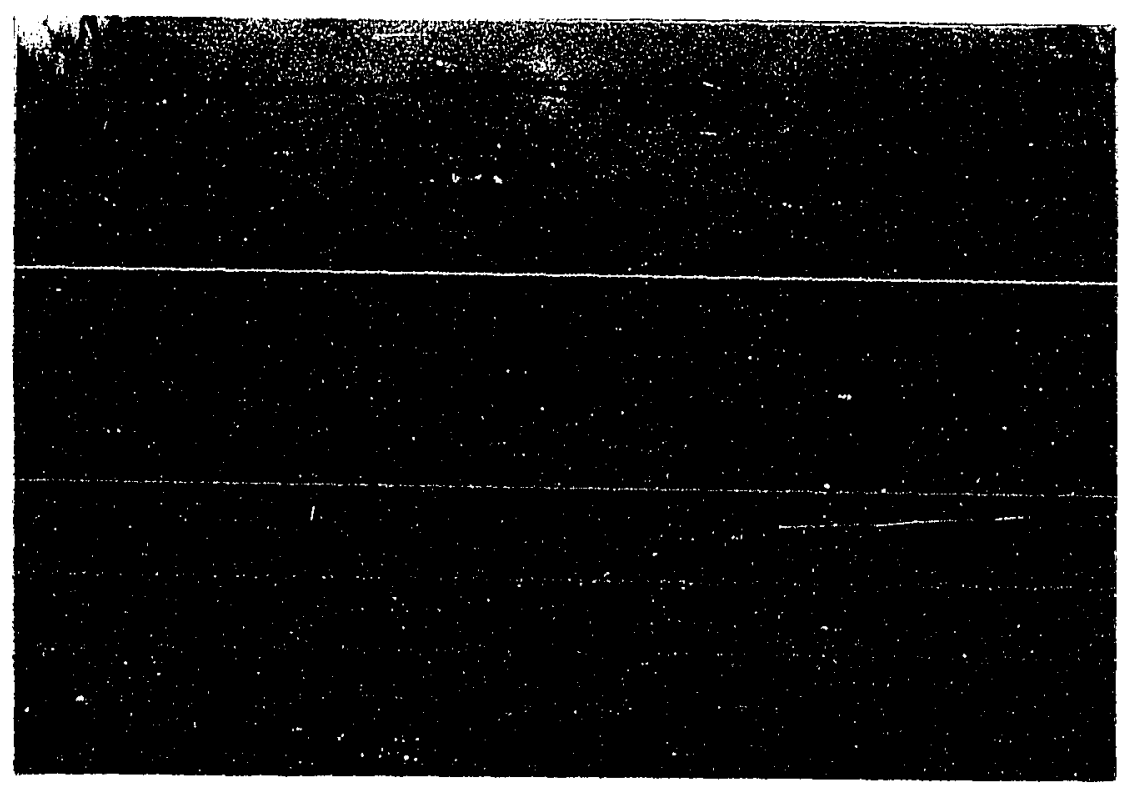

Figure 12. Rood Road Station: looking downstream at flood time, 1972 . 


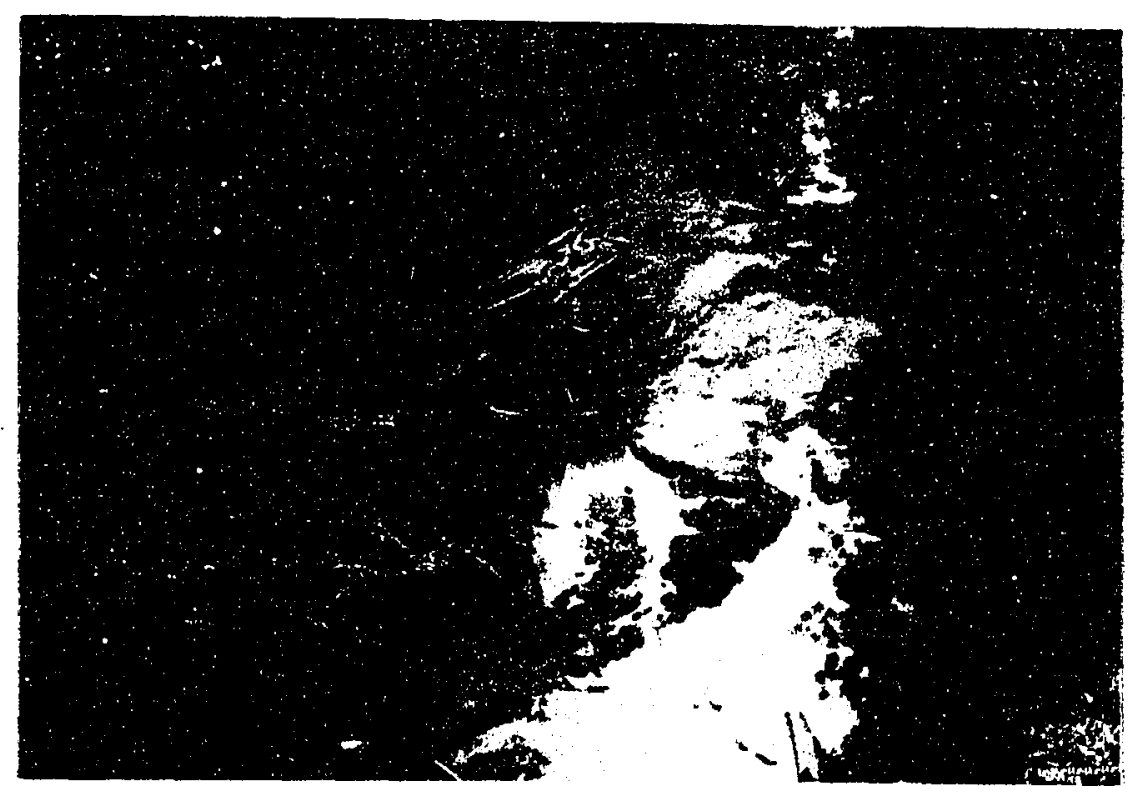

Figure 13. Rood Road Station: an overhead view of the clay dike across the channel, summer 1973.

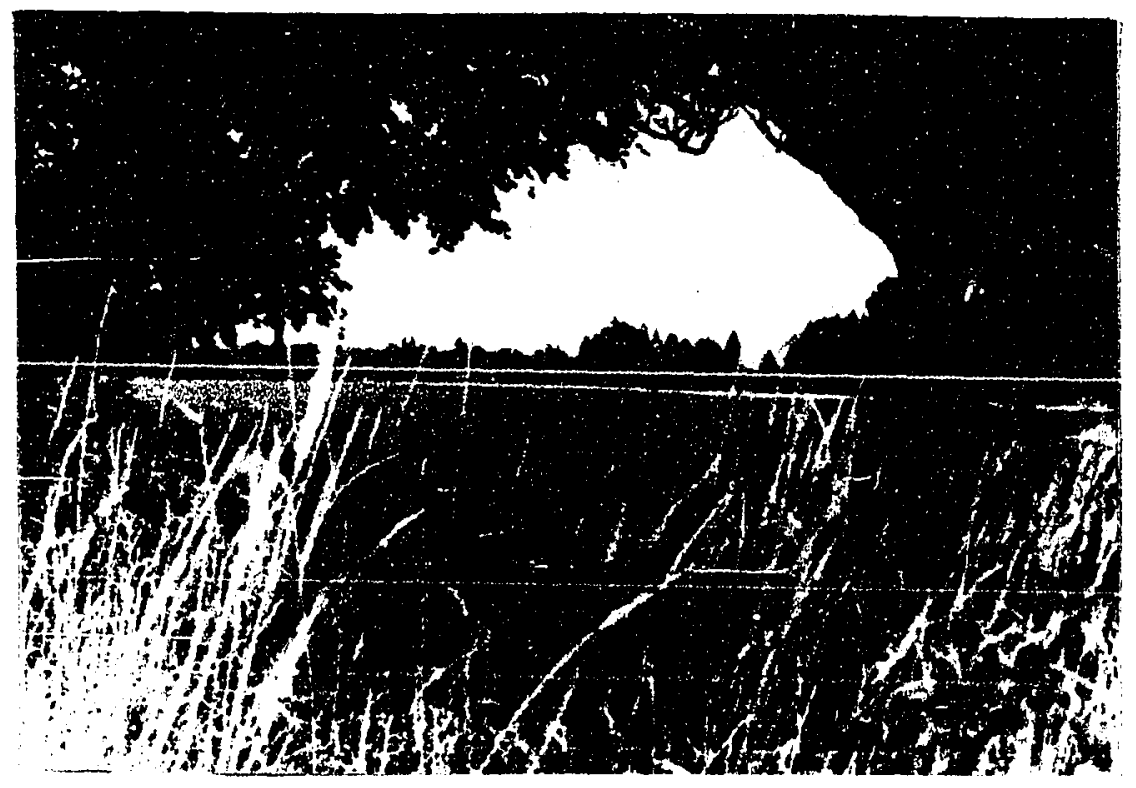

Figure 14. Diversified agriculture on the floodplain at Connelius. In the winter this area is flooded to the road bank. 
hills from Gaston to Forest Grove, along the headwaters of Dairy Creek, and in parts of the McKay Creek Canyon. These sediments are predominantly marine with some brackish and freshwater deposits.

Overlying these Oligocene and Miocene sedimentary rocks are a series of lava flows known collectively as Columbia River Basalts. Columbia River Basalt outcroppings ring the valley on the lower slopes, and form the tops and slopes of the Chehalem Mountains to the south, Cooper and Pete's Mountains and the highest ridges of the Portland Hills to the east. The Columbia River Basalt on the upland slopes is moderately eroded and deeply weathered to residual lateritic soils, which form some of the distinctive red soils of the area. In some places the laterites form important low-grade deposits of aluminum ore.

The Troutdale Formation, a deposit of semi-consolidated silt, clay, and sand overlies the Columbia River Basalt. The Troutdale Formation was deposited in the Tualatin Basin by freshwater; no marine deposits are represented.

In some areas, another volcanic extrusive lava, the Boring Lava, covers the Troutdale Formation. This layer of lava extruded from volcanic vents in the West Hills of Pontland and is confined to the upper slopes of the West Hi.lis, which form the eastern boundary of the basin.

Tertiary and Quaternary alluvial sediments formed the flat valley floor. These deef sedimentary layers are largely 
of clay and silt with some sand beds at separated intervals. They were probably deposited entirely by freshwater. The present floodplains have areas of recent alluvium which make up some deposits on the present floodplain as well as some pockets of water-borne debris. This young alluvium is still being deposited in many areas and is a thin layer of very fine silts, clays, fine sands, and peaty material.

The foregoing geological description is based on the work of Hart and Newcomb (1965). 


\section{CHAPTER III}

\section{HISTORICAL BACKGROUND}

Early 19th Century accounts of Indians in the Tualatin River Basin relate to the Tualatins, or Atfalati, as they called themselves. These were a group of tribes or small migrating communities that wintered at camping grounds at Lake Wapato near the present town of Gaston, Oregon. Lake Wapato was formed by the Tualatin River floods and was regulated in depth by the height of the flow of the river. The area is now known unpoetically as the "Gaston Onion Flats". The Kalapuya Texts (Gatschet et al. 1945), the best account of Tualatin Indian life, were dictated in the 1930's by the old Indians of the Atfalati. References to the river are infrequent so one can infer that uses of the Tualatin River were minimal.

The Atfalati ranged far in pursuit of food, both on foot and later on horseback, but Lake Wapato and other swampy areas in the Tualatin drainage basin provided many of the aquatic foods for these Indians. Winter camps were usually near an availabile supply of Wapato or arrowhead, Sagittaria latifolia, as well as camus or quamash, Camassia Leichtliner and $C$ : quamash, and other less important roots and bulbs.

Fishing in the Tualatin River was limited. Indiginous fish were cutthroat trout, Salmo clarki; large scale 
suckers, Cațostomus macrocheilus; red-sided shiners, Richardsonius balteatus; and in the headwaters, dace, Rhinichthys spp., and sculpins, Cottus spp.' (Thompson et al. 1966).

There is no written historical record concerning salmon in the Tualatin River. Melville Jacobs, who co-edited The Kalapuya Texts, was told by the Indians that there were no salmon above the Oregon City Falls on the Willamette River before the fish ladders were built there by the settlers. This would have meant no anadromous salmonids in the Tualatin River system (Benson 1973). However, Thompson et al. (1966) state that the falls were only a restriction but not a complete barrier to salmon, steelhead, and lamprey migrations. At any rate the Indians speak of getting their salmon at the falls at Oregon City and in the Columbia River (Gatschet et al. 1945).

In The Kalapuya Texts the only reference to canoes is as a cooking vessel or utensil. The river does not seem to have been used by the Indians for transportation by boats of any kind. Robert Benson (1973 pers. comm.) never found a reference to the Atfalati using canoes.

Apparently Hudson Bay Company fur traders named Dairy Creek, a tributary of the Tualatin, for the dairy they had near Centerville on that creek (McArthur 1943). By 1841 the fur trade diminished and settlers began to populate the Tualatin Valley. By 1845, when the first official census 
was taken, there were 775 people residing there: 219 adult males, 159 adult females, and 397 children (Washington County Archives). The Tualatin Basin contained the Tualatin Plains, one of the few areas of natural prairie in the Northwest (Benson 1967). This meant rich farmland without the need for clearing trees.

The Indians may not have used the river for transportation, but settlers from the eastern United States were used to boats, barges, and steamers. On 29 January 1856 the Tualatin River Transportation and Navigation Company was incorporated and required by the act of incorporation to keep the Tualatin River clear of obstructions (Miller 1930). Captain Chris Sweitzer and Captain George H. Pease in 1858 brought the streamer Hoosier, and operated it on the Tualatin between Hillsboro and Forest Grove. The Hoosier made some trips up the river to Harris Bridge, but could go no further upstream because of a dam and log jam above Harris Bridge. The Phillip Harris land claim is $3 / 4 \mathrm{mi}$ south of Farmington and is the probable location of this old bridge (Miller 1930). The present bridge across the Tualatin at Farmington is also known as the Harris Bridge and the pilings from the old steamer landing can be seen downstream. The steamer Hoosier carried several loads of wheat to Moore's Mill.

These same two river captains then took a contract Irom the Tualatin Improvement Company to clear logs and 
drifts so that the river could be navigated to or near Forest Grove. This contract was for $\$ 1,500$, with $\$ 500$ to be paid when the steamer blew its whistle at or near Hillsboro. In December 1858, they blew the whistle near Hillsboro, but got no money and so on Christmas Eve they quit. The Hoosier was. then taken to the Willamette River (Miller 1930).

Attempts to keep the Tualatin navigable continued. By 1869 the Onward with a crew of three was the only boat operating. This steamer had a 60 mile journey on the twisting river between Colfax (near Lake Oswego) and Emericks's landing (south of Cornelius), leaving Colfax each Thursday and Forest Grove on Monday. Passengers had to travel from Portiand to Colfax by the Willamette River steamer, take another steamer across Lake Oswego and then go by rail to Colfax before boarding the onward the next morning. The 22 July 1869 Oregonian published notice of the Onward's cessation due to low water and lack of cargo; it was able to resume service on 10 November 1869.

The opening of Canyon Road, which allowed the residents of the Tualatin River basin easier access (by stage coach and wagons over a plank road) to Portland and its markets, spelled the doom of river navigation. Thus, the population of this small valley grew with agriculture as its economic base. There were 30,275 residents in Washington County in 1930 ; 39,194 in $1940 ; 61,269$ in 1950 ; and by 1970 there were 157,920 (Bel1 1971). This large increase after World War II 
was due to the construction of Oregon State Highway 25, the Sunset Highway, which made it feasible for residents of Washington County to commute to Portland to work.

In 1936, when the population of Hillsboro was about 3,500 , the first secondary sewage treatment plant on the Tualatin River was built. Domestic waste treatment plants were by then necessary to "clean-up the Tualatin". In 1967 this plant, which was designed to treat $2.2 \times 10^{-2} \mathrm{~m}^{3} / \mathrm{s}$ ( $0.5 \mathrm{mgd})$ for 1,400 people, was grossly overloaded and discharging an average $3.5 \times 10^{-2} \mathrm{~m}^{3} / \mathrm{s}(0.8 \mathrm{mgd})$ with a biochemical oxygen demand of over $200 \mathrm{mg} / \mathrm{l}$ (OSSA 1967).

In 1972 this plant was finally upgraded to process $0.11 \mathrm{~m}^{3} / \mathrm{s}(2.5 \mathrm{mgd})$.

This history of sewage treatment in Hillsboro is representative of other communities in the valley. By 1972 there were 15 sewage treatment facilities on the Tualatin River or its tributaries above Farmington.

In the late 1930's farmers of the area began an intensive campaign to gain a water storage dam to provide irrigation water throughout the dry sumners. The Tualatin River and its tributaries did not have a sufficient summer flow for irrigation. This project was finally approved in 1966, and almost 40 years after the idea of the dam was initiated, construction on the Scoggin Creek Dam began in 1972. The reservoir behind this dem (completed in 1974) is expected to provide waten for irrigation of 6900 hectares $(17,000$ acres), 
$17.3 \times 10^{6} \mathrm{~m}^{3}(14,000 \mathrm{ac}-\mathrm{ft})$ of water for municipal and industrial supplies and additional water for stream life and water quality (USBR 1963; STR 1969).

By 1970 the eastern half of the basin had become part of the suburban sprawl of the metropolitan Portland area. The western half of the valley was still predominately agricultural. There were about 6900 hectares $(17,000$ acres) of irrigated croplands in 1973, not including permanent pasture lands some of which are also irrigated. The irrigated croplands grew specialty crops of various kinds of berries, especially strawberries; and also corn, alfalfa and hay, clover, potatoes, and row-crop vegetables. Washington County (Tualatin Valley) gross farm income from both dryland and irrigated crops was $\$ 41,927,000$ for 1973 . One-fourth of this income was derived from sale of $31.8,000$ cattle, poultry, sheep and horses, all consumptive water users (WCAES 1974). This figure does not include the animals, such as dairy cows, which were not sold, yet were a vital part of the economy and were consumers of water.

A survey by the Oregon State Game Commission of fish in the Tualatin River drainage basin showed that in addition to the indigenous fish that the Indians used, there are a number of introduced species which have replaced the native species in importance for fishing. During the winters and eariy spring there are coho salmon, oncorhynchus kisutch; winter steelhead, Salmo gairdneri; hatchery grown rainbow 
trout, S. gairdneri; and cutthroat trout, s. clarki. Warm water species include largmouth bass, Micropterus salmoides; bullhead catfish, Ictalurus spp.; bluegills, Lepomis maerochirus; pumpkin seeds, L. gibbosus; carp, Cyprinus carpio; and crappies, Pomoxis spp. (Thompson et al. 1966). There is no commercial fishing on the Tualatin River.

In March 1972, under the 3 March 1889 River and Harbors Act of the United States, the Tualatin River was declared a navigable stream to the mouth of Gales Creek by the US Army Corps of Engineers. This action is a direct contradiction to the 1895 statement of the US Army Corps of Engineers which pronounced the Tualatin River and its tributaries unsafe for navigation (Forest Grove News Times 30 March 1972). The March 1972 declaration related to water pollution control, not navigation. However, subsequent to this declaration the federal authority for water quality control of the Tualatin River has been religated to the Oregon Department of Environmental Quality.

At the present time (1974) water supply has become a critical issue for both farmers and municipalities in the Tualatin River Basin. There are plans being formulated for other water-storage facilities on other tributaries of the river and on the mainstem Tualatin above Gaston. Decisions to be made in the near future will have far-reaching effects on uses of water from the Tualatin River and its tributaries. 
CHAPTER IV

METHODS AND MATERIALS

Samples for analysis were collected twice a day at intervals of 2,3 , or 4 weeks. The longer intervals occurred during the winter when the river was iced or flooded and biologically more stable.

Two sample periods per day were chosen to assess the relative effects of respiration and photosynthesis. The first set of samples, to ascertain the effects of darkness, was collected before sunrise. The time of sunrise was determined from daily US Weather Bureau reports. Grab samples for dissolved oxygen, biochemical oxygen demand, and basic chemical analyses were collected. At the same time $\mathrm{pH}$, air and water temperatures, weather conditions, and the time of day were recorded.

Dissolved oxygen and biochemical oxygen demand samples were collected in $300-\mathrm{ml}$ wheaton glass bottles fitted with ground glass stoppers. Water for all other tests was collected in 2-liter, wide mouth, Nalgene plastic containers. To check on the effect of photosynthesis, a second set of samples was collected starting between 1200 and 1400 PST. Samples were collected in the same way as in the early morning except that plankton samples were also taken. Measurements for flow calculations were taken from the Farmington Bridge in all seasons, and at other stations in July and 
August. In the field when air temperatures were above 15C, the samples were kept in an ice chest. At all times they were protected from heat and sunlight.

In the laboratory all water samples were stored in the dark at 6C until analyses were completed. Plankton samples were stored in the dark at 6C until they could be passed through Millipore filters.

Temperature

Air and water temperatures were measured with a Taylor pocket mercury thermometer $(-15 \mathrm{C}$ to $105 \mathrm{C})$. Water temperatures were taken with the thermometer held $15 \mathrm{~cm}$ ( 6 in) below the surface of the water and out of direct sunlight. Air temperatures were read with a dry thenmometer in the shade near the edge of the water and about $1 \mathrm{~m}$ ( $3 \mathrm{ft}$ ) above ground. All readings are to the nearest degree after time for equilibrium.

$\underline{\mathrm{pH}}$

A Corning portable $\mathrm{pH}$ meter (Model 6) recorded $\mathrm{pH}$ to the nearest tenth of a pH unit. The meter was also used to titrate for alkalinity values. Field readings were obtained from small grab samples collected in a beaker well-washed with river water. Corning $\mathrm{pH} 7.00( \pm 0.01$ at $25 \mathrm{C})$ Buffer was used to calibrate the meter before each use. 
Dissolved oxygen

The test for dissolved oxygen-azide modification, as given in Standard Methods of Water and Wastewater Determination (hereafter refered to as Standard Methods)(APHA 1971), was used to estimate dissolved oxygen concentrations. Wheaton, glass, BOD bottles were positioned so that river water entered the bottles about $15 \mathrm{~cm}$ ( 6 in) below the surface. Samples were chemicalyy fixed in the field and titrations were made within 6 hours.

Biochemical oxygen demand (BOD)

Except for some Rock Creek and Farmington Station samples, which required dilution, $B O D$ was determined from 300-ml samples in Wheaton glass BOD bottles. BOD samples were collected at the same time in the same way as dissolved oxygen samples. Procedures described in Standard Methods (APHA 197I) were used to analyse the BOD in incubated samples held in darkness at $20 \mathrm{C}$ for 5 days. Each bottle was sealed with distilled water and capped with a piece of aluminum foil tightly wrapped over the stopper and neck to prevent evaporation during incubation.

\section{Nitrate-nitrogen}

Samples of $25.0 \mathrm{ml}$ or suitable aliquots were measured colorimetrically for nitrate-nitrogen and nitrite-nitrogen on a DC-DR-"B" series Hach Kit colorimeter (Hach Chemical 
Company, Ames, Iowa) having an accuracy of $\pm 2 \%$. The cadmium reduction method was used according to the directions provided by the manufacturer. Although the values are listed as nitrate-nitrogen, actually they include both nitrate- and nitrite-nitrogen. A blank test of deionized-distilled water and the reagent produced a value of $0.02 \mathrm{mg} / \mathrm{l}$ nitrate-nitrogen, which is included in the recorded value. All water samples were tested for nitrate-nitrogen immediately after each sampling time.

Ammonium-nitrogen

Ammonium-nitrogen was measured using the Nessler's Reagent method as given in Standard Methods (APHA 1971) on the DC-DR-"B" series Hach Kit. Samples of $25.0 \mathrm{ml}$ or suitable aliquots were used without distillation. All samples were tested immediately us returning from the field. Blanks were prepared with Nessler's Reagent in deionizeddistilled water and used to calibrate the Hach Kit colori-: meter.

\section{Alkalinity}

The electropotentiometer method described in standard Methods (APHA 1971) was used to measure alkalinity. A 100$\mathrm{ml}$ sample of water was titrated with $0.02 \mathrm{~N} \mathrm{HCl}$ to $\mathrm{pH} 4.5$ (volume $A$ ) on the $\mathrm{pH}$ meter and then further titrated to $\mathrm{pH} 4.2$ (volume B). The volume of $\mathrm{HCl}$ at each $\mathrm{pH}$ was recorded 
and the following formula applied:

Alkalinity in $\mathrm{mg} / \mathrm{l}$ as $\mathrm{CaCO}_{3}=\frac{(2 \mathrm{~A}-\mathrm{B})(\mathrm{N})(50,000)}{\mathrm{ml} \text { sample }}$ where $N$ = normality of acid used.

Before use all glassware was washed 5 times in an additional amount of the sample of river water being analyzed.

Phosphate

The DC-DR-"B" series Hach Kit was used for the polyphosphate analysis. Samples of $25.0 \mathrm{ml}$ or suitable aliquots were boiled with acidified amnonium molybdate (Hach Company prepared reagent) and cooled before Hach prepackaged stannous chloride was added. After color development the samples were analyzed with the colorimeter. The colorimeter was calibrated with a blank containing a water sample (unboiled) and the ammonium molybdate reagent.

All water used for polyphosphate determinations were stored in Nalgene containers in the dark at 6C. These containers were routinely washed with phosphate-free detergent and then with $1.3 \mathrm{~N} \mathrm{HCl}(1: 9 \mathrm{HCl})$, then rinsed three times with deionized-distilled water and three times with river water before use.

Ortho-phosphate was measured in unboiled water samples. using the Hach Kit manufacturer's instructions.

All glassware used in all phosphate analyses was washed with phosphate-free detergent, acid washed, and rinsed with both deionized-distilled and river water. Between analyses 
deionized-distilled water was kept in the glassware to preclude phosphate adsorption on the pyrex flasks and graduated cylinders. Ortho-phosphate analysis of the deionized-distilled water stored in the flasks for 3 weeks showed no phosphate.

Turbidity

The DC-DR-"B" series Hach Kit uses a Formazine Standard for measurement of Jackson Turbidity Units by light transmittance through the water sample from a photocell. Wellmixed 25.0-ml water samples were used and compared against blanks of deionized-distilled water. Glassware was washed with-additional river water sample before use.

Flow

Flow records for the stations that had gauges were obtained from the US Geological Survey.

At all stations during times of low flow and at the Farmington Station at all times, the method described in Welch (1948) was used to estimate the streamflow. This method uses the width of the channel (w), the average depth of the water (d), the velocity of the water over a predetermined distance ( $1 /$ time), and a coefficient of friction ( $f$ ), to estimate the flow ( $Q$ ) by using the formula $Q=1 \mathrm{wdf} / \mathrm{t}$. The flow, $Q$, is measured in cfs or $\mathrm{m}^{3} / \mathrm{s}$ depending on the units of measurement used. 
Inorganic Carbon

In soft waters of low alkalinity, ammonia can appreciably affect the alkalinity of the water (Stumm and Morgan 1970). This alkalinity due to ammonia must be determined and subtracted from the total alkalinity to obtain the carbonate (or bicarbonate) alkalinity. The formula used to determine the bicarbonate (all samples had a $\mathrm{pH}<8.3$ ) was:

Bicarbonate alkalinity as $\mathrm{mg} / \mathrm{l} \mathrm{CaCO}_{3}=(0.02(\mathrm{Alk} \cdot \mathrm{T})-\mathrm{mg} / \mathrm{I}$ $\left.\mathrm{NH}_{4}^{+}-\mathrm{N} / 14\right) 50$.

The bicarbonate alkalinity is then used with Saunders, et al. (1962) table to calculate the total inorganic carbon. This procedure allows for the impact of $\mathrm{pH}$ and temperature on the bicarbonate availability.

Trace elements

Trace elements (iron, copper, cobalt, molybdenum, cadmium, lead, nickel, zinc, arsenic, chromiun) and a major ion, potassium, were analyzed by atomic absorption at the Pacific Northwest National Environmental Research Center of the US Environmental Protection Agency in Corvallis, Oregon, through the courtesy of Dr. Daniel Krawcyzk. From each sample set one liter of river water was preserved with 25.0 $\mathrm{ml}$ conc. $\mathrm{HNO}_{3}$ (analytical reagent) in a collapsible soft plastic container. The water samples were not filtered before analysis. 
Net Plankton and biological diversity

From the main current of the river 189 liters (50 gallons) of water were poured through a nylon (\#20 bolting cloth) plankton net attached to a $125-\mathrm{ml}$ container. This cloth had apperatures of 76 microns and has 173 meshes to the inch. The 125-ml volume of water and planktonic material was transferred into a plastic bag (NASCO 18 oz Whirl-Pak) for storage. In the laboratory a measured and well-mixed amount of the water was suction filtered through a $47 \mathrm{~mm}$ Millipore filter $(0.45 \mu \mathrm{m}$ pore size). The amount of the planktonic sample filtered ranged from $1.6 \mathrm{ml}$ during very turbid flood conditions to $100 \mathrm{ml}$.

The filters were trimmed to size, placed on microscope slides and covered with low florescence, non-drying Cargille Transparency Medium (index of refraction $=1.5 .15$ ). This medium makes the cellulose acetate Millipore filters transparent. When the filters were dry, an additional drop of transparency medium and a cover slip were added.

In the late spring and summer of 1973 fresh planktonic material was examined for organisms present in the samples. This was done because the immersion oil (medium) and the drying of the material on the prepared slides tend to distort certain algae.

The Membrane Filter Concentration Technique of section 601 A of Standard Methods (APHA 1971) was used to count the organisms on the prepared slides for diversity studies. 
Additionally, the membrane filter technique requires the identification of the organisms in the net plankton samples. From this information and from the examination of the fresh planktonic material a check-list of net planktonic organisms, both phyto- and zoo- plankton was compiled (Appendix B). 


\section{CHAPTER V \\ OBSERVATIONS AND RESULTS OF THE STUDY}

\section{PHYSICAL PARAMETERS}

\section{$\underline{\text { Flow }}$}

The volume of flow (discharge) of the Tualatin River was measured at Farmington Station from July 1972 to September 1973 (Table III). In addition in July and August of each year the discharge of all stations was measured.

At Farmington Station the measured discharges ranged from $370 \mathrm{~m}^{3} / \mathrm{s}(13,000 \mathrm{cfs})$ in January to $0.6 \mathrm{~m}^{3} / \mathrm{s}$ (22 cfs) on 4 August 1973. However, the maximum flow was probably on 22 December 1972 (USGS 1973). By extrapolation it is possible to estimate the flow for that day at about $570 \mathrm{~m}^{3} / \mathrm{s}(20,000$ cfs) which is 1000 times the low flow.

Table III gives the field measurements for the flow of the river and the US Geoiogical Survey records for the study period. Gauges for some of the tributaries and for the main river at Gaston and Farmington were not reactivated by the US Geological Survey until May 1973. At the time of the low flow in July and August 1973 there was some doubt concerning the validity of the US Geological Survey data from Farmington Station. The measured volume of water and the observed velocity of the water did not correlate with their recorded data. 


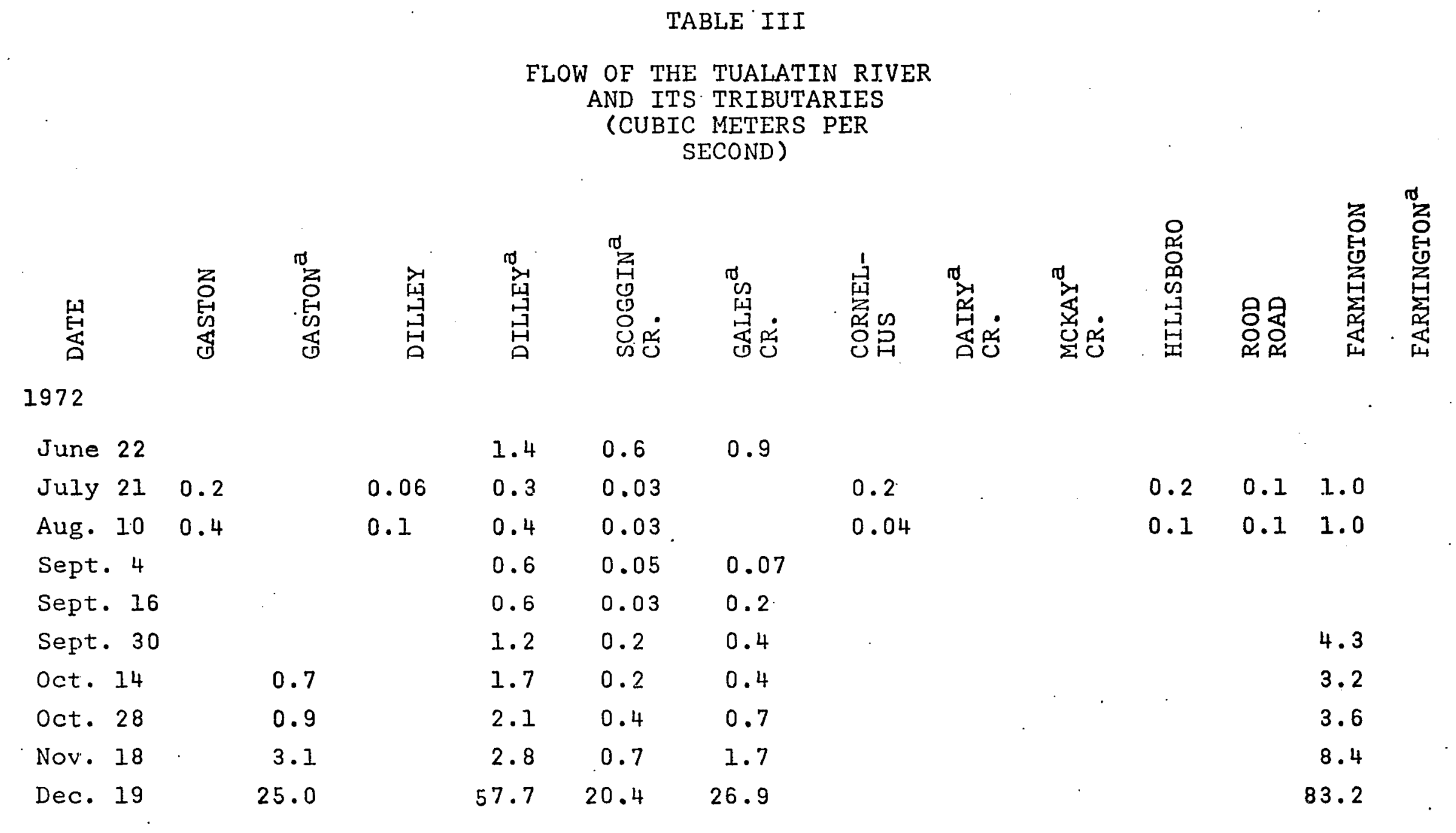




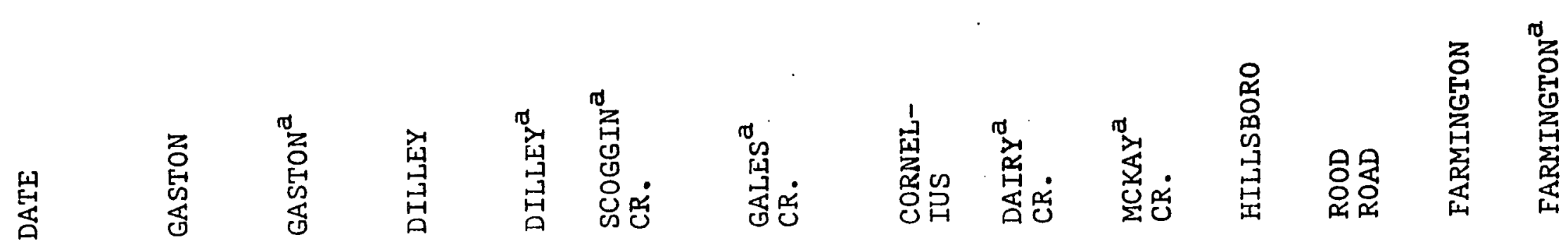
1973

\begin{tabular}{|c|c|c|c|c|c|c|c|c|c|c|c|c|}
\hline Jan. 13 & & 32.8 & 78.7 & 24.7 & 42.9 & & & & & & 366.4 & \\
\hline Feb. 3 & & 4.5 & 10.8 & 4.1 & 5.3 & & & & & & 31.3 & \\
\hline Mar. 3 & & 6.8 & 19.9 & 5.9 & 9.2 & & & & & & 76.9 & \\
\hline Mar. 23 & & 5.0 & 10.2 & 4.1 & 5.2 & & & & & & --- & \\
\hline Apr. 16 & & 2.7 & 4.7 & 2.0 & 2.8 & & & & & & 20.6 & \\
\hline May 5 & & 1.9 & 3.2 & 1.2 & 2.0 & & 2.6 & 0.7 & & & 15.3 & 11.0 \\
\hline May 25 & & 1.5 & 2.8 & 1.0 & 1.5 & & 2.3 & 0.8 & & & 7.2 & 10.6 \\
\hline June 16 & & 0.8 & 1.3 & 0.6 & 0.9 & & 0.9 & 0.2 & & & 3.7 & 3.2 \\
\hline July 7 & $\therefore$ & 0.4 & 0.7 & 0.3 & 0.5 & & 0.3 & 0.07 & & & 1.7 & 1.8 \\
\hline July 21 & & 0.5 & 0.4 & 0.2 & 0.3 & 0.2 & 0.3 & 0.02 & 0.0 & 0.0 & 0.7 & 0.4 \\
\hline Aug. 4 & & 0.3 & 0.2 & 0.04 & 0.1 & 0.06 & 0.2 & 0.01 & 0.0 & 0.0 & 0.6 & 0.3 \\
\hline Aug. 18 & 0.6 & 0.4 & 0.5 & 0.08 & 0.2 & 0.5 & 0.2 & 0.01 & 0.3 & 0.1 & 1.6 & 0.5 \\
\hline Sept. 8 & & 0.4 & 0.6 & 0.04 & 0.3 & & 0.3 & 0.02 & & & 2.4 & 1.7 \\
\hline
\end{tabular}

a. USGS; 1973

Note: $\mathrm{m}^{3} / \mathrm{s}=$ cfs $\times 0.028$ 
There was some flow throughout the summer of 1972 . However, in 1973, one of the driest years reconded, flow from about RM 44.8 to RM 38.1 (the mouth of Rock Creek), ceased during part of July and August. The July 21 and the August 4 measurements showed no preceptable flow at either Hillsboro or Rood Road Station. The flow of the river at Farmington Station downstream came from Rock Creek and was the result of effluents from numerous sewage treatment plants in the drainage basin of that tributary.

As important as the fact that there was no flow in the river from Dairy Creek to Rock Creek during the summer of 1973, was the fact that from Gaston to Dainy Creek the flow of the river from May to September was almost entirely controlled by the amount of irrigation water withdrawn along that section of the river and its tributaries. It was not unusual for the river to show as much as 0.3 to $0.5 \mathrm{~m}$ (I to $1.5 \mathrm{ft}$ ) difference (up or down) in water level between morning and afternoon sampling periods. The flow of water along the whole mainstem was resumed when the need for irrigation water was reduced by the harvesting of crops; not because of any rainfall or run-off. Because of this erratic flow pattern due to man's consumptive water use, it is difficult to correlate the flow of the river with any other parameter.

Eigure 15 depicts. the relationship of each tributary to the mainstem Tualatin and the contribution each tributary makes to the average annual flow of the river. 


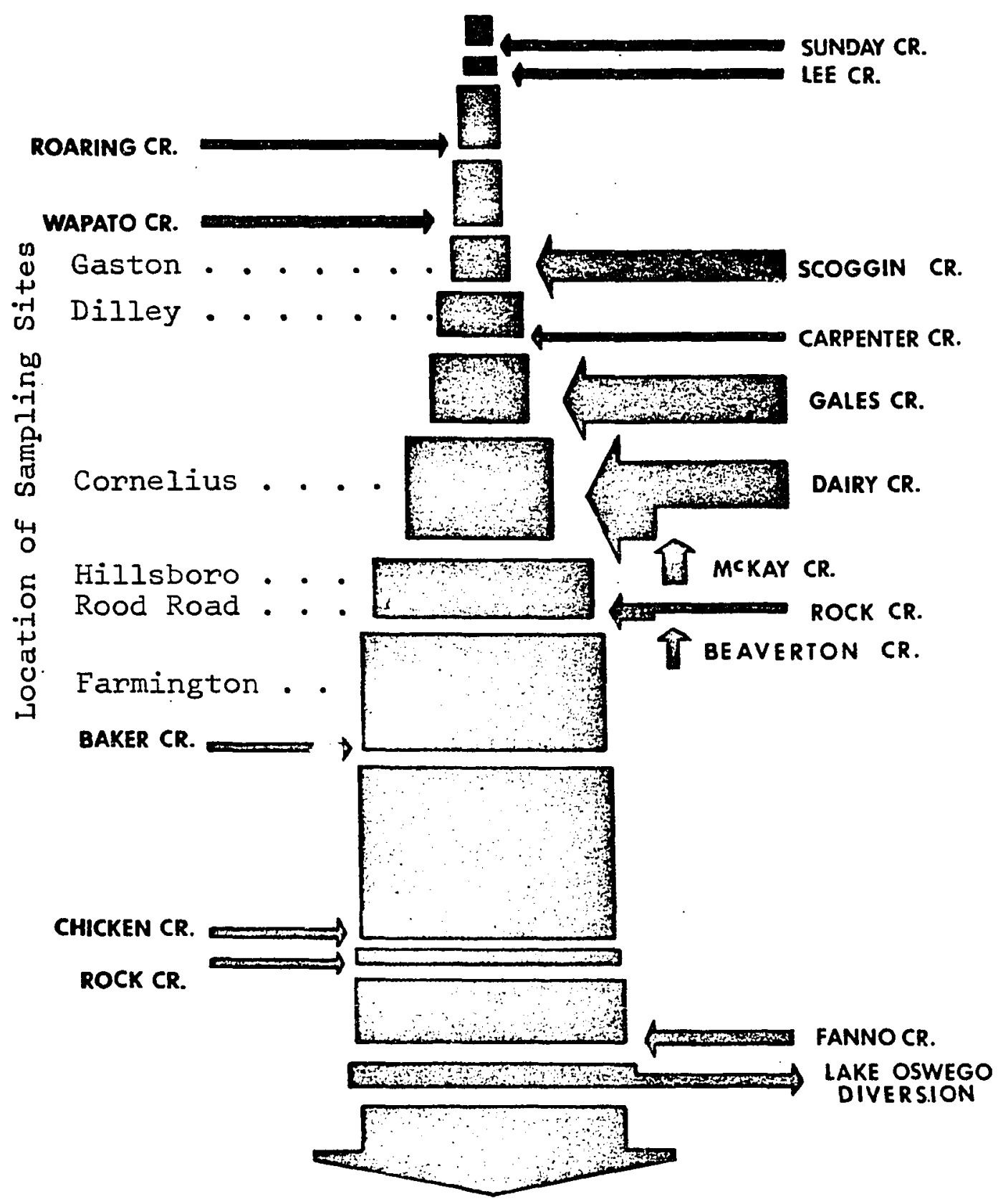

Figure 15. Average annual flow, Tualatin River and selected tributaries in approximate volume relationship of each (STR 1969). Sampling sites for this study are also shown. 
The maximum velocity of the water measured at Farmington Station was $2.1 \mathrm{~m} / \mathrm{s}(6.8 \mathrm{fps})$; the minimum velocity was $0.08 \mathrm{~m} / \mathrm{s}(0.25 \mathrm{fps})(T a b l e \mathrm{IV}$, Figure 16). The slowest measured flow for $1972,0.10 \mathrm{~m} / \mathrm{s}(0.4 \mathrm{fps})$, was also on July 21 .

The velocity of the water is an important factor in the type of sediment, stream bed material, and aquatic life in a river. In fact the velocity of the streamflow is one of the most important abiotic factors in determining the type of aquatic life in a river (Fraser 1972; Hynes 1970).

Flow at the continuing rate of more than $2 \mathrm{~m} / \mathrm{s}$ will cause scoring of the river channel; at the rate of 0.02 to $0.2 \mathrm{~m} / \mathrm{s}$ the stream bed will consist of mineral organic muds and large quantities of organic detritus (Ruttner 1963). Both of these conditions were noted for the Tualatin River at different seasons.

\section{Temperature}

The water in the Tuzlatin River was warmest during July and early August of 1973 and in August of 197.2. Even though the summer of 1973 was one of the driest in 97 years, the temperatures of the river were not as high as those of the previous year. Figure 17 shows the water temperatures at the six river stations, Figure 18 shows this parameter for Rock Creek. The air temperatures for all sampling times are given in Appendix D.

At the same time that the river temperatures were high, 
TABLE IV

VELOCITY OF THE VATER AT FARMINGTON BRIDGE

JULY 1972 TO SEPTEMBER 1973

DATE

1972

July 21

August 10

September 30

October 14

October 28

November 18

December 19

1973

January 13

February 3

March 3

April 14

May 5

May 25

June 16

July 7

July 21

August 4

August 18

September 8 $\mathrm{m} / \mathrm{s} \quad \mathrm{ft} / \mathrm{s}$

$0.1 \quad 0.4$

$0.1 \quad 0.4$

$0.4 \quad 1.2$

$0.3 \quad 1.0$

$0.3 \quad 0.9$

$0.4 \quad 1.4$

$0.6 \quad 2.1$

$\begin{array}{ll}2.1 & 6.8 \\ 0.6 & 2.1 \\ 0.6 & 1.9 \\ 0.6 & 1.8 \\ 0.5 & 1.7 \\ 0.6 & 2.1 \\ 0.3 & 1.0 \\ 0.2 & 0.7 \\ 0.08 & 0.2 \\ 0.1 & 0.3 \\ 0.2 & 0.6 \\ 0.3 & 0.8\end{array}$

$2.1 \quad 6.8$

$0.6 \quad 2.1$

$0.6 \quad 1.9$

$0.6 \quad 1.8$

$0.5 \quad 1.7$

$0.6 \quad 2.1$

$0.3 \quad 1.0$

$0.2 \quad 0.7$

$0.08 \quad 0.2$

$0.1 \quad 0.3$

$0.3 \quad 0.8$ 


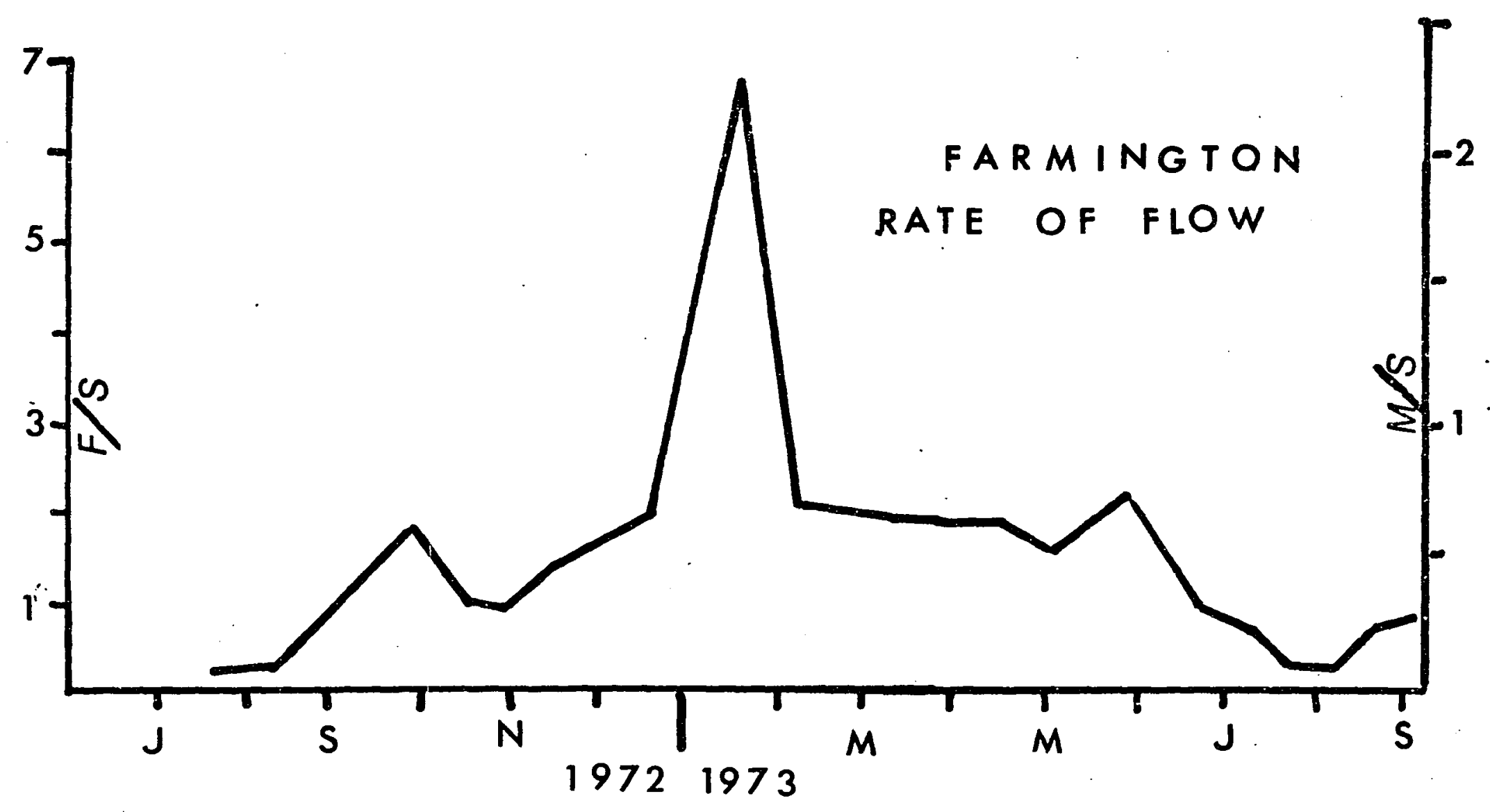

Figure 16. The rate of flow in $\mathrm{m} / \mathrm{s}$ or fps at Farmington Bridge, 1972-1973. The slow rates in late July are due to agricultural irrigation as well as lack of run-off from precipitation. 
the crayfish and mussels remaining in the non-flowing pools at Rood Road Station were showing signs of distress.

From 4 to 16 December 1972 there was an extreme cold spell with snow on the ground. Air temperatures recorded officially at Forest Grove were $-20 \mathrm{C}(-4 \mathrm{~F})$ (NOAA 1972). At this time the river froze over completely for the second time in 50 years with a layer of ice $10 \mathrm{~cm}$ ( $4 \mathrm{in}$ ) thick. The prolonged cold spell brought about a buildup of ice along the bottom of the river. According to Hynes (1970), anchor ice can only form on very cold still nights and when there is no ice cover on the water. This was not the weather pattern, nor the condition of the river, yet ice formed on the river bottom. This unusual freezing may have had serious impact on the aquatic organisms of the river. In the backwaters of the river after the flood following the freeze there were dead fish (warm-water species). These may have been from flooded farm ponds or from the river itself. The cold spell was brought to an end by a warm rain (14C air temperature) which rapidly melted the snow cover on the whole watershed causing the river to flood. As the ice broke up, it was flushed down stream by a warmer water mass from the rain run-off. Thus the temperature of the water at Gaston ( 6 to $7 C$ ) was 5 to $6 C$ warmer than downstream at Farmington (IC) where ice packs were still in the river. Usually the water temperatures were higher downstream. 


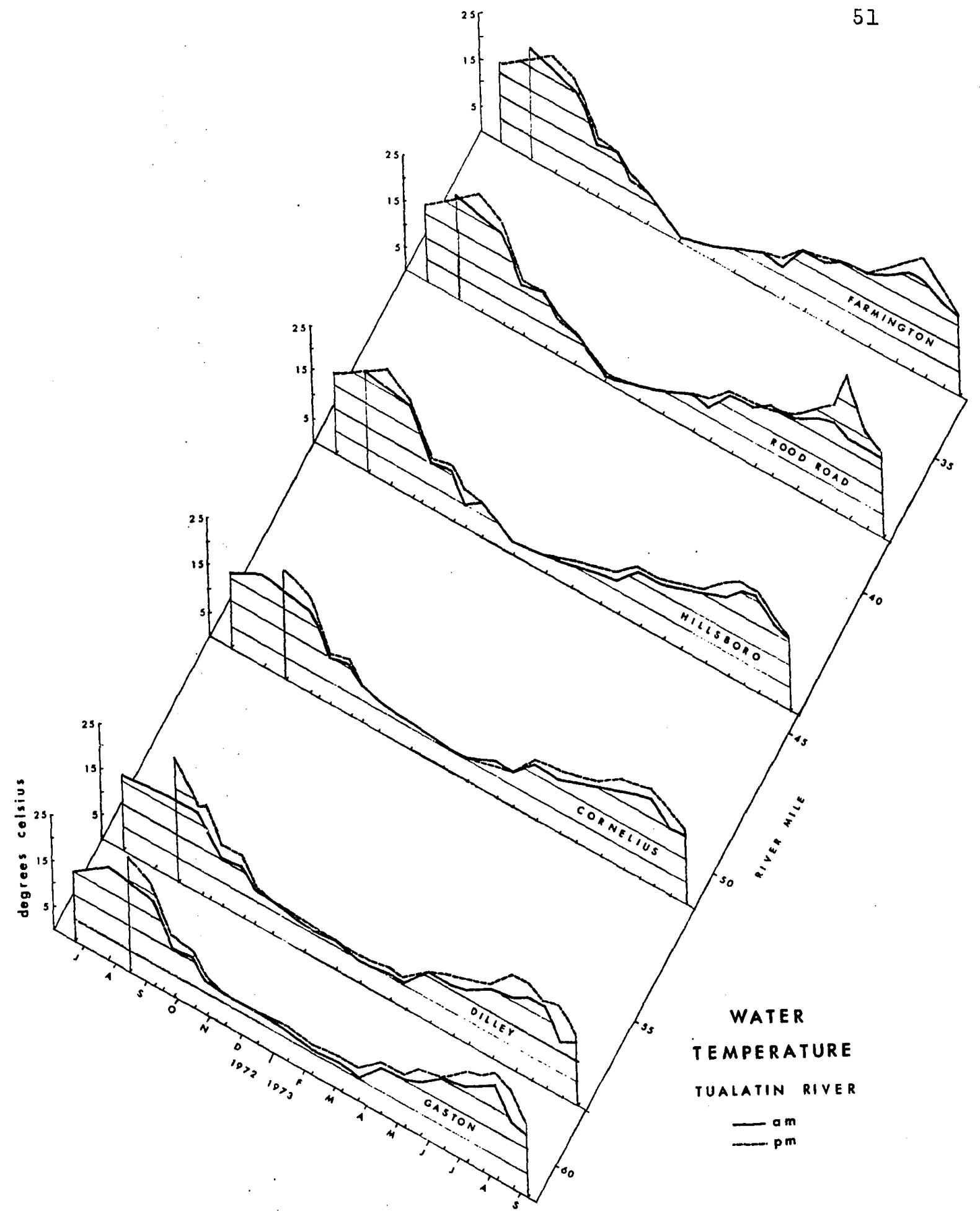

Figure 17. Temperature of the water in degrees Celsius in the Tualatin River, 1972-1973. There were greater daily variations in the water cemperatures in the sumner, especially at times of minimal or zero flow. 

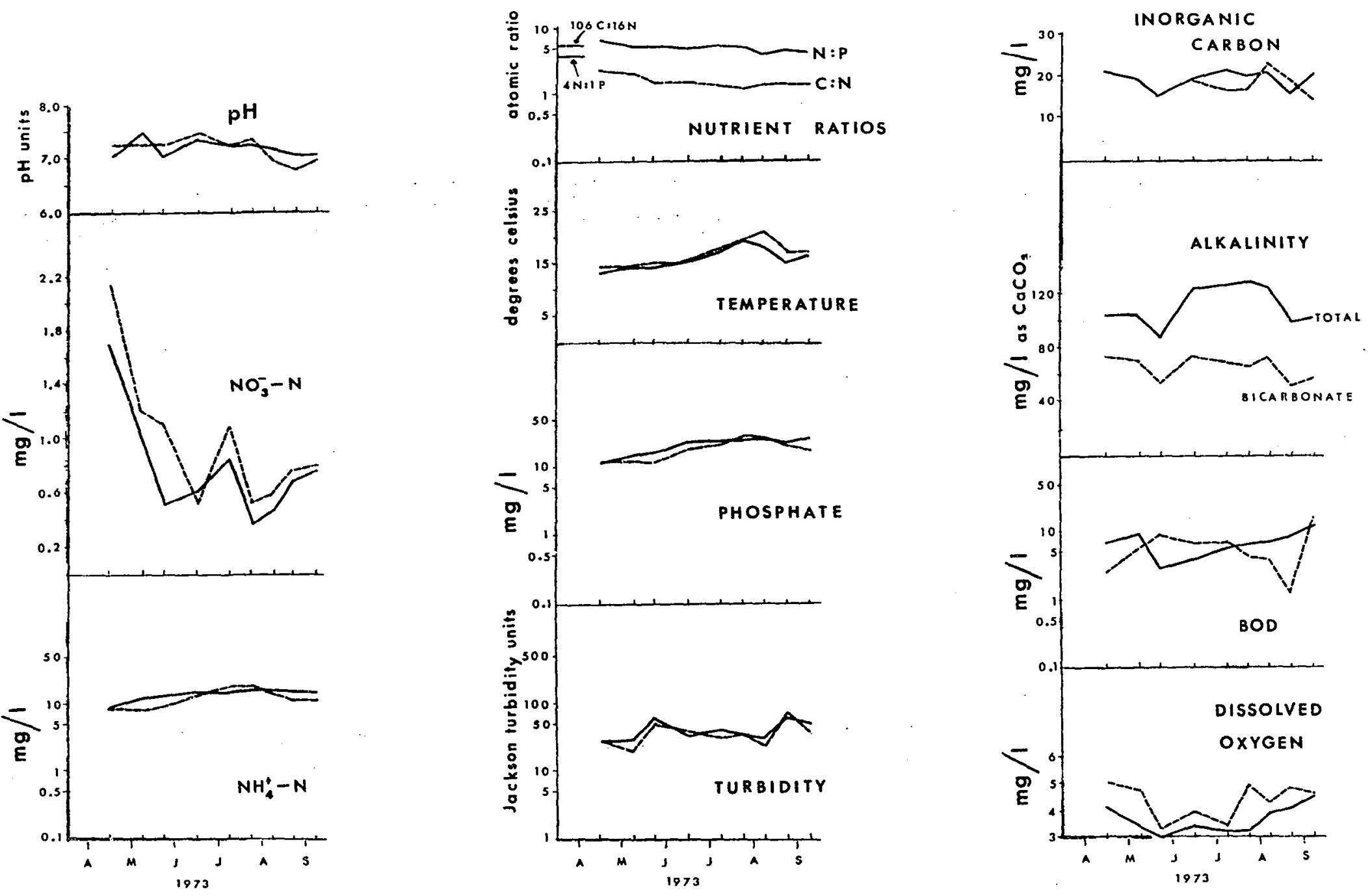

Figure 18. Chemical parameters in Rock Creek, a tributary of the Tualatin River between Rood Road and Farmington Stations, 1973. Samples were taken upstream from the Hillsboro-Eastside sewage treatment plant. These graphs have the same scale as similar graphs for each parameter on the mainstem river. 
Turbidity

Turbidity is the expression of the optical property which causes light to be scattered and absorbed rather than transmitted in a straight line through a water sample (FWPCA 1968). Turbidity in water is caused by the presence of suspended matter, such as clay, silt, finely divided organic and inorganic matter, and plankton (APHA 1971). Most streams flowing near base level. carry considerable loads of silt and fine particles. Many of the large rivers in the United States have turbidity values which exceed 1000 JTU (Reid 1961). In some western states streams have turbidities of less than 25 JTU's most of the year (FWPCA 1968). The range of turbidities in the Tualatin River was zero to 225 JTU (Figure 19).

Turbidity readings were started with the December 1972 flood and except during the floods, the turbidities were higher downstream. The water in the morning was usually more turbid than in the afternoon. However, at Farmington Station in the late spring and throughout the summer when plankton was present, there was more turbidity in the afternoon.

During the floods the highest turbidity occurred either at Cornelius or Hillsboro Stations (Figure 19), where the initial impact of Gales Creek and Dairy Creek greatly influenced the mainstem river. Figure 1 (page 4) indicates that about $85 \%$ of the flood flow enters the river above Hillsboro 


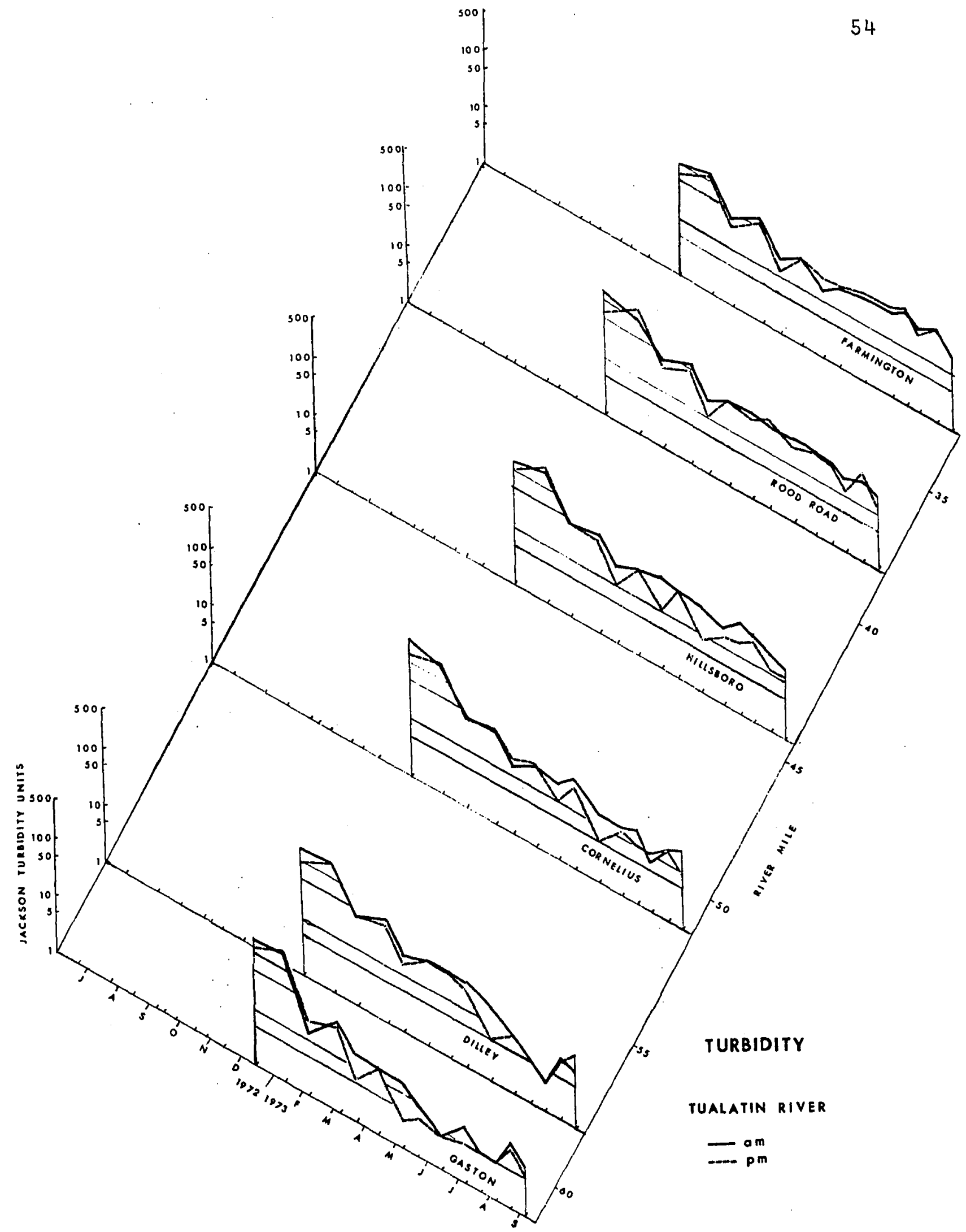

Figure 19. Turbidity in Jackson Turbidity Units (Formazine Standard) in the Tualatin River, 1973. Turbidity was higher at flood time. Summer turbidity was due to organic matter in the water. 
Station. The two most upstrean stations, Gaston and Dilley, had higher turbidities during the floods than the two most downstream stations, Rood Road and Farmington. The flooding of the water over the floodplain reduced the velocj.ty of the water and hence its capacity to carry as much sediment, reducing the turbidity.

The four upstream stations had higher turbidity in the winter. Gaston, Cornelius, and Hillsboro Stations had their lowest turbidity in June; however, Rood Road and Farmington, the downstream stations, had their lowest turbidity in March. By June the production of algae increased the turbidity at the downstream stations. Dilley Station had its lowest turbidity in August 1973 when the pool of water behind a temporary sandbag dam reduced the velocity of water and the suspended materials settled out.

From the spring to fall of 1973 the range of turbidity at Rock Creek was from 20 to 65 JTU (Figure 18). Some of this turbidity was caused by run-off, but some was the result of suspended solids in the effluents from upstream sewage treatment plants.

A 6C (IOF) drop in the minimum air temperatures on 17 August 1973, the day before the August 18 sampling, may have affected the turbidity of the river. The extensive algal blooms had diea, thus the turbidity of the water may have been the result of suspended algal detritus. Aquatic biologists who regularly sample the streams in Oregon have 
observed that algal blooms deciine significantly with a sudden drop in the minimum air temperatures in August (McHugh et al. pers. comm.).

In the winter the turbidity of the river was the result of higher flow velocity and its resultant sediment transport. In the summer fine suspended sediments and aquatic organisms produced turbidity. This was evident from the slides prepared for the study of the net plankton which also contained the silts and organic matter caught in the plankton net. The relative amounts of inorganic and organic matter and aquatic organisms in the river were easily noted (but not quantified).

\section{CHEMICAL PARAMETERS}

\section{Dissolved oxygen}

The middle course of the Tualatin River, with its smooth, silt, clay, or sandy bottom and lack of turbulence, shows the characteristics of a slow, sluggish stream (Hynes 1970). Dissolved oxygen concentrations were lower downstream and in the summers except where there were algal blooms (Figure 20). Gaston Station was the most stable relative to precent saturation (Appendix D).

From February to August of 1973 dissolved oxygen values were higher in the afternoon than before dawn due to photosynthetic activity within the river. During the fall and 


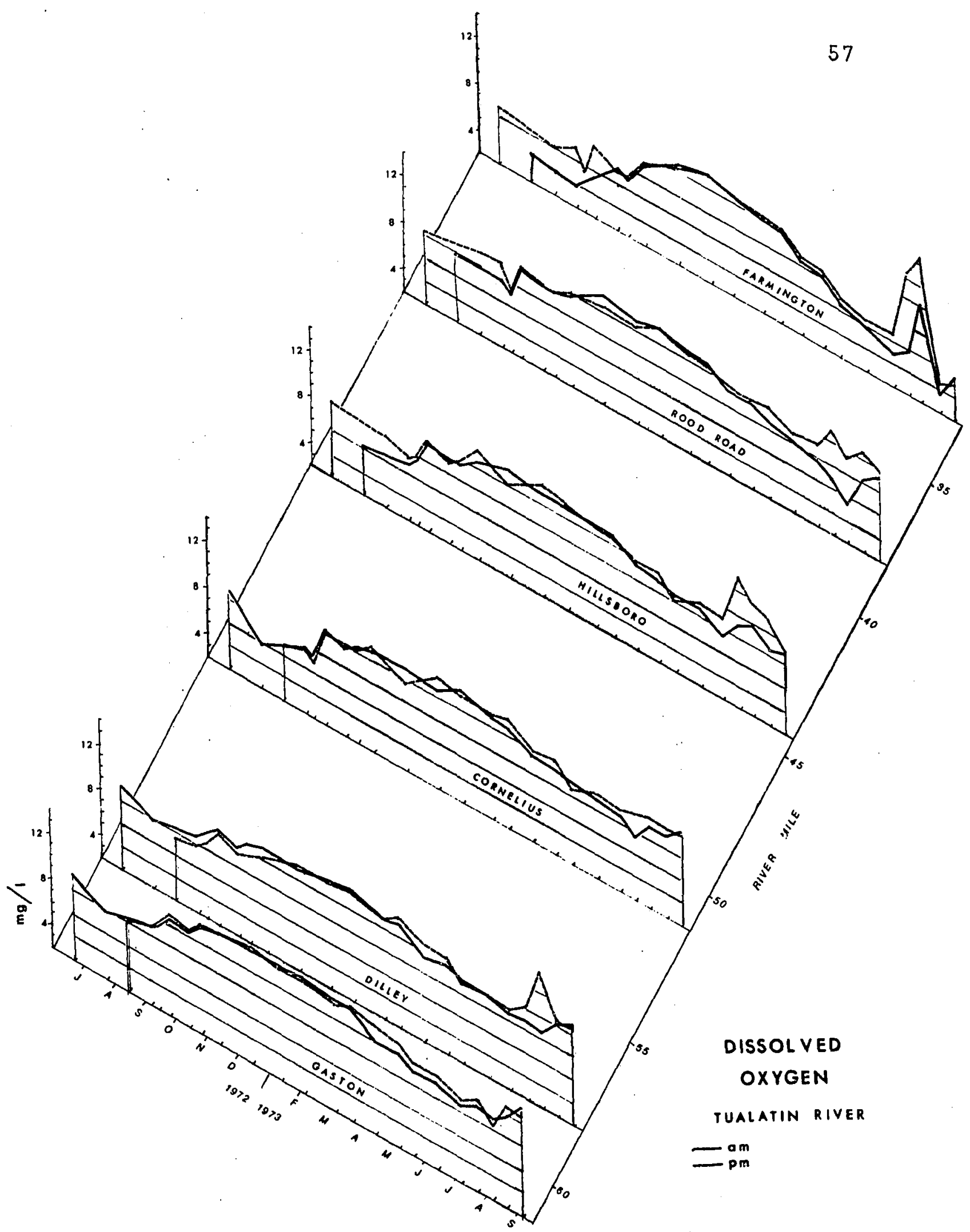

Figure 20. Dissolved oxygen in $\mathrm{mg} / \mathrm{l}$ in the Tualatin River, 1972-1973. Upstream stations had more Do the year around. Algal blooms created summer highs and greater daily variations at downstream stations. 
winter of 1972 there were no predictable differences between morning and afternoon values. Most of the year there was little daily variation in the concentrations of the dissolved oxygen, but in the summer the variations were greater, especially at stations where the flow was greatly reduced. The 1973 high oxygen value at Dilley Station was caused by the bloom of Melosira spp. in the pool behind a sandbag dam. When the normal flow of water was resumed, the dissolved oxygen concentrations were once again more stable.

Regulations adopted by the State of Oregon Department of Environmental Quality (DEQ) in 1967 set the minimum standard for dissolved oxygen in the Tualatin River below Gaston as $6.0 \mathrm{mg} / \mathrm{I}$ (DEQ 1974a). Connelius Station was below this standard in July 1972; Rood Road Station on August 4, 1973 as well as JuIy 1972. Farmington Station was above minimum standard only from late September 1972 to early June 1973, except during the massive algal bloom of 4 August 1973. Rock Creek which must meet the mainstem Tualatin River standards according to the DEQ regulations never had acceptable dissolved oxygen corcentrations (Figure 18). From April to September 1973 Rock Creek had dissolved oxygen values between 3.0 and $5.0 \mathrm{mg} / \mathrm{I}$ which influenced Farmington Station. Because of the combined effect of the Rock Creek effluent, the elevated summer temperature, and reduced or zero flows in the mainstem Tualatin above Rock Creek, Farmington Station shows dissolved oxygen concentrations that indicate stress to 
water quality in the early morning hours of summer. By late August when the algal blooms had died, the afternoon dissolved oxygen concentrations at Farmington Station were also sub-standard.

The loading of organic matter which is oxidized by microbes in the river is the major calse of oxygen depletion. This organic matter may be run-off from the watershed, forest debris and leaves, or human domestic wastes.

The dissolved oxygen values obtained during the summer indicate that the river can accommodate relatively well to organic matter present naturally, but not to the added human domestic wastes. Low flow in summer does not dilute the highly concentrated effluents from sewage treatment plants on Rock Creek. Respiration and oxidation of these effluents of organic matter demands large amounts of dissolved oxygen. The algal blooms in the river may be unsightly, but the oxygen they produce is instrumental in keeping the aquatic ecosystem from becoming anoxic. In effect the river is acting as an oxidation lagoon for sewage. Biochemical oxygen demand

Biochemical oxygen demand (BOD) is the amount of oxygen needed for the respiratory activities of microorganisms which utilize organic matter for growth (Gaudy 1972). Thus, $\mathrm{BOD}$ is a measure of the microbial degregation of onganic matter, although chemical oxidation of resuspended sediments 
can also decrease dissolved oxygen and thereby contribute to the BOD.

Figure 21 shows the BOD of each of the sampling stations for the study time. Figure 18 shows the BOD in Rock Creek. The BOD was high $(3.0 \mathrm{mg} / \mathrm{l})$ at Gaston only during the winter flooding when previously deposited organic matter and sediments were scoured from the streambed. At this station the highest $B O D$ value that could be attributed to organic decay was $2.3 \mathrm{mg} / 1$ on 8 September 1973. The river water at Gaston is low in organic matter and thus in BOD.

The effluents from the sewage treatment plant at Gaston enter the river above Dilley the year around. Only in the winter are effluents from the fiberboard processing plant on Scoggin Creek released into that creek. (The Stimson Forest Fiber Products Mill has a BOD discharge permit from the DEQ (1974b) for 600 pounds BOD/day from November 1 to April 30; they are not allowed to discharge from May 1 to October 31.) Hence, the BOD at Dilley Station is greater in the winter, especially from October to February.

At Cornelius the BOD ranged between 1.0 and about 3.0 $\mathrm{mg} / 1$. There are a number of dairies in this area which must dispose of their animal wastes. Some of the dairies use concrete, holding tanks where the solids are liquidified by bacteria and then irrigated on land by sprinklers. 0ther dairies spread the manure on the land as a solid, which can then enter the river as run-off from rainfall on after 


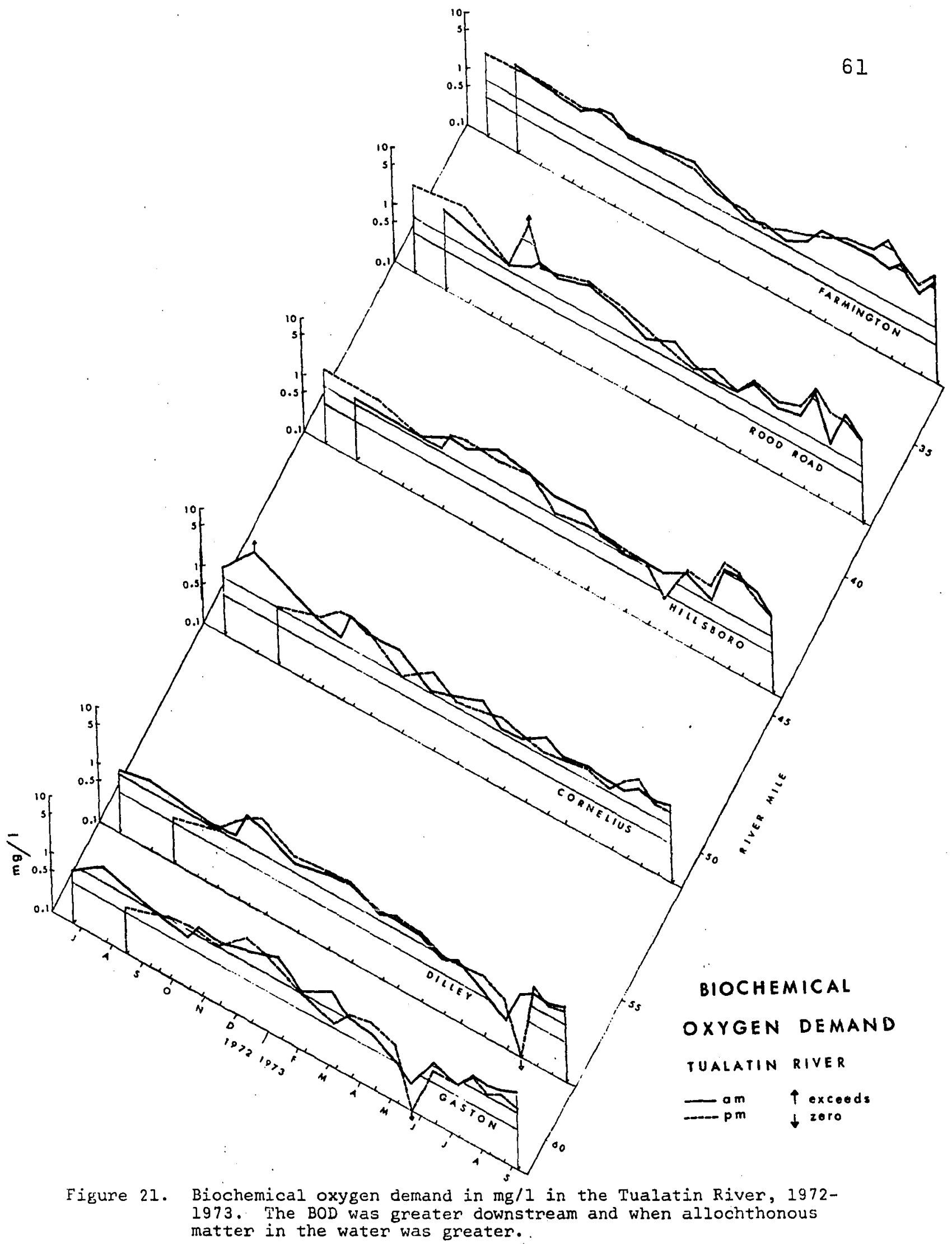


prolonged irrigation.

At Hillsbora the higher BOD values can be attributed to the transport of organic material from upstream. Both Forest Grove and Cornelius have secondary sewage treatment plants. The impact of periods of ineffective operation of the plant at Forest Grove can presentiy be reduced by their oxidation lagoons, but there is often a high population of algae in the discharges from these lagoons. The overloaded plant at Cornelius is to be discontinued, but it still discharged effluents during this study.

During the zero flow period in 1973, BOD values were high at Hillsboro Station. There was a bloom of Microcystis sp. in the river at that time which kept the river from becoming anoxic.

Rood Road Station, below the secondary treatment plant of the city of Hillsboro, shows the effects of that municipality's organic wastes as well as irrigation drawdown. In summer (June 1 to November 1) effluents from the food processing plants are given primary treatment, chlorinated, and then sprayed on the Industrial Sewer Farm along with the city's domestic wastes that have received secondary treatment. At times these fields of the Sewer Farm become saturated and the seepage or run-off affects the river downstream. There is also a byrpass ditch for part of the Sewer Farm which often runs water in the summer and contributes organic material for the BOD of the river. 
In the summer the BOD values are high at Farmington Station because the flow of water there is primarily sewage effluents from Rock Creek. The highest BOD reading in the main river was $12.5 \mathrm{mg} / \mathrm{I}$; the highest in Rock Creek (above the second Hillsboro sewage treatment plant) was $12.4 \mathrm{mg} / \mathrm{I}$. The DEQ (1969) minimum standard for effluent discharges into the river downstream from Gaston is $10 \mathrm{mg} / 1$ BOD. Thus, the river had a BOD greater than was allowed in the effluents from sewage treatment plants. Again, if it had not been for the algal blooms which produced oxygen in the river in the summer, the $B O D$ could have reduced the river to conditions of anoxia.

\section{Alkalinity}

In the analyses for alkalinity two values were determined; total alkalinity and bicarbonate alkalinity. TataI alkalinity is equivalent to the amount of a mineral acid necessary to overcome the buffering capacity of the water sample. Normally the principal buffering species in natural waters are $\mathrm{CO}_{3}, \mathrm{HCO}_{3}^{-}, \mathrm{OH}_{\overline{3}}$ and $\mathrm{H}^{+}$. Because the $\mathrm{pH}$ of the river was never found to be above 8.0 , alkalinity in the Tualatin was a measure of the bicarbonate ion, except in special cases when other ions exerted an influence on the alkalinity (Stumm and Morgan 1970). In the Tualatin River one such ion of significance was the ammorium ion. Therefore, the bicarbonate alkalinity was obtained by subtracting 
the influence of the ammonium ion from the total alkalinity (see methods). There was almost no difference in the upstream stations, but Farmington Station and Rock Creek were seriously affected by the ammonium ion, especially in the summers (Figure 22, Figure 18). This influence was noted at al. stations for unbiased comparisons (Appendix D).

The lowest alkalinities were found during the December 1972 flood; the highest during the extremely dry summer of 1973, specifically on August 4. For the three months, May, June, and July only $4.45 \mathrm{~cm}$ ( $1.75 \mathrm{in}$ ) of rain fell (NOAA 1973).

The low alkalinities during the December flood were from snow-melt. The alkalinity of the snow was zero; its $\mathrm{pH} 4.5$. A vast amount of snow-melt water entered the river and decreased the alkalinity of the river.

Alkalinities usually increased downstream on any one day, and increased from winter to summer. Farmington Station bicarbonate alkalinities declined in the summer. From early Jily to September 1973, the bicarbonate alkalinity values at Farmington Station were lower than those upstream at Rood Road Station. However, total alkalinities were higher at Farmington Station that at Rood Road because of high ammonium-nitrogen loadings from Rock Creek and its sewage effluents. Nitrification could have caused the lower bicarbonate alkalinities at Farmington Station, because nitrifying bacteria use inorganic bicarbonate ions during 


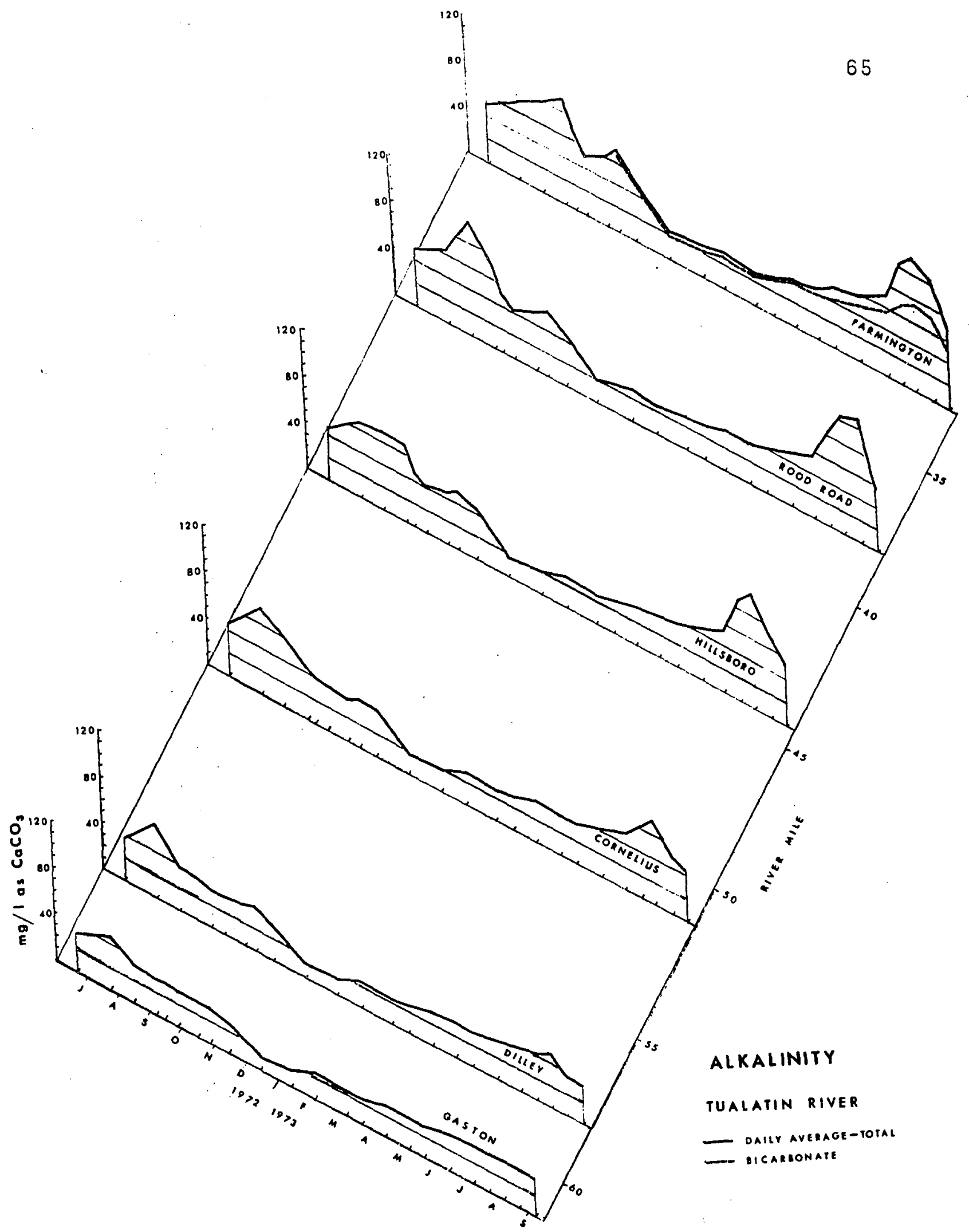

Figure 22. Total alkalinity in $\mathrm{mg} / \mathrm{I}$ as $\mathrm{CaCO}_{3}$ in the lualatin River, 1972-1973, and bicarbonate alkalinity in $\mathrm{mg}^{/ 1} 1$ as $\mathrm{CaCO}_{3}$ at Farmington Station, 1973. Alkalinities were higher downstream in the summer. Bicarbonate alkalinity at Farmington was significantly lower than the total alkalinity, at other stations there was little difference. 
nitrification. Goering (1972) states the decrease of inorganic carbon species can be the result of both nitrification and photosynthesis.

$\underline{\mathrm{pH}}$

The $\mathrm{pH}$ of the river ranged from 6.2 to 8.0 units during the study period. The highest $\mathrm{pH}$ values were found at Dilley Station. In August 1973, a sand-bag dam placed across the river by the US Geological Survey for their flow gauge caused the water to pool and resulted in an extensive bloom of Melosira varians which increased the $\mathrm{pH}$. There is no apparent explaination for the $8.0 \mathrm{pH}$ value in October 1972 .

Gaston showed the greatest variability of $\mathrm{pH}$; Farmington the most stability (Figure 23). The increasing stability of $\mathrm{pH}$ downstream was related to the increase in alkalinity and hence the buffering capacity of the water.

Two events which led to $\mathrm{pH}$ changes along the whole watercourse were the December 1972 flood, and the extreme low flows of late July and early August of 1972 and 1973. The flood was caused by the run-off from a snow pack over the whole watershed. The $\mathrm{pH}$ of the snow was 4.5 , so that the mixing of the river water and the snow melt depressed the $\mathrm{pH}$ for the whole river.

The higher $\mathrm{pH}$ values found in the summer when the water pooled or didn't flow were due to photosynthesis. 


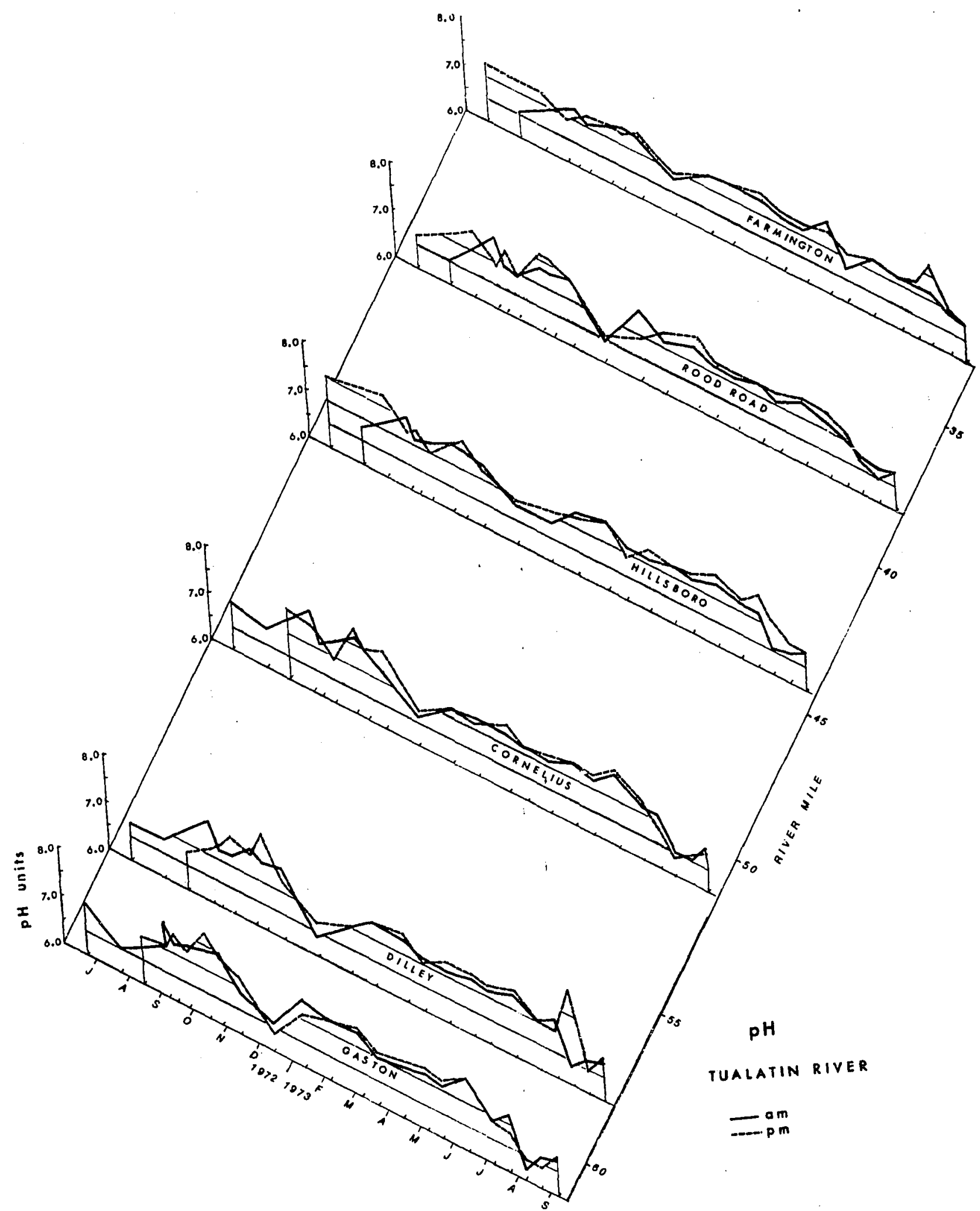

Figure 23. $\mathrm{pH}$ in standard units in the Tualatin River, 1972-1973. Snowmelt in winter lowered the $\mathrm{pH}$; and algal blooms in the summer raised the $\mathrm{pH}$ of the water. 
From February to late May $\mathrm{pH}$ was relatively constant. During this time afternoon $\mathrm{pH}$ readings were higher than morning readings by 0.1 to 0.2 units. This afternoon elevation of $\mathrm{pH}$ follows the afternoon increase in dissolved oxygen for the same period, and is related to photosynthesis.

Trace elements

For this study trace elements are defined as those elements with concentrations in the water of less than $1 \mathrm{mg} / \mathrm{I}$. Potassium, which is not a trace element but a major ion, is also included.

Unfiltered water samples from selected stations in the Tualatin River watershed were measured for total concentrations of each element by atomic absorption methods.

There is no other available data on trace metals in the Tualatin River or in the soils of the valley.

If the concentration of an element decreases with increased flow, it implies a constant source which is diluted as the flow increases. If the concentration of the element is independent of the flow then it is a product of a constant leaching process (Andlemann 1973). Andlemann (1973) states that there is a great variation in the concentrations of a trace element in a river.

Arsenic. Arsenic was usually below the detection level ( $5 \mu \mathrm{g} / 1$ ), but was found in October 1972 at the time of the fall rains and run-off (Table V). Arsenic was also detected 
in the December 1972 flood below the major farning areas of Dilley, Cornelius, and Hillsboro Stations.

Rock phosphates and superphosphatés used as fertilizers contain arsenic in amounts up to $2 \%$ of the phosphorous present in the fertilizer (Swaine 1962 in Bowen 1966). Many farm pesticides and herbicides are arsenicals. Thus, leaching of arsenic compounds from farm areas could explain the appearance of arsenic in the river during the fall and winter. Also, some aresenic minerals in soils are soluble in water (Vinogradov 1959).

The sample taken from Farm Ditch X011 (page 113)

had the highest arsenic concentration $(11.8 \mu \mathrm{g} / I)$ of any water sample, which further suggests that farm chemicals may have been responsible for the aresenic in the river above Rood Road Station.

Rock Creek had detectable amounts of arsenic in May 1973, and Farmington Station showed arsenic in July 1973 when the flow at this station was derived from Rock Creek and was essentially sewage effluents. One of the sources of arsenic in domestic waste water is household detergents. Some common brands exceed $30 \mu \mathrm{g} / \mathrm{g}$ (ppm) arsenic (Zwick 1971). Cadmium and Molybdenum. Molybdenum was detected only twice (Table V). Both times the concentrations were at the detection level of $10 \mu \mathrm{g} / 1$.

Cadmium was found at Rood Road Station in March 1973, in the snow of December 1972, and in Rock Creek in May 1973. 
TABLE V

TRACE ELEMENT CONCENTRATIONS IN

SELECTED WATER SAMPLES FROM

THE TUALATIN RIVER

(MICROGRAMS PER LITER)

STATION

October 28,1972

Gaston
Dilley
Cornelius
Hillsboro
Rood Road
Farmington

December 18,1972

\section{Gaston}

Dilley

Connelius

Hillsboro

Rood Road

Farmington

March 23, 1973

Gaston

Dilley

Cornelius

Hillsboro

Rood Road

Farmington
As $\mathrm{Cd}$ Cr $\mathrm{Co}$ Cu $\mathrm{Fe} \quad \mathrm{Pb}$ Mo $\quad \mathrm{K}$ Ni

$\mathrm{Zn}$

$\begin{array}{rrrrrrrrrrr}1.9 & - & 4 & 2 & 6 & 4030 & 8 & - & 800 & 3 & 10 \\ 0.8 & - & 4 & 2 & 6 & 3530 & 5 & - & 900 & 3 & 9 \\ 0.8 & - & - & 1 & 2 & 590 & 8 & - & 800 & - & 3 \\ 2.2 & - & - & 1 & 1 & 540 & 8 & - & 1300 & - & 2 \\ - & - & 1 & 2 & 2 & 790 & 5 & - & 1900 & 3 & 3 \\ 0.2 & - & 2 & 2 & 7 & 1340 & 8 & - & 3300 & 3 & 11\end{array}$

$\begin{array}{rrrrrrrrrrr}- & - & 21 & 13 & 51 & 24990 & 13 & - & 1900 & 19 & 50 \\ \mathrm{~T} & - & 15 & 8 & 27 & 15490 & 13 & - & 1600 & 12 & 34 \\ 0.6 & - & 21 & 11 & 38 & 22990 & 18 & - & 2500 & 18 & 50 \\ - & - & 15 & 8 & 21 & 16490 & 13 & - & 2500 & 12 & 41 \\ - & - & 10 & 6 & 15 & 12490 & 13 & \mathrm{~T} & 2200 & 9 & 37 \\ - & - & 9 & 3 & 14 & 6990 & 15 & - & 2300 & 7 & 29\end{array}$

$\begin{array}{rrrrrrrr}- & - & 1 & 1 & 2 & 1109 & - & - \\ - & - & 1 & 2 & 2 & 1940 & - & - \\ - & - & 1 & 2 & 4 & 1840 & 8 & - \\ 0.2 & - & 4 & 2 & 2 & 1840 & 8 & - \\ - & 1 & 1 & 2 & 3 & 1590 & 10 & - \\ - & - & 2 & 2 & 4 & 1690 & 8 & -\end{array}$

400

500

600

800

800

1000

$\begin{array}{rr}2 & 9 \\ 2 & 11 \\ 3 & 12 \\ 2 & 12 \\ 2 & 9 \\ 3 & 14\end{array}$




\begin{tabular}{|c|c|c|c|c|c|c|c|c|c|c|c|}
\hline \multirow{2}{*}{ STATION } & \multirow[b]{2}{*}{ As } & \multirow[b]{2}{*}{$\mathrm{Cd}$} & \multirow[b]{2}{*}{$\mathrm{Cr}$} & \multirow[b]{2}{*}{ Co } & \multicolumn{2}{|c|}{ (MICROGRAMS } & \multicolumn{3}{|c|}{ PER LITER) } & \multirow[b]{2}{*}{$\mathrm{Ni}$} & \multirow[b]{2}{*}{$\mathrm{Zn}$} \\
\hline & & & & & $\mathrm{Cu}$ & $\mathrm{Fe}$ & $\mathrm{Pb}$ & Mo & K & & \\
\hline \multicolumn{12}{|l|}{ July 21, 1973} \\
\hline $\begin{array}{l}\text { Gaston } \\
\text { Dilley } \\
\text { Cornelius } \\
\text { Hillsboro } \\
\text { Rood Road } \\
\text { Farmington }\end{array}$ & $\begin{array}{l}- \\
- \\
- \\
- \\
T\end{array}$ & $\begin{array}{l}- \\
\overline{-} \\
\overline{-} \\
\overline{-}\end{array}$ & $\begin{array}{r}12 \\
T \\
1 \\
1 \\
1 \\
2\end{array}$ & $\begin{array}{l}- \\
- \\
2 \\
2 \\
2 \\
4\end{array}$ & $\begin{array}{l}2 \\
2 \\
2 \\
2 \\
4 \\
8\end{array}$ & $\begin{array}{r}440 \\
340 \\
440 \\
590 \\
990 \\
1440\end{array}$ & $\begin{array}{r}\overline{8} \\
8 \\
- \\
\overline{0}\end{array}$ & $\begin{array}{l}- \\
- \\
- \\
\bar{T}\end{array}$ & $\begin{array}{r}300 \\
500 \\
900 \\
1300 \\
1500 \\
5000\end{array}$ & $\begin{array}{l}2 \\
3 \\
2 \\
2 \\
3 \\
7\end{array}$ & $\begin{array}{r}3 \\
.13 \\
9 \\
15 \\
15 \\
13\end{array}$ \\
\hline \multicolumn{12}{|l|}{ December 12, 1972} \\
\hline $\begin{array}{l}\text { Melted snow } \\
\text { (Suburban Hillsboro) }\end{array}$ & - & $\mathrm{T}$ & 1 & 1 & 16 & 1440 & 56 & - & 400 & 5 & 44 \\
\hline \multicolumn{12}{|l|}{ May 5, 1973} \\
\hline Rock Creek & 2.0 & 4 & 139 & 3 & 42 & 940 & 23 & - & 3500 & 7 & 21 \\
\hline \multicolumn{12}{|l|}{ May 25, 1973} \\
\hline Rock Creek & 2.6 & - & 17 & 2 & 24 & 1010 & 33 & - & 3900 & 11 & 27 \\
\hline \multicolumn{12}{|l|}{ June 19,1973} \\
\hline Farm Ditch X011 & 11.8 & - & 1 & 3 & 4 & 810 & 10 & - & 1800 & 3 & 54 \\
\hline Detection Levels & - & 1 & 1 & 1 & - & 10 & 5 & 10 & 100 & 1. & 1 \\
\hline
\end{tabular}


There is no apparent explanation for the cadmium at Rood Road Station.

The cadmium in the sample of snow was at the detection level of $1 \mathrm{\mu g} / \mathrm{l}$. While it is possible that analytical error accounts for the cadmium in the sample of snow, potential sources of cadmium could be aerosols from tire wear on the streets, automotive lubricating and diesel oils and household heating oils (Lagerwerff and Specht 1970). The snow sample was taken from a suburban area surrounded by busy streets and residences, and thus may not be relative to the total watershed.

There were higher concentrations of cadmium, lead, chromium, and copper in Rock Creek than in the Tualatin River (Table V). In the Rock Creek drainage basin there are at least two industrial sources of metallic discharges. One of these is an electronic equipment manufacturer (Tektronix Inc.) which is the largest industrial complex in the basin. The other source is a battery recovery plant. These industtries may be responsible for some of the trace elements in Rock Creek.

Chromium. Chromium was above the $1 \mu \mathrm{g} / \mathrm{I}$ detection level in all but two samples of river water. During the December 1972 flood there was from 4 to 10 times more chromium present than at other times of the year. This was due to the increased sediment load that the flood waters carried. Concentrations of zinc, iron, nickel, copper, cobalt, and 
chromium were higher during the flood (Table V).

The foothills of the Coast Range near Gaston and Dilley are made up of red soils (Watson et al. 1923). Vinogradov (1959) states that the concentration of chromium in soils is usually parallel to the concentration of iron, but that in red soils the chromium is low despite the concentration of iron. In the December flood waters the amounts of iron and chromium were parallel, but the concentration of iron was 1000 times that of the chromium.

Rock Creek on 5 May 1973 had $139 \mu \mathrm{g} / 1$ chromium and on May 25 it had $17 \mathrm{~g} / 1$ chromium. The cause of these higher concentrations is probably industrial (see cadmium). There is no apparent explanation for the $12 \mu \mathrm{g} / 1$ concentration of chromium at Gaston Station in July 1973.

Cobalt. Cobalt was found in detectable amounts (detection at $I \mu \mathrm{g} / I$ ) in the river at all times except during July 1973 at Gaston and Dilley Stations. Only during the December 1972 flood were the concentrations of cobalt above $4 \mu \mathrm{g} / \mathrm{l}$ (Table V). Neither Rock Creek nor Farm Ditch X01l showed a concentration different from the river.

Copper. Soluble copper was present in all water samples. The highest concentrations of copper were found in the river during the December 1972 flood and were likely due to the increased sediment load the flood waters carried. In the other seasons, the copper concentrations were highest at Farmington Station, and those in Rock Creek were two times 
those of the river.

Since the concentration of copper in Farm Ditch X011 was similar to the river, it is unlikely that copper concentrations in the Tualatin are from agricultural chemicals.

In Rock Creek soluble copper may have been present from the industrial sources (see cadmium), however, copper is also associated with the effluents of sewage treatment plants (Analemann 1973). The concentration of copper in effluents may be as much as $40 . \mu \mathrm{g} / 1$ (Pound and Crites 1973). Human excreta contributes to this source (Dugan 1966). The copper in the sludges of some sewage treatment plants may be 40 times greater than that present in soils (Berrow and Webber 1972). Soluble copper could have been leaching from sewage sludges or be coming from industrial sources to affect Rock Creek and the Tualatin at Farmington Station (Table V, page 70 ).

Iron. Total iron concentration at Gaston was high during the December 1972 flood (Table V). The hills of the southwestern part of the Tualatin Valley are high in iron (Schlicker and Deacon 1967).

The amount of iron in Farm Ditch X011 did not differ greatly from the river itself during July 1973. This is notable since the iron concentrations in phosphorous fertilizers can be from 10 to $40 \%$ of the phosphorous concentrations (Swaine 1962 in Bowen 1966). 
The greatest impact on the river as far as the concentrations of iron are concerned is the natural minerals in the surrounding watershed and their leaching into the river.

Lead. Lead occurred in the Tualatin River above the $5 \mu \mathrm{g} / \mathrm{l}$ detection level at all stations in October and December 1972. There was no detectable lead at Gaston and Dilley Stations in March 1973, non at Dilley, Hillsboro or Rood Road Stations in July 1973 (Table V).

During the December 1972 flood when the lead concentrations in the river were the highest ( $18 \mu \mathrm{g} / I$ ) the alkalinity of the Tualatin River ranged from 10 to $15 \mathrm{mg} / \mathrm{l}$ as $\mathrm{CaCO}_{3} \cdot$ Lead is very soluble in soft water; at $\mathrm{pH} 6.5$ and an alkalinity less than $30 \mathrm{mg} / \mathrm{l}$ as $\mathrm{HCO}_{3}$, the concentrations of leas can exceed $100 \mu \mathrm{g} / \mathrm{I}$ (Hem and Duran 19973). Pitt and Amy (1973) state that dissolved lead in soft water is very toxic to aquatic organisms.

Lead is not easily removed from the mineral part of the soil; it has a strong affinity for humus and so organic matter plays an important role in the migration of lead in the ecosystem (Vinogradov 1959). Lead has been found to become highly mobile in water when fermenting plant material is added (Leland et al. 1971). This is noted since the Tualatin River contains much organic matter most of the year.

The lead in Rock Creek was more likely to have come from an industrial source than from domestic wastes, since lead in sewage treatment plant sludges is not very soluble 
(mean solubility of less than $7 \%$ )(Berrow and Webber 1972).

The water in Farm Ditch XOII was not statistically different from the river.

The $56 \mu \mathrm{g} / \mathrm{l}$ lead found in the December 1972 snow sample could be related to the use of automobiles. Lazarus et al. (1970) state that lead, zinc, copper, iron and manganese in atmospheric precipitation is primarily from human activities . and there is a iigh correlation coefficient between lead in the precipitation and the consumption of gasoline. Water from snow contains more lead than an equal amount of rainwater because the snow flakes have a greater surface area and fall more slowly through the air thereby picking up more lead (Sci. News 1973). The concentration of lead in the snow was four times that of the water in the river which resulted from the flood caused by the snow melt.

Potassium. Potassium is not a trace element; it occurs in water in concentrations greater than $1 \mathrm{mg} / \mathrm{l}$. Potassium is a major component of many farm fertilizers and might indicate the role of agriculture in relation to the water quality of the Tualatin River. However, many minerals in the Tualatin Valley contain potassium (Schlicker and Deacon 1967).

The concentration of potassium increased downstream except during the December flood. Leaching of minerals is a likely reason for this downstream increase, since potassium salts are readily soluble in water. 
Rock Creek in May and Farmington in July had the highest concentrations of potassium (Table V). Potassium is a constituent of human excreta (Bowen 1966) as wiell as minerals and farm fertilizers.

The concentration of potassium in Farm Ditch X01I was about the same as the river at Hillsboro Station in the summer, but it was only half that of. Rock Creek. There could be some leaching of farm chemicals into the river, but it appears that the natural weathering of soil minerals is the greatest source of potassium in the Tualatin River and that industrial or domestic waste effluents also contribute potassium.

Nickel. The concentration of nickel in the Tualatin River paralleled that of iron in a ratio of $1 \mathrm{Ni}$ to $1000 \mathrm{Fe}$ during the December 1972 flood. Since nickel is associated with iron in soils (Vinogradov 1959) the higher concentrations during the flood were probably due to leaching and sediment transport by the flood water (Table V).

Nickel is an atmospheric contaminant from automobiles (Lagerwerff and Specht 1970) but what contribution this source had on the nickel in the snowfall in unknown. The concentration of nickel in Farm Ditch X011 did not differ from the main river.

Nickel in sewage sludges is soluble (Berrow and Webber 1972) and therefore would be discharged into the river with sewage effluents. The concentrations of nickel in Rock 
Creek and at Farmingtón Station in July 1973 may reflect this impact (Table V). The source of nickel was probably industrial, because humáns excrete little nickel (Bowen $1966)$

Noteworthy is the fact that the ratio of nickel to cobalt in the Tualatin River is about one to one, while the usual ratio is about 2 to 10 nickel for every cobalt (Benoit 1969).

Zinc. In the Tualatin River concentrations of zinc followed those of iron ( 1 zinc to 500 iron) during the December flood. Because the concentrations of zinc correspond to the concentrations of ferric oxides in red soils (Vinogradov 1959), leaching of minerals in the watershed and zinc from the sediments carried by the flood were the probable sources of zinc. Clays and organic matter tend to fix zinc to their surfaces; thus, on the floodplain when the velocity of the water decreases and turbidity is less, the concentrations of zinc are reduced (Figure 19, Table V).

Zinc compounds in soils are dissolved by acid rain water and are carried in soil waters, which can dissolve large amounts of zinc (Vinogradov 1959). The average pH of the rain in the Willamette Valley which includes the Tualatin Valley is 4.5 (Klein 1974).

Effluents from sewage treatment plants contain zinc (Berrow and Webber 1972); some as much as $60 \mu \mathrm{g} / \mathrm{I} \mathrm{Zn}$ (Pound E Crites 1973). Possible sources of this zinc are human 
excreta (Bowen 1966), galvanized roof flashing and gutters which are dissolved by the acid rains, pharmaceuticals, cosmetics and rubber (Berrow and Webber 1972). Zinc is often a part of street run-off that enters a sewage treatment plant as part of the combined storm and sanitary sewers such as occur in parts of Hillsboro. Pitt and Amy (1973) found that there was $1.4 \mathrm{mg} / 1$ zinc in street run-off; due in part, to the wear of tires on the street surface (Lagerwerff $\varepsilon$ Specht $1970)$.

There were $44 \mu \mathrm{g} / 1$ zinc in the snow sample from the December 1972 snowfall. Zinc is one of the elements that is increased in the atmosphere as a result of human activity. The average concentration of zinc in the precipitation over the United States is $107 \mu g / I$ (Lazurus et al. 1970).

The $54 \mathrm{\mu g} / \mathrm{l}$ zinc in the water from Farm Ditch X0II was not explainable. It is 3 to 4 times the concentration of zinc in the river in the spring or summer when the water is not turbid with mineral sediments from flooding.

Zinc concentrations in Rock Creek were probably due to leaching of natural minerals, and secondarily to the effluents from sewage plants.

Inorganic nitrogen

In running waters the primary forms of inorganic nitrogen are ammonium, nitrite, and nitrate, with the nitrate ion being the most prevalent form (Hynes 1970; Brezonic 1973). 
In unpolluted waters ammonium ion concentrations are less than $1 \mathrm{mg} / \mathrm{l}$ (Reid 196I).

Concentrations of $0.30 \mathrm{mg} / \mathrm{I} \mathrm{N}$ are sufficient to produce algal blooms if no other factor is limiting (Sawyer 1947 and Mackenthum 1965). Nitrate-nitrogen seems to be the preferred form for higher plants and a few algae, however, there is considerable evidence that ammonium-nitrogen is the preferred form for planktonic assimilation since it is already in the reduced form (Brezonik 1973).

In the Tualatin River the concentrations of inorganic nitrogen species indicate that at different times and at different stations there are all possibilities from nutrient limitations to toxicity or growth inhibition.

Nitrate-nitrogen concentrations may have been limiting to algal growth at Gaston, Dilley, and Hillsboro Stations during the latter part of the summer when the concentrations approached zero (Figure 24). However, at this time, there was a bloom of Microcystis sp. at Hillsboro Station. No algal blooms occurred at the three upstream stations, (Dilley had a temporary, man-caused, MeZosira varians bloom behind a small sandbag dam of the US Geological Survey.) and in fact Cornelius Station had a decrease in the net plankton populations (Table VIII, page 107). The amounts of nutrients actually in solution in the river may be small due to rapid uptake by the organisms. Nutrient recycling rates are often of greater ecological importance in supporting 


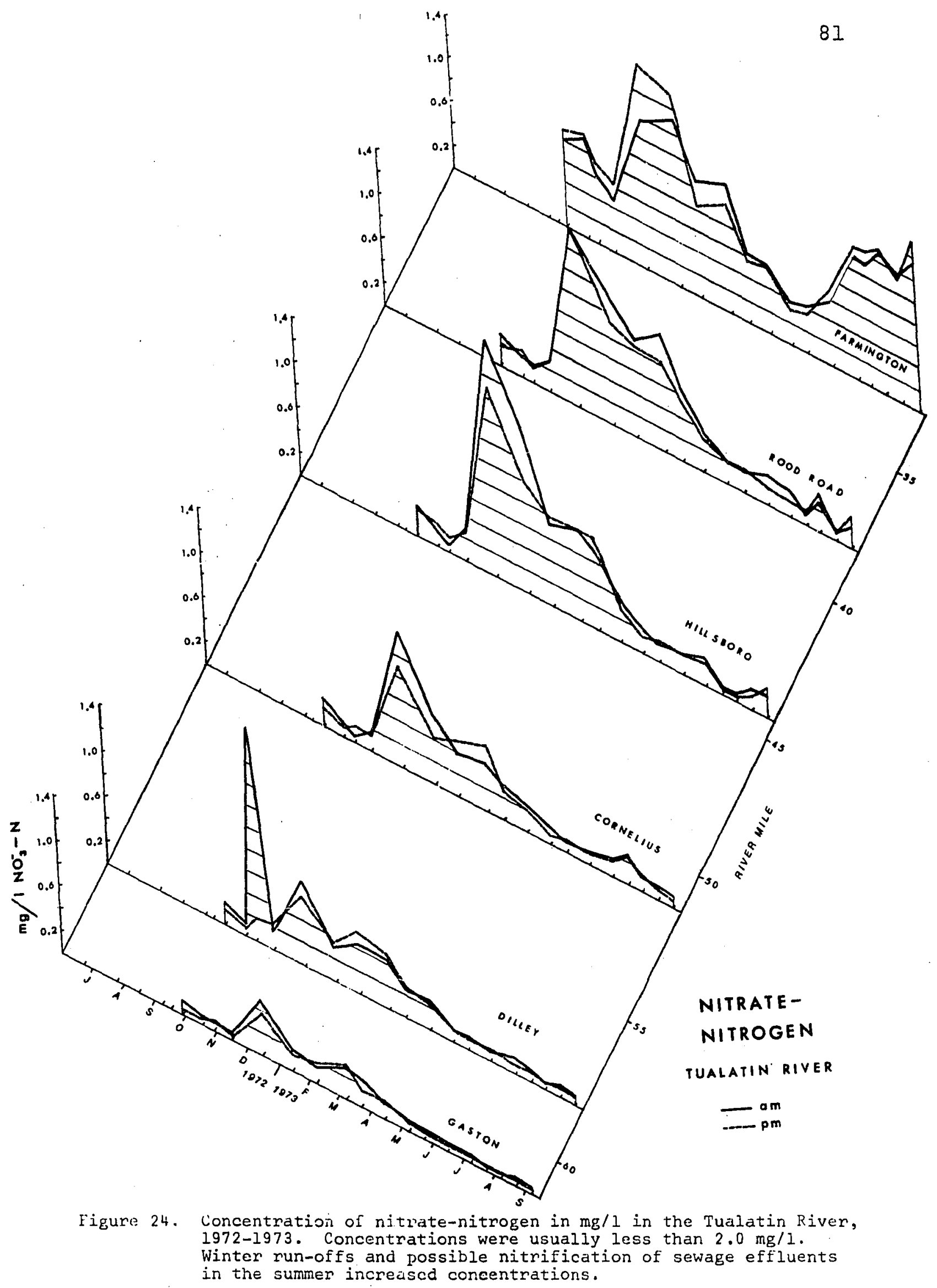


photosynthetic organisms than the actual concentrations of nutrients in the water (Hynes 1970).

The highest nitrate-nitrogen concentrations in the river were observed during the winter floods. During floods the concentrations of nitrate-nitrogen may be expected to increase significantly (Reid 1961). At all stations except Farmington the highest concentrations of ammonium-nitrogen were also during the floods, however, concentrations were only slightly over I $\mathrm{mg} / \mathrm{l}$ (Figure 25 ).

Normally the ground in the Tualatin Valley does not freeze deeply, but both of the winter floods during this study were preceeded by a period of cold weather which froze the ground for over a week before the floods. Frozen soils do not allow percolation of water, and so a large portion of the soluble nutrients in the soil's surface are washed away in the run-off and increase the concentrations of these nutrients in the receiving stream (Biggar and Corry 1969). Nutrient uptake of higher plants on agricultural land is depressed by low temperatures and low insolation, so that microbial action within the soil allows inorganic nitrogen products to accumulate. Nitrates are leached the most, because the ammonium ion can bind to cation sites on soil particles (Biggar and Corey 1969). Nitrates can be formed in cool water, even under ice, and in non-frozen soils (Alexander 1971). The first flood in December 1972 probably washed away some of the accumulated inorganic nitrogen from 


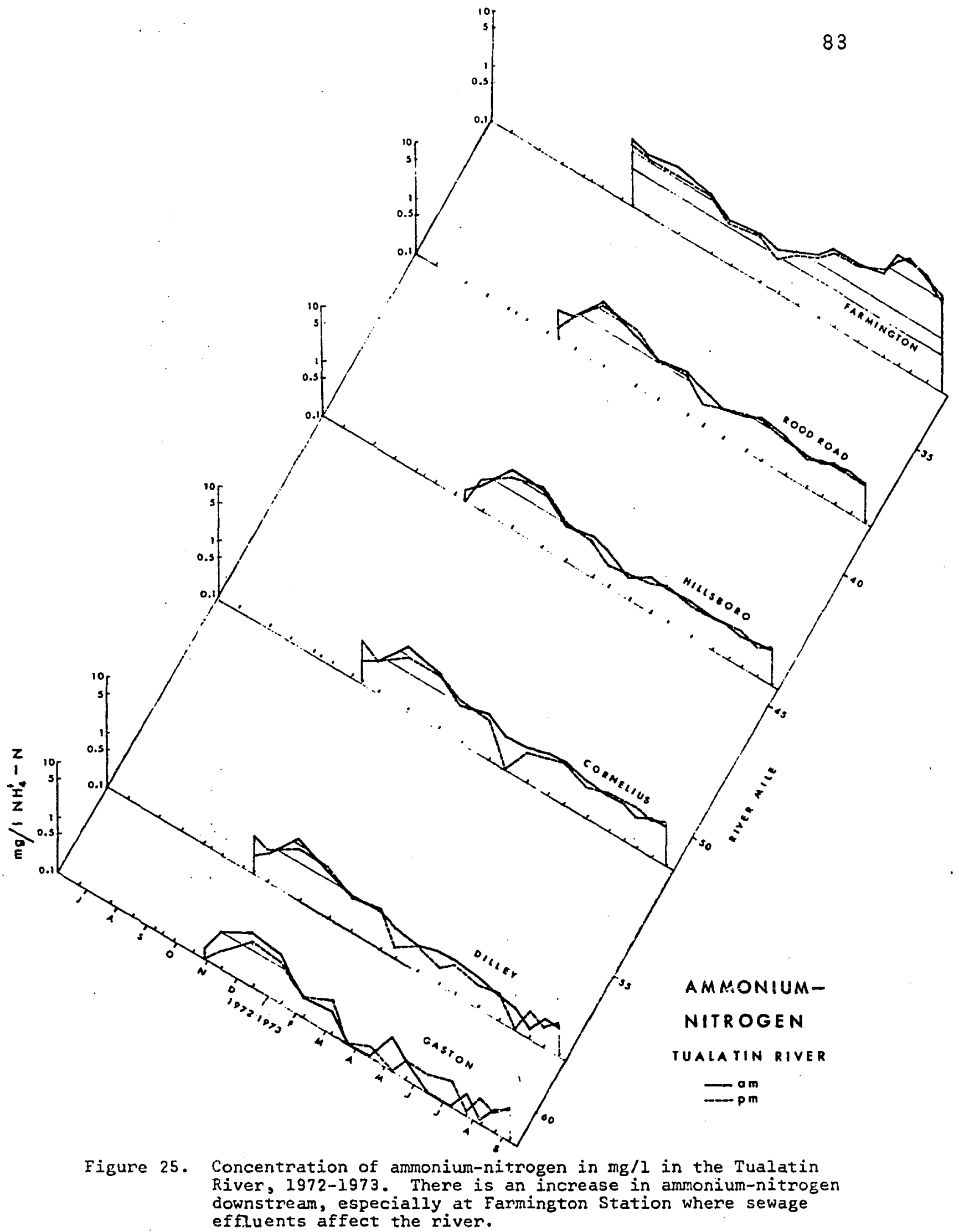


the land areas and the January 1973 flood washed out more.

After the winter high the ammonium-nitrogen concentrations remained fairly stable (below $0.5 \mathrm{mg} / \mathrm{l}$ ) throughout the summer except at Farmington Station and in Rock Creek (Figure 18).

There was more inorganic nitrogen at Farmington Station in the summer because the flow of Rock Creek upstream was primarily sewage effluents which can contain 10 to $20 \mathrm{mg} / \mathrm{I}$ ammonium-nitrogen (Wezernak and Gannon 1967). From June to September 1973 the concentration of ammonium-nitrogen in Rock Creek was between 10 and $20 \mathrm{mg} / 1$ (Figure 18). At the same time the-river at Farmington Station had concentrations of ammonium-nitrogen between 2 and $12 \mathrm{mg} / \mathrm{l}$ (Figure 25).

There is strong evidence that the ammonium-nitrogen in the mainstem river below Rock Creek was being nitrified to nitrates from June to September 1973 (Aleem and Alexander 1958; Alexander 1971; Beckman, et al. 1972; Gaudy 1972; Goering 1972; Hoffman and Lees 1953; Montgomery and Borne 1966; Painter 1970; Stratton and McCarty 1967; Wezernak and Gannon 1958). There seem to be no other reasonable explanation for the increase in nitrate-nitrogen at Farmington Station (Figure 24). In polluted water then ammoniumnitrogen concentrations are greater than $10 \mu \mathrm{M}(0.14 \mathrm{mg}$ $\left.\mathrm{NH}_{4}^{+}-\mathrm{N} / 1\right)$, nitrification and phytoplankton growth can occur simultaneously (Goering 1972). Hence at Farmington Station even though there were algal blooms iTabIe VIII, page 
107) occurring, nitrification was also possible.

There is a possibility that the high amnonium-nitrogen concentrations in Rock Creek (Figure 18, page 52) in the summer are partially responsible for the reduced fish diversity and abundance in the Tualatin River at Farmington Station. Local fishermen have complained in recent years about the changes in the fish species and the reduced catch from the river at Farmington. Public access to the river is limited and few local people are consumers of the warm-water species present so that overfishing is not a likely explanation for the decreased catch.

Short-term laboratory studies show that un-ionized ammonia concentrations are lethal at $0.2 \mathrm{mg} \mathrm{NH}_{3} / 1$ for trout (Salmo spp.) and at $2.0 \mathrm{mg} \mathrm{NH}_{3} / 1$ for carp (Cyprinus carpio) (EIFAC 1973). However, a concentration of $0.025 \mathrm{mg}$ un-ionized $\mathrm{NH}_{3} / I$ is probably the maximum which fish and invertebrate organisms are able to tolerate for extended periods and show no deleterious effects. At $\mathrm{pH} 7.0$ the amount of total (ammonium and ammonia) ammonia-nitrogen which would correspond to $0.025 \mathrm{mg} \mathrm{NH} / 1$ ( $12 \%$ of the $\mathrm{LC}_{50} 0.2 \mathrm{mg} / 1$ ) un-ionized ammonia is $9.1 \mathrm{mg} / \mathrm{l}$ at $1.5 \mathrm{C}, 6.3 \mathrm{~m} / \mathrm{I}$ at $20 \mathrm{C}$, and $4.4 \mathrm{mg} / \mathrm{I}$ at $25 \mathrm{C}$ (EIFAC 1973; FWPCA 1968).

Rock Creek ammonium-nitrogen values were above the $15 \mathrm{C}$ $9.1 \mathrm{mg} / \mathrm{I}$ limits from June until September 1973. No fish of any kind were ever seen in Rock Creek during this study period. 
From mid-July to mid-August 1973 at Farmington Station aminonium-nitrogen concentrations exceeded the EIFAC limits at least part of the day, and on August 4 the ammonium-nitrogen concentrations were three times the suggested maximum.

Common carp and other coarse fish are able to acclimate to sublethal concentrations and may, therëfore, be able to withstand concentrations of ammonium-nitrogen for short periods that would be lethal to more sensative fish (EIFAC 1973). But they will avoid such concentrations for long term periods, and will migrate to areas where ammoniumnitrogen concentrations are more hospitable thus reducing the fish available for fishermen. This might be the case at Farmington Station.

Nitrogen fixation was improbable at Farmington. The nitrogen fixing algae either were not present or in the case of Anabaena sp. hetercysts were rare.

Phosphate

Rates of phosphorous removal from streams by biological activity vary from river to river, within sections of a river, and with the seasons (Keup 1968). Phosphorous tends to be fixed to suspended matter, which is not uniformly distributed in the water mass. Since solids are greater near streambeds or floating, mid-depth samples may underestimate phosphorous. No single factor governs quantities of phosphorous in a stream (Keup 1968). 
In many aquatic ecosystems phosphorous presents a mosaic of alternating limitations, non-limitation, variability of limiting concentrations and inhibition, depending on the organisms involved (Clesceri 1973). Other factors may be the use of organic phosphorous fractions.by the algae and the possibility of a catalytic compound (phosphorous-sparing compound (Hutchison 1950, page 734)) in the water which allows more effective use of low concentrations of phosphorous (Rohde 1948 cited by Clesceri 1973). Thus, the needs for inorganic phosphorous and nitrogen for algal growth are 10 to 100 times greater in laboratory studies than in in situ field requirements (Clesceri 1973).

In this study phosphorous was measured as total dissolved and suspended acid-hydrolyzable phosphates (APHA 1971). This analytical procedure was adopted as the best estimate of the amount of phosphorous potentially available to aquatic algae. These acid-hyrolyzable phosphates hydrolyze to ortho-phosphates. The hydrolysis may take weeks in clean, neutral water, but it is much more rapid in sewage or under acid conditions (Devey and Harkness 1973). Spot checks of ortho-phosphate concentrations in 1973 always showed greater than $0.10 \mathrm{mg} / \mathrm{l}$.

In the winter the hydrology and turbidity of the water have a greater influence on the amount of phosphorous in the Tualatin Riven than does any biological activity. Except for Farmington Station the concentrations of 
phosphate increased greatly with the December 1972 flood and even more with the one in January 1973 (Figure 26). Farmington Station did not fit this pattern for a number of reasons. One factor was the greater dilution of the sewage effluents from Rock Creek by the flood waters; another was the time that the water mass took to move downstream in the flood. The main impact of the floods had not reached either Rood Road or Farmington Stations at the time of sampling. The decrease in turbidity also influenced the phosphate concentrations at Farmington.

From February to September 1973 the stations upstream from Rood Road Station had levels of poly-phosphate that did not change much either diunnally or seasonally. The slightly higher concentrations of poly-phosphate at Rood Road Station relative to the four upstream stations reflected the effluents from the city of Hillsboro sewage treatment plant. There was a drop in the amount of phosphate at Rood Road in September when the flow was reestablished after summer irrigation demands decreased.

There was a steady increase of poly-phosphate at Farmington Station beginning in late March. This increase was probably due to the reduced flow of water in the mainstem Tualatin River, which would have diluted the Rock Creek effluents, rather than to any changes in the absolute amounts of poly-phosphate, because when the flow of the river returned the concentrations of poly-phosphate declined. 


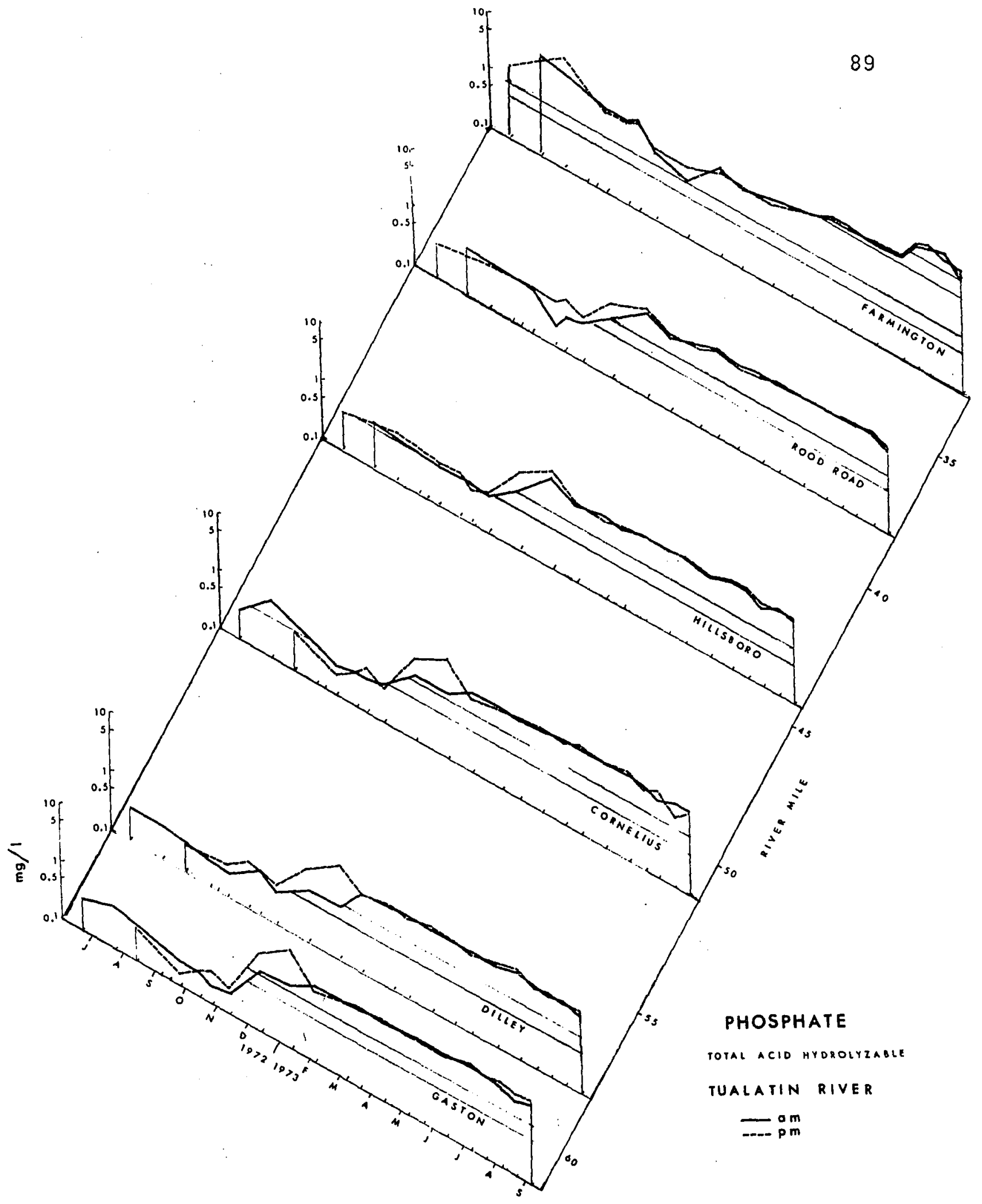

Figure 26. Concentration of acid hydrolyzable phosphate in $\mathrm{mg} / \mathrm{l}$ from unfiltered water samples in the l'ualatin River, 1972-1973. The introduction of sewage effluents above Farmington Station caused higher concentrations at that station, although a natural source of phosphates upstream was indicated. 
Sampling of Rock Ćreek was started in April 1973. In Rock Creek phosphate concentrations rose to a maximum in mid-July when there was no natural flow in Rock Creek (Figure 18, page 52 ). The concentrations were those to be expected from sewage treatment plant effluents.

At the time of this study many phosphate products used by humans have a poly-phosphate base, including detergents. In the United States 40 to $60 \%$ of the heavy duty detergents, 2 to $15 \%$ of the light duty detergents, and 15 to $25 \%$ of the laundry detergents consist of poly-phosphates (Devey and Harkness 1973). The increase in acid-hydrolyzable phosphates at Farmington Station may reflect the addition of phosphorous derived from detergents.

The concentrations of poly-phosphate in the Tualatin River for the year 1973 were so high that it is improbable that phosphates limited algal growth. By the same token, the biological activity does not seem to have affected the phosphate concentrations.

\section{Inorganic Carbon}

Inorganic carbon (dissolved $\mathrm{CO}_{2}, \mathrm{HCO}_{3}^{-}$, or $\mathrm{CO}_{3}^{-}$) is used by algae and some bacteria as a nutrient source. Within the $\mathrm{pH}$ range of the Tualatin River, the bicarbonate ion is the principal form of inorganic carbon.

According to Watson et al. (1923) the soils of the Tualatin valley do not have a source of natural inorganic 
carbon, thus, the natural flow of the river has little inorganic carbon. This is also indicated by the low alkalinities of the river water.

The amount of inorganic carbon present can indicate the potential of an aquatic ecosystem to support algal productivity as well as the amount of bacteriological decomposition occuring. Low concentrations of inorganic carbon indicate either a lack of a source or depletion of the supply because of biological processes. High inorganic carbon shows a potential for high algal productivity or bacterial nitrification if other conditions for growth are appropriate. The greater the difference between the inorganic concentrations at dawn and at noon, the greater the metabolic activity for that day. If the morning readings are higher that those at noon the production of biomass exceeds decomposition, and vice versa.

Generally inorganic carbon concentrations were lowest in the winter when alkalinities were low and flow was high (Figure 27). Concentrations of inorganic carbon were higher downstream, except at Farmington Station during the summer. Except for August, there was only a slight difference between the dawn and noon inorganic carbon concentrations in the main river. Concentrations were more variable in Rock Creek than in the main river throughout the summer (Figure 18. 


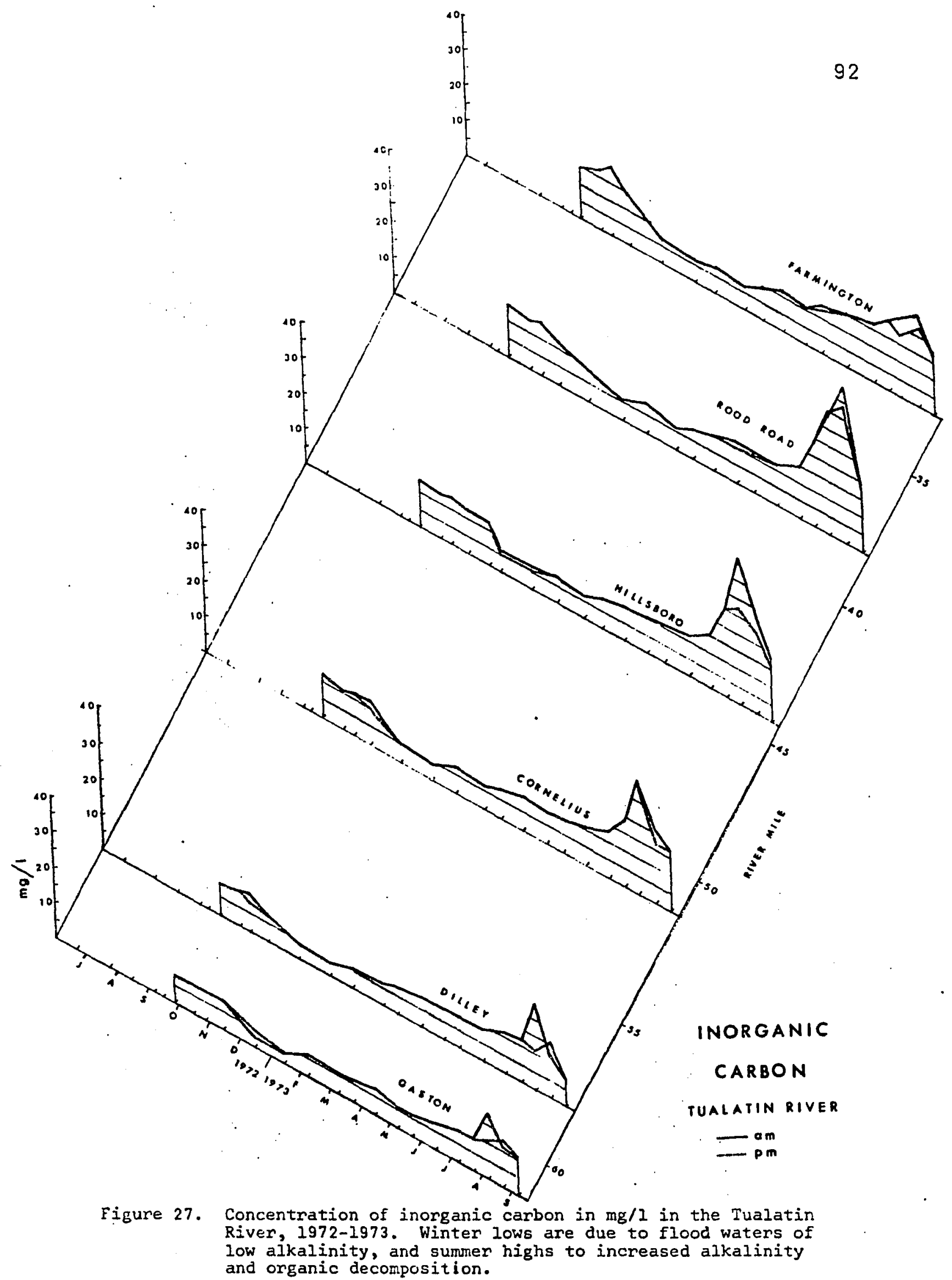


Alkalinity values for the river were the highest during the summer and thus the highest concentrations of inorganic carbon were in August. The decomposition of organic matter would have to have been high to replace the inorganic carbon used by the algae to photo-synthesize and create the large algal population in the river at that time.

If the process of photosynthesis is the major reason for inorganic carbon uptake, the concentrations of inorganic carbon and dissolved oxygen should be inversely related (see equation, page 95). The dissolved oxygen should increase with algal photosynthesis to an afternoon high, while the inorganic carbon decreases to an afternoon low. The inorganic carbon would be high in the mornings and the dissolved oxygen would be low due to biological respiration. If during the daylight hours respiration and decomposition are greater than photosynthesis, the inorganic carbon supply should increase. Nitrification uses both dissolved oxygen and bicarbonate ions to oxidize ammonia (see discussion on inorganic nitrogen).

At Rood Road Station on 4 August 1973 the temperature of the water in the non-flowing pools was 31C. The BOD values for the day were also high (5.I and $4.4 \mathrm{mg} / \mathrm{I})$ indicating that decomposition of organics was high. The dissolved oxygen in the water increased $2.3 \mathrm{mg} / \mathrm{I}$ for the day, but the inorganic carbon concentration increased by 5.5 $\mathrm{mg} / I$ to ar all time high of $43.8 \mathrm{mg} / \mathrm{I}$ (for this study). 
Inorganic carbon concentrations were high at Gaston and Dilley Stations on 18 August 1973 (Figure 27). At Gaston Station the water was full of fine detritus and Dilley Station had the accumulation of organic matter left in the pool behind the sandbag dam.

At Cornelius Station the variation between dawn and noon was minimal except on 18 August 1973 when inorganic carbon decreased by $3.6 \mathrm{mg} / 1$. On 4 August 1973 all stations showed a decrease in inorganic carbon during the day except Cornelius which showed an increase. The dissolved oxygen at Connelius Station on that day was less than at the adjacent stations. The two stations upstream were influenced by releases from the Trask Reservoir (above Gaston) and there was an algal bloom at Hillsboro downstream.

Cornelius was a heterotrophic station even in the summer. In August 1972 there were many zooplankton present with no apparent algal food supply. Bacteria present in the water quickly clogged a Milipore filter ( $0.45 \mu \mathrm{m}$ pore size) when a water sample was suction filtered. This was not the only time that bacteria and detritus appeared to be the major food source for the zooplankton in the river.

Usually Farmington Station had higher concentrations of inorganic carbon than the upstream stations, but in July and August it had less. This decrease at Farmington at that time was probably due to both photosynthesis and nitrification. 
Ratios of major nutrients

The carbon, nitrogen, and phosphorous requirements for algal protoplasm synthesis are described by the following equation productivity:

$1.3 \times 10^{6} \mathrm{Cal} .+102 \mathrm{CO}_{2}+90 \mathrm{H}_{2} \mathrm{O}+16 \mathrm{NO}_{3}^{-}+\mathrm{PO}_{4}^{--}+$mineral elements $=1.3 \times 10^{4} \mathrm{Cal}$. potential energy in $3258 \mathrm{~g}$ protoplasm $+154 \mathrm{O}_{2}+1.287 \times 10^{6} \mathrm{Cal}$. heat energy dispersed (Odum 1971).

The relative amounts of these three elements present in water can be used to predict which of them is likely to be present in the shortest supply relative to the requirements of the algae. Because phosphorous is present in relatively high concentrations in the Tualatin River, it appears that inorganic nitrogen or inorganic carbon are more likely to limit algal productivity. An analysis of these three nutrients suggests that indeed nitrogen is more likely to be limiting to algal growth.

Nitrogen is defined as the sum of the inorganic nitrogen species. Inorganic carbon was derived from data on alkalinity, $\mathrm{pH}$, and temperature (Saunders et al. 1962). Inorganic phosphorous was calculated from the concentration of the acid-hydrolizable phosphate. The concentrations of the elements were converted to $\mu g-a t / 1$ and are thus their atomic ratios. The assumption was made that organic carbon, organic nitrogen and organic phosphorous did not contribute significantly to the development of the algal biomass. 
The expression above (Odum 1971) implies that nitrogen and phosphorous are present in comparable amounts when their ratio is $16 \mathrm{~N}: 1 \mathrm{P}$. However, Goltermann (1966) has argued that a lower ratio is more appropriate:

"For....the absolute weights of nitrogen and phosphorous should be in a ratio of $10: 1$ to $4: 1$ in water because the same ratio normally appears with the algae. (When polyphosphates are stocked in the algae, the lower ratio will be approached)."

In comparing the nitrogen and phosphorous concentrations in the Tualatin River, the ratio of $4: 1$ was adopted as a guideline. This ratio precludes a bias in favor of phosphorous, which was measured as poly-phosphate rather than orthophosphate. When the ratio of $N: P$ exceeds $4: 1$, it is assumed that phosphorous is more likely to limiting, and when the ratio is less than $4: 1$, nitrogen limitation is more likely.

Figure 28 notes the divergence of $N$ :P ratios between Farmington and the upstream stations which began the first week of May 1973 when summer use of the river for irrigation began.

Figure 28 also shows that in winter $N: P$ ratios were above the 4:1 ratio; however, low insolation and low temperatures were more important in regulating the river ecosystem than the supply of nutrients.

At all stations upstream from Rock Creek, except during the winter, there was relatively more natural phosphorous than nitrogen. Thus at the five upstrearn stations inorganic nitrogen seemed to be the more probable limiting nutrient 


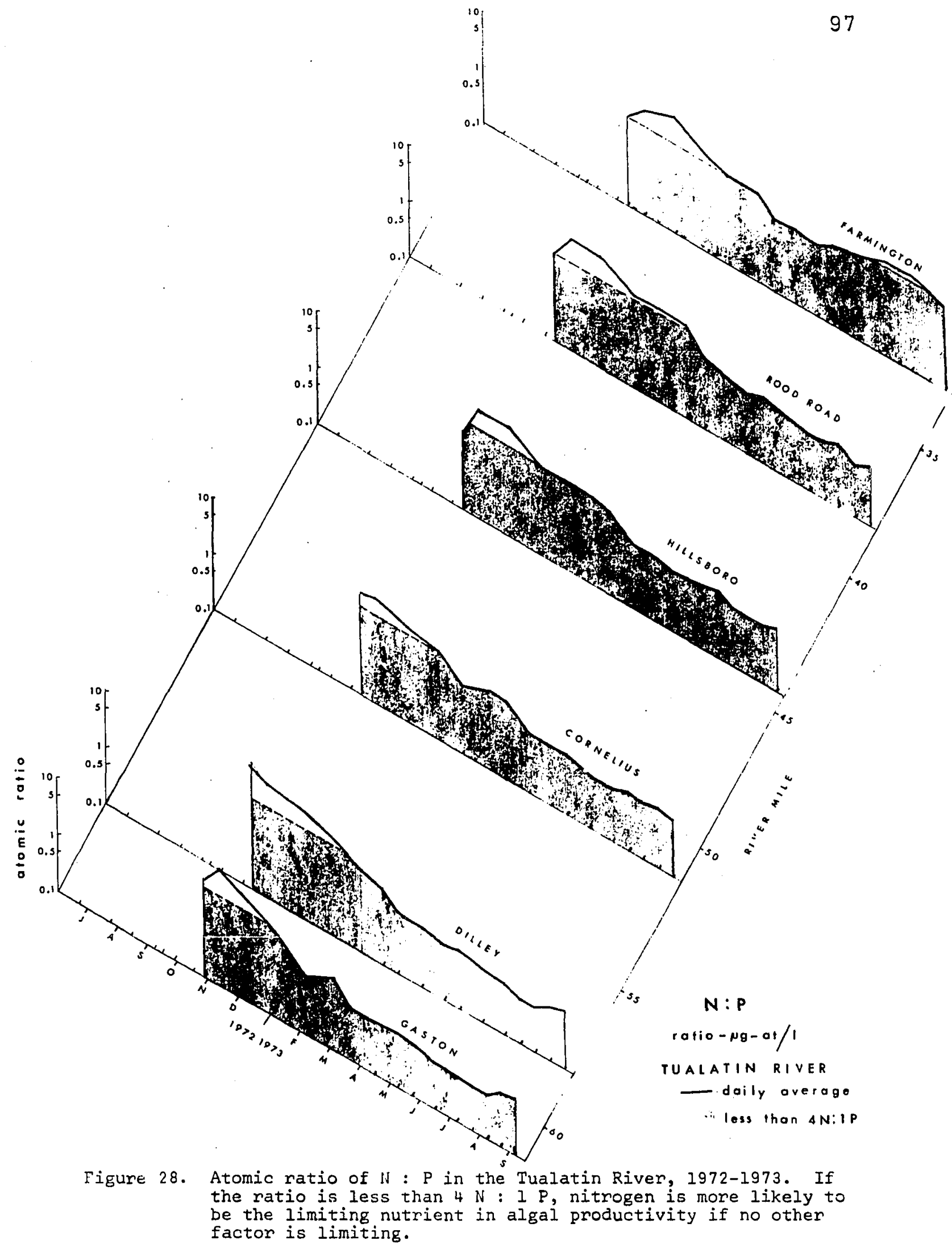


when comparing nitrogen and phosphorous.

In the summer at Farmington Station the $N: P$ ratios showed a deficiency of phosphorous. The relative phosphorous deficiency occurred even though concentrations of poly-phosphates at Farmington Station were 14 to $17 \mathrm{mg} / \mathrm{I}$. Actually this "deficiency" was theoretical and relative for at that time there was a lange algal bloom at Farmington Station.

This $N: P$ ratio analysis indicates that there is enough natural phosphorous entering the river upstream from Gaston to maintain algal growth (sixty percent of the soils in the basin have sufficient phosphorous for agricultural crops (John Leffel, Washington County Agricultural Extension Agent, 1974 pers. comm.). Hence removal of phosphates from effluents probably would not preclude algal blooms in the niver.

Carbon and nitrogen are required by algae in a ratio of approximately $106 \mathrm{C}: 16 \mathrm{~N}$ (Odum 1971). Ratios of C:N greater than 6.62:I mean that nitrogen is the more critical element and possibly limiting; and values of less than $6.62: 1$ mean that carbon has become limiting and is probably the critical element.

Because the Tualatin River was found to have waters low in alkalinity it was possible that inorganic carbon could have been limiting (see alkalinity and inorganic carbon; Appendix D. 
At all stations during the winter floods of 1972-1973, the $C: N$ was well below $6.62: 1$, indicating that the supply of carbon was low and/or the nitrogen concentrations were high (Fịgure 29).

At all the sampling stations the $C: N$ ratios were similar until April 1973. From April the upstream stations showed a steady increase in the C:N ratios until early August; while at Farmington Station $C: N$ ratios were the inverse of the upstream stations. Ratios in Rock Creek were always less than 6.62:1 after April (Figure 18).

At the time of minimal flows the main river above Rock Creek continued to have high $\mathrm{C}: \mathrm{N}$ ratios indicating a possible nitrogen deficiency. The highest ratio, $C: N:: 172: 1$, was at Gaston on 4 August 1973.

Other studies have proposed that nitrogen may be the limiting factor in the summer production of algae in some waters in Oregon (Larson 1974; Youngberg et al. 1971; Larson and Donaldson 1970).

Since no study was done on the conversion of organic carbon to inorganic carbon by the heterotrophic community, no clear statement can be made on carbon limitation. Elevated $B O D$ values indicate that conversion was probable.

The C:N ratios changed seasonally. High flows of winter have low $C: N$ ratios; low flows of summer have high $C: N$ ratios except at Farmington Station and Rock Creek (Figure 29, Figure 18). At these two places the $C: N$ ratios 


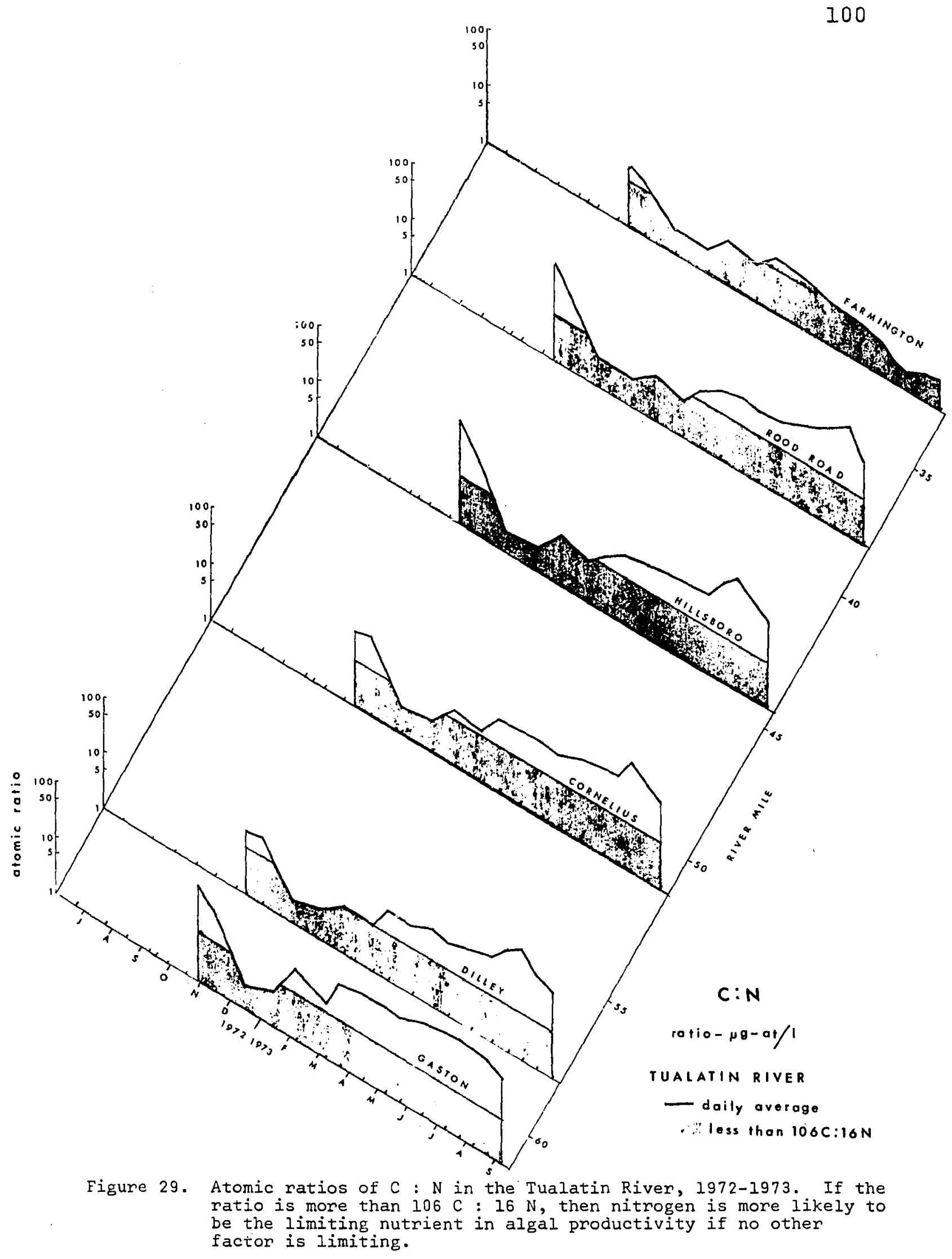


were relatively stable and equal to or less than $6.62: 1$ no matter which season it was (Appendix D).

James and Lee (1974) found that carbon limitation is confined to sewage treatment lagoons and to a few hypereutrophic water bodies. They found that it is probable that the bacterial metabolism of the residual BOD could supply enough $\mathrm{CO}_{2}$ to prevent carbon limitation.

Equally important, the low inorganic carbon supply implied by the low $C: N$ ratios could cause the algae present to shift from the more desirable green algae to the less desirable blue-green algae. Low alkalinity waters may tend to support excessive populations of blue-green algae to a greater extend than high alkalinity waters with the same nitrogen and phosphorous input (James and Lee 1974). This shift to blue-green algae would cause a greater deterioration of the water quality than a corresponding number of green algae, diatoms and other forms (ibid).

So, the greatest value of an analysis of the $C: N$ ratios is the insight that it gives into the impact of sewage treatment plant effluents on a soft water river: 1) to create a situation of possible carbon limitation downstream and 2) to shift the algal species downstream to the less desirable blue-green algae. This is indeed what has happened in the Tualatin River.

This discussion also supports the hypothesis that the river below Rock Creek is fulfiling the role of a sewage 
treatment lagoon during the summer.

\section{BIOLOGICAL PARAMETERS}

Diversity and Biological Indicators of Water Quality

Diversity $\left(H^{\prime}\right)$ as measured by the Shannon-Weaver Index, $H^{\prime}=-\Sigma p_{i} \log p_{i}$ where $p_{i}=n_{i} / N$, takes into account the number of species in a population and the evenness of distribution of the total population among the species (Pielou 1969; Poole 1974). This index, which is independent of sample size, is taken from information theory and predicts the average uncertainty per individual in a random sample (Poole 1974).

One way to assess the impart of the human use of a river is to determine any changes in the diversity of the organisms along the stream length as measured by the ShannonWeaver Index. When applied to an aquatic system, diversity is generally expected to decrease following any recognizable alteration of an ecosystem and therefore, should be a good biological indicator for most forms of pollution (Cole 1973). Wilhm and Dorris (1968) consider the diversity index to be one of the best ways to evaluate water pollution. Maximum diversity occurs when all individuals in a population belong to a different species. In polluted water a few species have many individuals.

Diversity values for the net plankton at each station (except Rock Creek) were calculated for eight sampling 
periods (Table VI).

A two-way analysis of variance (Appendix A) showed that despite one very low diversity value (Rood Road, August 1972) there was no significant difference in the diversities with downstream flow or from season to season. Thus, at least for this middle course of the river consumptive use of the water and the organic enrichments discharged into the river did not affect the diversity of the organisms in the net plankton. The species of organisms and the total population numbers ( $T a b l e ~ V I I)$ may have changed but the diversity did not.

Margalef (1969) states that when diversity ( $H^{\prime}$ ) is measured in bits/individual $\left(\log _{2}\right)$ it reaches its upper limit around 5. He found that in oligotrophic water $\mathrm{H}^{\prime}$ approaches 5, whereas in an eutrophic area $H^{\prime}$ averages 2. By this scale the middle course of the Tualatin River (average $H^{\prime}=$ 3.1) is eutrophic. By using the scale described by Wilhm and Dorris (1968), the diversity values for the same section of the Tualatin River indicate that it is not heavily polluțed.

Another way. to assess the impact of human use of a river is to relate the genera and species of organisms present to their trophic status or to the saprobic system. McHugh (1972) has found that $85 \%$ of the water within the state of Oregon is B-mesosaprobic, including the Tualatin River. Of the approximately 30 species McHugn defines as 
SHANNON-WEAVER DIVERSITY INDEX TUALATIN RIVER SAMPLING STATIONS AUGUST 1972 TO AUGUST 1973

$$
H^{\prime}=-\sum_{i=1}^{n} p_{i} \log _{2} p_{i}
$$

$\begin{array}{ccccccc}\text { Date } & \text { Gaston } & \text { Dilley } & \text { Cornelius } & \text { Hillsboro } & \text { Rood } & \text { Farmington } \\ \text { Aug. } 72 & 3.6 & 2.8 & 3.1 & 3.3 & 0.6 & 3.4 \\ \text { Oct. } 72 & 2.9 & 2.6 & 3.2 & 3.5 & 3.8 & 3.4 \\ \text { Dec. } 72 & (2.9) & 2.9 & (3.1) & 3.2 & (3.4) & 3.5 \\ \text { Mar. } 73 & 2.1 & 3.1 & 3.1 & 3.2 & 3.4 & 3.3 \\ \text { May } 73 & 3.3 & 3.5 & 2.8 & 3.6 & 3.3 & 3.6 \\ \text { Jun. } 73 & 2.3 & 3.1 & 3.5 & 3.1 & 3.3 & 3.2 \\ \text { Jul. } 73 & 3.4 & 3.0 & 3.6 & 2.8 & 3.2 & <2.8 \\ \text { Aug. } 73 & 3.2 & 2.9 & 3.8 & 3.8 & 2.9 & 2.9\end{array}$

Note: Data in parentheses were calculated by a least squares equation (floods made sampling dangerous at this time). 
TABLE VII

ESTIMATES OF THE POPULATION

OF THE NET PLANKTON IN THE TUALATIN RIVER

(number per liter)

\begin{tabular}{|c|c|c|c|c|c|c|c|}
\hline \multicolumn{2}{|c|}{ Date } & \multirow{2}{*}{$\begin{array}{c}\text { Gaston } \\
305\end{array}$} & \multirow{2}{*}{$\begin{array}{c}\text { Dilley } \\
1348\end{array}$} & \multirow{2}{*}{$\begin{array}{c}\text { Cornelius } \\
138\end{array}$} & \multirow{2}{*}{$\begin{array}{c}\text { Hillsboro } \\
1162\end{array}$} & \multirow{2}{*}{$\begin{array}{l}\text { Rood } \\
1863\end{array}$} & \multirow{2}{*}{$\begin{array}{c}\text { Fanmington } \\
596\end{array}$} \\
\hline Aug. & 72 & & & & & & \\
\hline oct. & 72 & 1303 & 669 & 589 & 199 & 310 & 297 \\
\hline Dec. & 72 & --- & 123 & --- & 874 & --- & 118 \\
\hline Mar. & 73 & 999 & 563 & 574 & 705 & 200 & 476 \\
\hline May & 73 & 753 & 885 & 965 & 2059 & 733 & 900 \\
\hline Jun. & 73 & 212 . & 3111 & 1767 & 1540 & 1781 & 2002 \\
\hline Jul. & 73 & 555 & 3211 & 687 & 1160 & 2499 & 8258 \\
\hline Aug. & 73 & 336 & 1252 & 739 & 1832 & 8813 & 2132 \\
\hline
\end{tabular}

Note: Count is in number of cells or colonies per liter as determined by the Membrane Filter Method (APHA 1971). 
being indicators (without qualification) of B-mesosaphrobic water quality, one-half were present in the net plankton of the Tualatin River (Appendix B). McHugh also states that the blue-green algal blooms in the summer in the river indicate that the water contains much organic matter, even though the organic matter is not necessary for the growth of the blue-green algae.

From Palmer's list (1969) of the algal genera which are tolerant of organic pollution, 51 out of 60 were present in the Tualatin River. Brooks (1970) states that it is possible that Bosmina longirostris (a zooplankter) is a product of an enriched aquatic ecosystem. This cladoceran is the only dominant one in the middle course of the river.

Table VIII shows the dominant net plankton at each station for various times of the year. The percent of the total population for each genus in the sample is also given. These figures were obtained from the data necessary to determine the diversity at each station for each time period. The upstream stations, Gaston and Dilley, have only benthic forms as dominants in the net plankton all year around. If a bloom should. form it is usually of Melosira varians and Cymbelza tumida or $c$. ventrosica. Cornelius Station has planktonic blue-green algae in the fall and spring, but has planktonic Melosira granulata, M. italica, and M. distans in July as the dominants. From late spring and throughout the summer Hillsboro Station has mostly planktonic species 
TABLE VIII

DOMINANT GENERA IN THE NET PLANKTON AT SELECTED STATIONS ON THE

\begin{tabular}{|c|c|c|c|c|c|c|c|c|c|c|c|c|c|c|c|}
\hline STATION & & GUST 1972 & & TOBER 1972 & & CEMBER 1972 & & $\mathrm{RCH} 1973$ & MAY & 1973 & JUNE' & 1973 & July 1973 & Augu & ust 1973 \\
\hline & 8 & Genus & 8 & Genus & $\$$ & Genus & 8 & Genus & 86 & Benus & 8 & Genus & Genus & $8 c$ & Gerius \\
\hline Gaston & $\begin{array}{l}35 \\
23 \\
10\end{array}$ & $\begin{array}{l}\text { Syndra } \\
\text { Mavicula } \\
\text { Nitzschia }\end{array}$ & $\begin{array}{l}33 \\
16 \\
13 \\
11\end{array}$ & $\begin{array}{l}\text { Melosira } \\
\text { Cymbella } \\
\text { Synedra } \\
\text { Gomphonema }\end{array}$ & & ND & $\begin{array}{r}54 \\
26 \\
5\end{array}$ & $\begin{array}{l}\text { Helosira } \\
\text { Navicula } \\
\text { Synedra }\end{array}$ & $\begin{array}{l}17 \\
16 \\
14\end{array}$ & $\begin{array}{l}\text { Gomphonema } \\
\text { Cymbella } \\
\text { Navicula }\end{array}$ & $\begin{array}{l}57 \\
14 \\
12\end{array}$ & $\begin{array}{l}\text { Cymbella } \\
\text { Navicula } \\
\text { Synedra }\end{array}$ & $\begin{array}{l}40 \text { Cymbelia } \\
24 \text { Melosira } \\
13 \text { Navicula } \\
13 \text { Nitzschia }\end{array}$ & $\begin{array}{l}36 \\
14 \\
12 \\
12\end{array}$ & $\begin{array}{l}\text { Cymbella } \\
\text { Synedra } \\
\text { Mougeotia } \\
\text { Navicula }\end{array}$ \\
\hline Dilley & $\begin{array}{l}34 \\
19 \\
16 \\
12\end{array}$ & $\begin{array}{l}\text { Navicula } \\
\text { Synedra } \\
\text { Melosira } \\
\text { Nitzschia }\end{array}$ & $\begin{array}{l}38 \\
24 \\
12 \\
11\end{array}$ & $\begin{array}{l}\text { Cymbella } \\
\text { Navicula } \\
\text { Synedra } \\
\text { Melosira }\end{array}$ & $\begin{array}{l}26 \\
19 \\
13\end{array}$ & $\begin{array}{l}\text { Synedra } \\
\text { Melosira } \\
\text { Pinnularia }\end{array}$ & $\begin{array}{r}29 \\
20 \\
9 \\
9\end{array}$ & $\begin{array}{l}\text { Navicula } \\
\text { Helosira } \\
\text { Gomphonema } \\
\text { Diatoma }\end{array}$ & $\begin{array}{l}23 \\
21 \\
16 \\
16\end{array}$ & $\begin{array}{l}\text { Synedra } \\
\text { Navicula } \\
\text { Cymbeila } \\
\text { Melosira }\end{array}$ & $\begin{array}{r}51 \\
15 \\
15 \\
5\end{array}$ & $\begin{array}{l}\text { Cymbella } \\
\text { Melosira } \\
\text { Synedra } \\
\text { Navicula }\end{array}$ & $\begin{array}{l}37 \text { Nitzschia } \\
35 \text { Melosira } \\
26 \text { Cymbella } \\
18 \text { Navicula }\end{array}$ & $\begin{array}{l}43 \\
23 \\
13\end{array}$ & $\begin{array}{l}\text { Cymbella } \\
\text { Navicula } \\
\text { Synedra }\end{array}$ \\
\hline Cornelius & $\begin{array}{l}43 \\
14 \\
11\end{array}$ & $\begin{array}{l}\text { Melosira } \\
\text { Synedra } \\
\text { idavicula }\end{array}$ & $\begin{array}{l}36 \\
12 \\
10\end{array}$ & $\begin{array}{l}\text { \#Oscillatoria } \\
\text { Microcystis } \\
\text { Navicula }\end{array}$ & & ND & $\begin{array}{l}42 \\
14\end{array}$ & $\begin{array}{l}\text { Navicula } \\
\text { Gomphonema }\end{array}$ & $\begin{array}{l}49 \\
16\end{array}$ & $\begin{array}{l}\text { toscillatoria } \\
\text { Navicula }\end{array}$ & $\begin{array}{r}31 \\
31 \\
21 \\
7\end{array}$ & $\begin{array}{l}\text { Microcystis } \\
\text { Melosira } \\
\text { tOscillatoria } \\
\text { Scenedesmus }\end{array}$ & $\begin{array}{l}37 \text { Melosira } \\
13 \text { Nitzschia } \\
8 \text { Navicula } \\
6 \text { Cymbella }\end{array}$ & $\begin{array}{l}21 \\
21 \\
16\end{array}$ & $\begin{array}{l}\text { Melosira } \\
\text { Mavicula } \\
\text { Synedra }\end{array}$ \\
\hline Hillsboro & $\begin{array}{r}42 \\
18 \\
4\end{array}$ & $\begin{array}{l}\text { Melosira } \\
\text { llavicuía } \\
\text { Stephanodiscus }\end{array}$ & $\begin{array}{r}35 \\
15 \\
\text { s11 } \\
8\end{array}$ & $\begin{array}{l}\text { Havicula } \\
\text { Melosira } \\
\text { Hitzschia } \\
\text { Gyrosigma }\end{array}$ & $\begin{array}{l}19 \\
14 \\
14\end{array}$ & $\begin{array}{l}\text { Melosira } \\
\text { Navicula } \\
\text { Fragillaria }\end{array}$ & $\begin{array}{r}33 \\
25 \\
9 \\
9\end{array}$ & $\begin{array}{l}\text { Synedra } \\
\text { Navicula } \\
\text { Brachinonus } \\
\text { Diatoma }\end{array}$ & $\begin{array}{l}23 \\
19 \\
16 \\
14\end{array}$ & $\begin{array}{l}\text { Synedra } \\
\text { toscillatoria } \\
\text { lavicula } \\
\text { Melosira }\end{array}$ & $\begin{array}{r}54 \\
8 \\
7\end{array}$ & $\begin{array}{l}\text { Melosira } \\
\text { Microcystis } \\
\text { Scenedesmus }\end{array}$ & $\begin{array}{l}31 \text { Melosira } \\
26 \text { toscillatoria } \\
21 \text { Microcystis } \\
9 \text { Stephanodiscus }\end{array}$ & $\begin{array}{r}31 \\
23 \\
7\end{array}$ & $\begin{array}{l}\text { Melosira } \\
\text { Synedra } \\
\text { Nitzschia }\end{array}$ \\
\hline Rood Road & $\begin{array}{rl}94 & 1 \\
1 & 1 \\
1 & \end{array}$ & $\begin{array}{l}\text { Melosira } \\
\text { Branchionus } \\
\text { Stephanodiscus }\end{array}$ & $\begin{array}{r}26 \\
25 \\
59\end{array}$ & $\begin{array}{l}\text { Navicula } \\
\text { Melosira } \\
\text { Synedra }\end{array}$ & & ND & $\begin{array}{r}14 \\
14 \\
7\end{array}$ & $\begin{array}{l}\text { Navicula } \\
\text { Synedra } \\
\text { Diatoma }\end{array}$ & $\begin{array}{ll}31 & \\
28 & 5 \\
13 & 1 \\
13 & 1\end{array}$ & $\begin{array}{l}\text { BOscillatoria } \\
\text { Synedra } \\
\text { Navicula } \\
\text { Melosira }\end{array}$ & $\begin{array}{r}44 \\
13 \\
9 \\
7\end{array}$ & $\begin{array}{l}\text { Melosira } \\
\text { Microcystis } \\
\text { Scenedesmus } \\
\text { Anabaena }\end{array}$ & $\begin{array}{l}30 \text { Microcystis } \\
21 \text { :Oscillatoria } \\
16 \text { Anabaena } \\
13 \text { Melosira }\end{array}$ & $\begin{array}{r}40 \\
40 \\
4\end{array}$ & $\begin{array}{l}\text { Microcystis } \\
\text { Melosira } \\
\text { Bosmina }\end{array}$ \\
\hline Farmington & $\begin{array}{r}47 \\
22 \\
81\end{array}$ & $\begin{array}{l}\text { Melosira } \\
\text { Microcystis } \\
\text { Pinnularia }\end{array}$ & $\begin{array}{l}21 \\
21 \\
16 \\
10\end{array}$ & $\begin{array}{l}\text { Helosira } \\
\text { Stephanodiscus } \\
\text { Navicular } \\
\text { Nitzschia }\end{array}$ & $\begin{array}{l}33 \\
14 \\
11\end{array}$ & $\begin{array}{l}\text { Synedra } \\
\text { Fragillaria } \\
\text { Navicula }\end{array}$ & $\begin{array}{l}16 \\
15 \\
15 \\
11\end{array}$ & $\begin{array}{l}\text { Synedra } \\
\text { ijitzschia } \\
\text { Branchionus } \\
\text { Navicula }\end{array}$ & $\begin{array}{ll}30 & : \\
14 & 1 \\
14 & 5 \\
10 & \end{array}$ & $\begin{array}{l}\text { NOscillatoria } \\
\text { Navicula } \\
\text { Synedra } \\
\text { Melosira }\end{array}$ & $\begin{array}{r}36 \\
21 \\
8 \\
7 \\
7\end{array}$ & $\begin{array}{l}\text { Melosira } \\
\text { dOscillatoria } \\
\text { Synedra } \\
\text { Microcystis } \\
\text { Navicula }\end{array}$ & $\begin{array}{l}42 \text { Microcystis } \\
17 \text { Melosira } \\
14 \text { Anabaena } \\
6 \text { Brachionus }\end{array}$ & $\begin{array}{r}38 \\
18 \\
16 \\
9\end{array}$ & $\begin{array}{l}\text { Microcystis } \\
\text { Melosira } \\
\text { Bosmina } \\
\text { Pinnularia }\end{array}$ \\
\hline
\end{tabular}


as do Rood Road and Farmington Stations, however, in the winter and early spring, benthic forms are more common. In the fall Hillsboro and Rood Road Stations have more benthic forms, but Farmington Station still has planktonic forms. Summer blooms at Hillsboro, Rood Road, and Farmington Stations are a mixture of blue-green algae and planktonic Mezosira spp.

All the stations have only one or two primary dominant species with up to three secondary ones. The primary dominant may be from one-third to one-half of the total population in the sample. It is for this reason that the diversity indices show the river to be eutrophic according to Margalef's scale (see page 104).

The biological species and the diversity values agree favorably with the eutrophication and enrichment indicated by the chemical data of this study.

Man's use of the middle course of the river has changed the species composition and the quality of the water biologically (shift to blue-green algae, increased biomass) as it flows, but it has not changed the species diversity in the river.

\section{NON-POINT NUTRIENT SOURCES}

Suburban Street Drainage.

Four grab samples were taken from suburban street drainage ditches in the city of Hillsboro (1973, population 
17,000). These ditches were not part of the concrete-lined, combined sanitary and storm sewer system, but were soil ditches that drained residential and arterial streets into small gullies. None of these ditches drained directly into the river.

Table IX gives the values of the analyzed parameters. There were no run-off samples from the summer because there was scant rainfall.

The results indicate that water from street run-off could contribute nutrients to the Tualatin River. However, the sampling was too limited to provide an estimate of the quantitative significance of the amount of nutrients reaching the river.

Precipitation.

On 7 and 12 December 1972 during a snowfall two samples of snow were melted in a clean pyrex beaker and analyzed for nutrient content. The December 7 sample was from snow that had been on the ground for three or four days, the December 12 sample was from freshly fallen snow. In both cases the first few centimeters were brushed aside by hand before the snow was collected. One liter of the snow water was preserved for trace element analysis.

On 15 January 1973 a sample of rain was collected on a large household plastic bag laid out on an elevated hard surface. This sample was analyzed for its nutrient content, but 
TABLE IX

\section{NUTRIENT CONTRIBUTIONS IN} STREET DRAINAGE DITCHES

\begin{tabular}{|c|c|c|c|c|c|c|c|c|c|}
\hline STATION ${ }^{a}$ & DATE & TIME & $\mathrm{pH}$ & $\begin{array}{l}\mathrm{NH}_{4}-\mathrm{N} \\
\mathrm{mg} / \mathrm{I}\end{array}$ & $\begin{array}{l}\mathrm{NO}_{3}-\mathrm{N} \\
\mathrm{mg} / \mathrm{I}\end{array}$ & $\begin{array}{l}\mathrm{PO}_{4} \\
\mathrm{mg} / \mathrm{I}\end{array}$ & $\begin{array}{l}\mathrm{ALK}_{\mathrm{t}} \\
\mathrm{ng} / \mathrm{I} \\
\mathrm{CaCO}_{3}\end{array}$ & $\begin{array}{l}{ }^{\mathrm{T}} \\
{ }^{\circ} \mathrm{C}\end{array}$ & $\begin{array}{l}\text { TURB } \\
\text { JTU }\end{array}$ \\
\hline$\times 008$ & $1 / 16 / 73$ & 2000 & 6.4 & 0.70 & 0.97 & 0.50 & 45 & 9 & 60 \\
\hline$x 008$ & $2 / 25 / 73$ & 1630 & 7.0 & 1.00 & 0.45 & 4.50 & 52 & 10 & $-\cdots$ \\
\hline$x 008$ & $5 / 24 / 73$ & 1930 & -- & 1.15 & 0.28 & 4.41 & 98 & 13 & 25 \\
\hline $\mathrm{x} 010$ & $5 / 24 / 73$ & 1940 & -- & 1.50 & 0.50 & 4.08 & 91 & 13 & 100 \\
\hline
\end{tabular}

a: see Table XII 
none was sayed for further analysis.

The results of the tests on the precipitation samples is given in Table $x$.

The $\mathrm{pH}$ of the precipitation compares with the study by Klein (1974) on the acidity of the precipitation in the United States. The $\mathrm{pH}$ of the snow definitely affected the Tualatin River flood of December 1972 (see section on $\mathrm{pH}$ ).

The nutrient content of the precipitation is typical (Chapin and Uttomark 1973).

These few samples indicate that precipitation contributes to the nutrient loading of the Tualatin River ecosystem.

Farm Ditch Run-off.

Twelve water samples were taken from various farm ditches between Hillsboro and Cornelius. All samples were taken from flowing water, Table XI gives the concentrations of the parameters analyzed.

In those ditches sampled in December and again in February, there was an increase in the concentrations of the inorganic nitrogen species and the concentration of polyphosphate. Since the croplands had become saturated from rainfall, the changes in concentrations in the run-off indicate a potential nutrient supply to the river.

The farm ditch ( $\mathrm{X} 012$ ) that entered the river at Cornelius Station was sampled twice. In February the inorganic nitrogen in the ditch and in the niver were about the same, 


\section{TABLE $X$}

\section{NUTRIENT CONTRIBUTIONS}

IN PRECIPITATION

$\begin{array}{ccccccc}\text { DATE } & \begin{array}{c}\mathrm{T} \\ { }^{\circ}\end{array} & \begin{array}{c}\mathrm{NH}_{4}-\mathrm{N} \\ \mathrm{mg} / 1\end{array} & \begin{array}{c}\mathrm{NO}_{3}-\mathrm{N} \\ \mathrm{mg} / 1\end{array} & \begin{array}{l}\mathrm{PO}_{4} \\ \mathrm{mg} / 1\end{array} & \begin{array}{c}\mathrm{ALK}_{\mathrm{t}} \\ \mathrm{mg} / \mathrm{I} \\ \mathrm{CaCO}\end{array} & \mathrm{pH} \\ 12 / 07 / 72 & 0 & 0.45 & 0.33 & 0.22 & 0 & 4.5 \\ 12 / 12 / 72 & 0 & 0.30 & 0.25 & 0.11 & 0 & 4.5 \\ 1 / 15 / 73 & 9 & -1 & 0.06 & 0.09 & 1 & 5.1\end{array}$


TABLE XI

\section{CONCENTRATIONS OF NUTRIENTS IN SELECTED FARM DRAINAGE DITCHES \\ TUALATIN RIVER BASIN}

\begin{tabular}{|c|c|c|c|c|c|c|c|c|}
\hline STATION & DATE & TIME & $\mathrm{pH}$ & $\begin{array}{l}\mathrm{NH}_{4}-\mathrm{N} \\
\mathrm{mg} / \mathrm{I}\end{array}$ & $\begin{array}{l}\mathrm{NO}_{3}-\mathrm{N} \\
\mathrm{mg} / \mathrm{I}\end{array}$ & $\begin{array}{l}\mathrm{PO}_{4} \\
\mathrm{mg} / \mathrm{I}\end{array}$ & $\begin{array}{l}\mathrm{ALK}_{\mathrm{t}} \\
\mathrm{mg} / \mathrm{I} \\
\mathrm{CaCO}\end{array}$ & ${ }^{\mathrm{T}}$ \\
\hline$x 002$ & $12 / 02 / 72$ & 1200 & 6.8 & 0.50 & 0.25 & 3.00 & 48 & 9 \\
\hline$x 003$ & $12 / 02 / 72$ & 1110 & 7.5 & 0.65 & 0.10 & 2.60 & 82 & 8 \\
\hline $\mathrm{X} 004$ & $12 / 02 / 72$ & 1100 & 7.3 & 0.75 & 0.11 & 0.95 & 119 & 8 \\
\hline X005 & $12 / 02 / 72$ & 1030 & 7.8 & 0.50 & 0.23 & 4.00 & 249 & 9 \\
\hline $\mathrm{X003}$ & $02 / 25 / 73$ & 1605 & 7.2 & 1.25 & 3.80 & 4.38 & 38 & 10 \\
\hline X004 & $02 / 25 / 73$ & 1555 & 7.3 & 1.00 & 3.60 & 4.25 & 54 & 10 \\
\hline $\mathrm{X} 012$ & $02 / 25 / 73$ & 1530 & 7.7 & 0.80 & 0.53 & 4.00 & 113 & 10 \\
\hline $\mathrm{X} 002$ & $02 / 25 / 73$ & 1510 & 6.9 & 1.32 & 2.75 & 4.75 & $3 I$ & 10 \\
\hline $\mathrm{X} 011$ & $06 / 14 / 73$ & 1700 & 7.9 & 0.50 & 0.60 & 4.80 & 129 & 11 \\
\hline $\mathrm{X} 011$ & $06 / 17 / 73$ & 0500 & 7.1 & 0.40 & 0.70 & 5.20 & 146 & 11 \\
\hline $\mathrm{X} 012$ & $07 / 21 / 73$ & 1435 & $*$ & 0.33 & 0.33 & 3.90 & 69 & 21 \\
\hline
\end{tabular}

a: see Table XII 
TABLE XII

\section{LOCATION OF NON-POINT SOURCE}

SAMPLING SITES

\begin{tabular}{|c|c|}
\hline CODE & LOCATION \\
\hline $\mathrm{x} 002$ & Burkhalter Road (farm ditch) \\
\hline $\mathrm{X} 003$ & Golf Course Road (farm ditch) \\
\hline $\mathrm{X} 004$ & $\begin{array}{l}\text { Cornelius, east of Golf Course Road } \\
\text { (farm ditch) }\end{array}$ \\
\hline $\mathrm{x} 005$ & LaFollett Road (farm ditch) \\
\hline$\times 007$ & $\begin{array}{l}\text { Hillsboro, Cornell Road (street } \\
\text { ditch) }\end{array}$ \\
\hline $\mathrm{x} 009$ & $\begin{array}{c}\text { Cornelius, Golf Course Road at } \\
\text { Golf Course (farm ditch) }\end{array}$ \\
\hline $\mathrm{x} 010$ & $\begin{array}{l}\text { Hillsbóno, McKinney School (street } \\
\text { ditch) }\end{array}$ \\
\hline $\mathrm{x} 01$ & McKay Creek, (farm ditch) \\
\hline $\mathrm{x} 012$ & Connelius Station (farm ditch) \\
\hline
\end{tabular}


but in July the inorganic nitrogen in the ditch was 4 to 5 times greater than in the river upstream. In July this ditch had return water from irrigation, thus, the indication is that if there were return water from summer irrigation it could add nutrients to the river.

Ordinarily the farm drainage ditches in the Tualatin Valley do not have water in them from May or June to October, so summer samples were usually not obtainable. Farm Ditch X01l sampled twice in June 1973 ran all summer. This is the ditch that was sampled for trace elements. About four weeks before the water samples were taken, the fields adjoining this ditch were fertilized with 16-20-0 fertilizer $(16 \% \mathrm{~N}, 20 \% \mathrm{P}, 0 \% \mathrm{~K})$ at the rate of $695 \mathrm{~kg} / \mathrm{ha}(620 \mathrm{lb} / \mathrm{acre})$. The fields drained by this ditch are regularly irrigated until midsummer. The ditch drains into a farm pond from which the water for irrigation is pumped (i.e. its recycled). Both times Farm Ditch $X 011$ was sampled the ortho-phosphate values were the same $(1.20 \mathrm{mg} / \mathrm{l})$. There was an increase in the poly-phosphates, but no change in the sum of the inorganic nitrogen species. The ammonium-nitrogen values were similar to the river at Hillsboro Station (the nearest one), but the nitrate-nitrogen was 3.5 times greater and the poly-phosphates were 1.8 times the concentration in the river.

Inorganic nitrogen and to a lesser extend poly-phosphates could enter the river from farm run-off in the 
summers, when biological activity in the river is the greatest. If farm run-off were to enter the river above Hillsboro where there is a possibility of nitrogen limitation, the algal blooms could be stimulated further upstream. In general, however, sprinkler irrigation does not produce return flow.

Thus, it is evident that suburban street drainage, precipitation, and farm run-off could contribute nitrogen and phosphorous to the river. A more extensive sampling program would be required to evaluate their quantitative significance. 


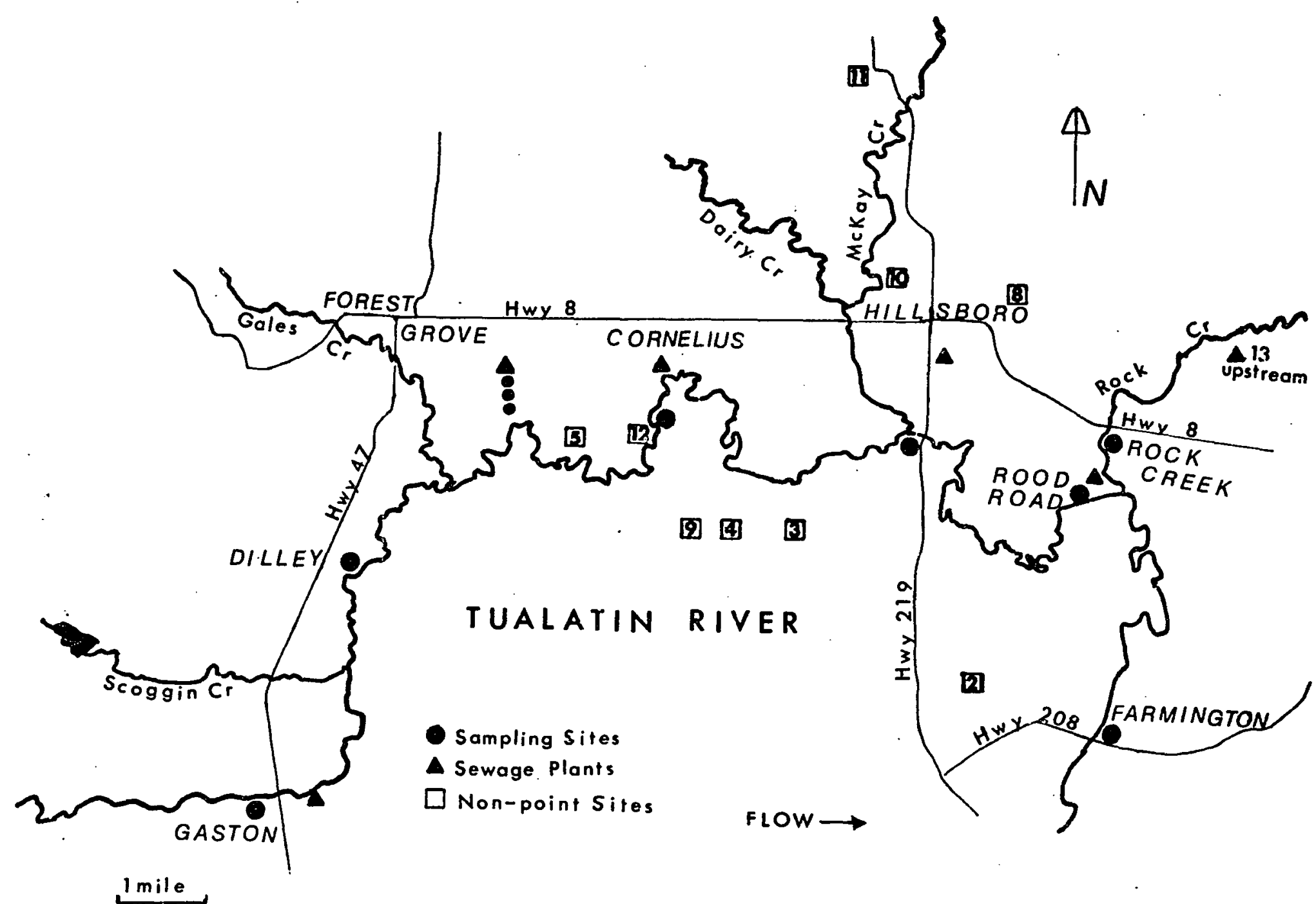

Figure 30. Sampling stations, sewage treatment plants, and tributaries along the middle course of the Tualatin River. This map clarifies the locations along the river for the discussion on stream management. 


\section{CHAPTER VI \\ CONCLUSIONS}

\section{A DISCUSSION RELATING TO THE DEVELOPMENT OF THE}

MANAGEMENT OF WATER IN THE TUALATIN -BASIN

Use of water in the Tualatin River Basin has caused some environmental problems to become more acute as the population of the valley increases.

Water supply.

Lack of water in the river as well as water for municipalities and agriculture has been one of the major problems. The construction of Scoggin Dam and its resultant reservoir will partially alleviate this water dirth.

Releases of stored water from the Scoggin Reservoir, beginning in 1975, will give additional flow to the Tualatin River, so that periods of zero flow may no longer exist. It is difficult to estimate what the sustained minimum flow will be through the middle course of the river. The oregon Iron and Steel Company at Lake Oswego on the lower river will begin to enforce its prior water right for $1.6 \mathrm{~m}^{3} / \mathrm{s}(57.5$ cfs) from the natural flow of the Tualatin River. An additional $0.6 \mathrm{~m}^{3} / \mathrm{s}$ ( $20 \mathrm{cfs}$ ) is to be maintained for aquatic life below the Lake Oswego diversion canal, making a total of $2.2 \mathrm{~m}^{3} / \mathrm{s}(80 \mathrm{afs})$. Water purchased for irrigation by farmers in the middle and lower reaches of the river will 
also increase the flow in the middle course of the stream. Therefore, there should be a substantial increase in flow between Scoggin Creek and Farmington during the summer, especially since the amount withdrawn from the river is to be carefully monitored so that only entitled users receive their allotted water.

What effect this increased flow will have on the width of the channel, depth of the water, amount of sediment transport, amount of sediment scour, streambed gradient, meander of the river, temperature of the water, concentrations of the various chemicals, and changes in the algae composition and biomass and other aquatic life in the river is unknown. (There was no environmental impact statement requirsd for the Scoggin Project). Even if some of the effects are predicatable; the total effect on the whole river system is unpredictable.

Other water storage facilities are being contemplated on the Upper Tualatin above Gaston, on McKay Creek, and on Rock Creek. The potential environmental impact of more impoundments and releases of stored water from these reservoirs must be critically studied.

Water Quality.

The primary purpose of these water storage facilities is for irrigation, and municipal and industrial water supplies. Scoggin Reservoir is allocated: $68 \%$ for irrigation, 
$23 \%$ for muncipal and industrial supplies; and $12 \%$ for water quality control with some overlapping use.

Whether the increased use of irrigation water will

allow nutrients to be leached or washed into the river, will depend on the amount of run-off. If sprinkler irrigation is conservatively managed, as it has been, the return of water to the river system may be minimal and agriculture will not supply additional nutrients to the river ecosystem. However, if irrigation practices are changed so that water is returned to the river after being used (The US Bureau of Reclamation (1963) estimates that $28 \%$ of the alloted irrigation water will be returned for other project uses.), the return water may create a nutrient source which might have an impact on the aquatic ecosystem. This would be pertinent if inorganic nitrogen is supplied to areas of the river where that nutrient is now a possible limiting factor for algal growth.

Municipal and industrial water lise implies the utilization of water low in nutrients and the return of water as sewage and industrial waste that is high in nutrients. This is especially true in the Tualatin Valley, since there are many canneries which contribute to the industrial waste load in the critical, summer period.

One thing is forecast, the total water required for water quality control cannot be met by releases from Scoggin Reservoir (USBR 1963). The flow augmentation from Scoggin 
Reservoir alone cannot possibly dilute Rock Creek's contributions of ammonium-nitrogen and poly-phosphates to concentrations that would not stimulate algal production in the Tualatin. The maximum ammonium-nitrogen was about $12 \mathrm{mg} / \mathrm{l}$; $0.3 \mathrm{mg} / \mathrm{l}$ will stimulate algal blooms. The maximum phosphate was $19 \mathrm{mg} / \mathrm{l} ; 0.05 \mathrm{mg} / \mathrm{l}$ will stimulate algal blooms if there is no other factor limiting. growth. (Mackenthum 1965 and Sawyer 1947).

Effluents from four of the present sewage treatment plants in the Rock Creek basin are to be diverted to the 0.87 $\mathrm{m}^{3} / \mathrm{s}$ (20 mgd)(DEQ 1974b) plant now being constructed at Durham at the mouth of Fanno Creek in the lower Tualatin. One of these plants is the one operated by Tektronix, which will transfer the trace elements from that source to the lower river. Tektronix now has a discharge permit for 2.0 mg/ I heavy metals (DEQ 1974b).

The Hillsboro-Rock Creek plant, below the Rock Creek sampling station for this study, will be expanded to 0.13 $\mathrm{m}^{3} / \mathrm{s}(3.0 \mathrm{mgd})$ by 1977 and to $0.53 \mathrm{~m}^{3} / \mathrm{s}(12.0 \mathrm{mgd})$ by 1983 from its present $0.05 \mathrm{~m}^{3} / \mathrm{s}(1.25 \mathrm{mgd})$ and will process sewage from five of the facilities in the Rock Creek basin which will be discontinued. Thus, it is probable that the nutrient loading from sewage treatment plants to the river from Rock Creek will increase.

Not only will there be sewage effluents from treatment plants along Rock Creek, but other sewage treatment plants 
along the mainstem Tualatin are to be enlarged. Some of them have a restriction on dry weather discharge and thus, cannot discharge effluents into the river between June $I$ and November 1.

The Gaston sewage treatment plant $\left(0.005 \mathrm{~m}^{3} / \mathrm{s}, 0.125\right.$ mgd) is to go to dry weather, land irrigation for disposal of effluents by 1976 (DEQ 1974b).

The Forest Grove sewage treatment plant, presently designed for $0.11 \mathrm{~m}^{3} / \mathrm{s}(2.5 \mathrm{mgd})$, is expanding to $0.22 \mathrm{~m}^{3} / \mathrm{s}$ and will include wastes from Cornelius. Forest Grove now uses land irrigation in dry weather, but the DEQ (1974b) may allow the discharge of treated wastes into the river in the river in the near future. This plant will retain its three, large, oxidation ponds which further process secondary effluents before they are discharged into the river.

If dry weather discharge is permitted at Forest Grove, the river downstream from River Mile 55.2 will then have a significant nutrient load that heretofore has not been present during low flow. Since nitrogen may have been limiting to excessive algal growth above Rock Creek, nutrients in the effluents from the Forest Grove plant will probably alter the species and the amount of algae downstream, even with the augmented flow from Scoggin Reservoir. The present restriction against discharge of sewage effluents into the river during dry weather should be continued after the Forest Grove plant has been expanded. 
The Hillsboro-Westside plant (below the Hillsboro sampling station of this study) is to be maintained as is with continued land disposal during dry weather.

Water Use Conflict.

It is ironical that the water from Scoggin Reservoir, by supposedly alleviating a water shortage, which previously curtailed urbanization, may create further water shortages by giving the illusion that plenty of water will be available for increased urbanization. The comprehensive plans of Hillsboro, Washington County, and Columbia Region Association of Governments (CRAG) all foresee increased urbanization for the Tualatin Basin.

Whereas before irrigation was needed to assure and increase agricultural production, which has been the Tualatin Basin's chief economic base, now it is needed even more just to keep the same farm production levels. The amount of land taken out of food production by urbanization has meant that increased yields will be necessary on the remaining farm land to maintain the total production realized before the irrigation project. This is important if agriculture is to remain the basin's chief economical base, and to provide food for the increased populations. In essence, this is more a political than a scientific issue, but the decisions made concerning the use of land and water in the Tualatin Basin will affect the water quantity and quality in the 
river. While the prime justification for building the Scoggin Dam was irrigation, the majority of the population now lives in urban areas.

Trask Reservoir.

In the sumner of 1973 local governmental units published in local newspapers stories of the effect of flow. augmentation from the Trask Reservoir, a small drinking water reservoir in the headwaters of the Tualatin River. They stated that releases of water from the reservoin increased the flow of the river at Farmington (Hizlsboro Argus, 28 August 1973). The flow data from this study conflict with the newspaper story. Neither in 1972 nor in 1973 was there sufficient water released $\left(0.35 \mathrm{~m}^{3} / \mathrm{s}, 8 \mathrm{mgd}\right)$ during the low flow periods of July or August to significantly affect the river below Cornelius, usually extra flow was noted only at Gaston and Dilley. The agricultural drawdown for irrigation was great enough above Cornelius to deplete any water released from the Trask Reservoir. During 1973 the statements in the local press were especially invalid, because there was no flow in the Tualatin from the mouth of Dairy Creek to the mouth of Rock Creek (Figures 8, 11, 13). Trask Reservoir water could not have gotten to Farmington under these conditions as was claimed. 


\section{Waterfowl.}

Floodlands in the Tualatin River basin are a major feeding and resting area for waterfowl. The Tualatin Valley is on the Pacific Flyway as an extension of the Willamette River Basin branch of this flyway.

The US Fish and Wildlife Service (letter by Charles Simmons of US Fish and Wildlife Service to US Bureau of Reclamation 1973) lists the most desirable waterfowl areas in the Tualatin Valley: $6.1 \mathrm{~km}^{2}(1,500 \mathrm{ac})$ at Wapato Lake near Gaston, $5.3 \mathrm{~km}^{2}(1300 \mathrm{ac})$ downstream from Gaston including the confluence of Scoggin Creek and the Tualatin River, $2.8 \mathrm{~km}^{2}(700 \mathrm{ac})$ at the confluence of Gales Creek and the Tualatin, and $5.3 \mathrm{~km}^{2}(1300 \mathrm{ac})$ at Jackson Bottom near Hillsboro (the Hillsboro sampling station of this study). Other areas downstream from Farmington are also listed. In addition, there are large farm ponds, snaller flooded areas along the tributaries, and the sewage oxidation lagoons at Forest Grove which provide resting and feeding areas for both migrating and winter resident birds. When filled, the Scoggin Reservoir will provide a resting, but not feeding, area.

It is difficult to estimate the number of waterfow that use the Tualatin Basin. The Oregon Wildlife Commission (1974, pers. comm.) estimates that over 50,000 winter resident ducks, geese, and swans use the floodplairs as winter 
feeding, grounds. These waterfowl spend the daylight hours on Sauvies Island at the mouth 0 : the Willamette River where there is a bird refuge. They fly into the Tualatin Valley at night, returning to Sauvies Island at dawn. Not included in these approximately 50,000 winter residents are the large number of migrating waterfowl that rest and feed in the area as they move south. No definite estimate was obtainable on the number of migrants. The Oregon Wildlife Commission (Gene Herb 1975 pers. comm.) states that from November to February the average daily count on Sauvies Island was about 70,000 birds with peak counts of 150,000 birds per day. The turnover rate of these birds is unknown.

The Oregon Wildlife Commission also stated that winter resident waterfowl in the Willamette Basin itself will fly north into the Tualatin Basin during flood periods to feed, and determining the number of these birds is impossible.

The US Fish and Wildlife Service (letter of Charles Simmons to US Bureau of Reclamation) in a statewide waterfowl count conducted during the period 8 to 12 January 1973 found that $14 \%$ of the pintail, $33 \%$ of the canvasback ducks, and $23 \%$ of the whistling swans tallied in the state were observed in Washington County.

Many of these areas where waterfowl feed are not wetlands or swamps. In the summer this land is used for agriculture. The crops from this land are economically valuable to humans and provide the winter feed for waterfowl. Many 
of the farmers have permanent duck blinds or quickly placed ones for which they rent hunting rights during the hunting season ( $\$ 400$ to $\$ 1000$ per pond or flooded area per season). The two uses of the same land do not conflict and each is of economic value to the land owner; at the same time they provide habitat for the waterfowl. Because summer agriculture and winter waterfowl use of the same land seem to be compatible, a waterfowl habitat protection system should be established to allow multiple use of the winter floodlands with compatible summer use. Many of these waterfowl areas are along the river's floodplain where construction of buildings is impossible. Therefore, it is not an economic liability to designate these areas for waterfowl habitat protection.

If a landowner chose to participate in a waterfowl habitat protection area; he should have some monetary gain, such as a tax incentive or payment from the license program. This would help insure his cooperation in providing the proper habitat protection.

The US Army Corps of engineers has declared the Tualatin River navigable to the mouth of Gales Creek and up Dairy Creek to the Verboort Bridge. The members of the general public have the right to use any floodwaters below these areas via boats as long as they do not leave their craft (Michael Ray, attorney-at-law, USACE 1374, pers. comm.). This will create conflict of use with owners who sell 
hunting rights over their lands along the navigable sections of the river.

Wise use of a waterfowl habitat protection system would be of value to both the rural economy and the urban scene and provide for continued waterfowl populations.

Channelization and Meanders.

In 1933 and again in 1953 the US Army Corps of Engineers formulated plans for.clearing and channelizing the Tualatin River to dissipate the flooding faster. Recently there has been renewed interest in these previously rejected projects. One of the components of these plans was to straighten the river by cutting out some of the meanders.

The Tualatin River is a meandering stream. It flows through a floodplain which is about $50 \%$ of the total drainage basin. This floodplain is the result of geological sedimentation and fluvial processes which have occurred since the Eocene, when the basalt that formed the initial basin was extruded and then downwarped.

Meanders will usually appear whenever the river traverses a. gentle slope over fine-grained material that is easily eroded and transported, but has sufficient cohesiveness to provide firm banks (Leopold and Langbein 1966). These conditions are apparent in the floodplain of the Tualatin River. 
Most meanders resemble a sine curve, which is also the curve of minimum total work in bending. Meander curves cause the flowing water to erode the concave banks of the stream and to deposit sediment on the convex banks. Thus throughout geological time, the river, in successive steps, occupies all possible positions on the valley floor creating a broad valley--the floodplain of the river. This sine curve assumed by most meandering rivers tends to minimize total erosion. Below Gaston, the mainstem Tualatin River is not now an eroding stream.

A meander lengthens the downstream reaches of a river. It promotes the concave longitudinal profile (Figure 2, page 5) which minimizes the rork of the whole system and consequently causes a uniformity in the rate of energy expenditure per unit length of channel. This uniform rate of energy expenditure is stated by the theory of minimum variance (Curry 1972).

According to the theory of minimum variance rivers subject to variation in flow at different items are better able to carry their varying discharges and sediment load with a raximum efficiency of use of energy received both spatially and temporally if they flow in meandering channels (Curry 1972).

If a meander is cut off, the slope of the riverbed increases and the energy that would be dissipated along the longer meander is now transferred to the shorter straightened 
channel. Consequences of the meander removal would be an increased gradient of the streambed resulting in an increased velocity of the water, increased erosion, increased transportation of sediment load, and increased scouring during flooding. A meander is an effective way for a river. to reduce the impact of flooding on the floodplain. The overflow of water onto the floodplain is an effective storage reservoir for the water so that it can be efficiently discharged with the minimum damage to the whole river system.

Urbanization covers the ground with hard surfaces impervious to water; roofs of buildings, parking lots, and sidewalks and streets which decrease the infiltration rate of precipitation and increases the speed and intensity of the run-off from rains. This helps to increase flooding intensity and irequency. Local governments may respond to this increased flooding by straightening the river channel to increase the run-off rate or the speed of the discharge. When the meander is reduced, the velocity of the water is increased resulting in even more damage from flooding. The hazard to the floodplain is also intensified. Destroying the meander or increasing the bedslope by digging out the channel is not the solution to flood control.

The urbanization of the eastern part of the Tualatin Basin has become so extensive, that the small drainage basins of the tributaries are flooding with increased intensity. This is due as much to inadequate drainage 
culverts in suburban developments as to increased areas of non-permeable surfaces. In almost all cases, damage is caused by increased flooding along small tributaries and not to flooding along the main river channel. Therefore, channelization of the mainstem Tualatin River will not alleviate the problem areas.

The Tualatin River annually (or semi-annually) floods about $62.7 \mathrm{~km}^{2}(15,500 \mathrm{ac})$. In an effort to keep flood losses to a minimum, Washington County has a floodplain ordinance limiting the uses of the 100 year floodplain to those uses compatible with such flooding. In 1974 the ordinance was updated and reaffirmed, but only in the last few years have building permits been carefully scrutinized when near the 100 year floodplain.

The Federal Flood Diseaster Protection Act of 1973 requires that the floodplain (areas inundated on a statistical average of once every 100 years) be mapped and zoned to prohibit new building, and flood insurance be purchased for existing structures on the floodplain so that the floodplain occupant rather than the general public pays for the flood damage. This has been done in Washington County (essentially the Tualatin River Basin).

Federal Presidential Order \#11296, signed in 1966, prohibits federal financial or planning assistance for any construction activity on a floodplain when it will increase flood loss potential by encouraging adjacent floodplain 
development and create greater downstream flooding. It would seem that this order would also apply to channelization projects.

A possible deterent to encroachment on the Tualatin floodplain would be to hold all developers who alter the hydrological conditions of the river or its tributaries to be financially responsible for losses incurred as a result of their developments. This should apply to both public agencies and private developers. This would also be a stimulant to cause housing developments to be planned with adequate culverts and drainage systems to prevent flooding.

The costs of channelizing would be extremely great, and the harmful side effects are significant. By comparison, the costs of controlling development on the floodplain would be small.

\section{STATION SUMMARIES}

Gaston.

Even during the low flow periods the quality of water at Gaston Station was good. Any human influence upon the river at this station did not affect the water quality perceptively.

\section{Dilley.}

At Dilley Station the stress of the summer drought and the resulting low water was more limiting to productivity 
than any human factor. The increase in BOD during the winter was probably due to the effluents from the forest fiber mill on Scoggin Creek. This mill is not allowed to discharge into the creek in the summer. While there was some apparent effect on the water quality at Dilley because of human use, the natural processes within the river can assimilate this impact.

Cornelius.

Cornelius Station was influenced by human activities, both those of agriculture as well as municipalities. The nutrients, organic matter, and organisms from the Forest Grove sewage lagoons affected the water quality at Cornelius. Agricultural drawdown and the inefficient use of that irrigation water reduced the river's ability to support diverse aquatic life. During the summer months there was a decrease in the number of organisms at Cornelius Station relative to Dilley. However, the large surface to volume ratio that the very shallow water presented kept the water oxygenated and in reasonably. good health for aquatic life.

\section{Hillsboro.}

During the summers Hillsboro Station was enriched over the upstream stations both naturally and culturally (Sewage effluents). The river supports increased productivity with occasional algal blooms and may be termed eutrophic. 
There are no toxicants or pullutants entering the river. Higher BOD values in periods of no-flow were caused by increased organic matter in the water. At the same time the oxygen levels were sufficient to maintain aquatic life. In the summer the water quality and quantity at Hillsboro Station were completely dominated by human uses.

Rood Road.

Even though Rood Road Station is eutrophic during the summers, it is more like the stations upstream than Farmington Station. This would not be true if the city of Hillsboro did not dispose of its effluents from its Westside sewage treatment plant by using dry land irrigation in the summer. The water quality at Rood Road Station in the summer is greatly degraded by lack of flow, high water temperatures, and the increased biomass that the nutrients in the water support. It is at Rood Road that the greatest impact of irrigation drawdown and increased nutrients is felt. The water quality at Rood Road Station is dependent entirely upon the human consumptive uses of the water and the wastes discharged into the river upstream.

Rock Creek.

Elevated BOD values and depressed DO levels between Rood Road and Farmington Stations suggested a large source of organic matter entering the river between them. Rock 
Creek was the most logical source of this organic load. The flow of Rock Creek throughout the summer was effluents from sewage treatment plants in 1973. Rock Creek did not support even the quality of life found in the oxidation lagoons of the Forest Grove treatment plant. There were only a few Euglenoids, diatoms, and nematodes. The water was $100 \%$ dependent upon human domestic and industrial wastes.

Farmington.

At Farmington Station conditions in the summer are like the lower river, where the river ponds and pools. This ponding occurs only rarely above Rood Road Station. At other times Farmington Station is an extension of the middle course of the river.

In the summer the effluents of Rock Creek completely dominated the water quality at Farmington Station. The biological processes in the river cannot assimilate the human wastes, thus the human influence on the water quality of the river completely overwhelmes any natural conditions. Only in the summer when algal blooms occur is the energy of the system derived from autochthonous processes. At all other times Farmington Station, as well as those stations upstream, is dependent upon allochthonous material (organic matter in the form of debris and sewage effluents) generated outside the aquatic ecosystem for its energy. It is highly probable that the algal blooms at Farmington 
Station are also dependent upon allochthonous matter in the form of dissolved organics since the blue-green algae blooms are those species known to absorb and use organic compounds directly from the water.

Farmington Station is certainly culturally eutrophic and it is possible that the ammonium-nitrogen concentrations are high enough to limit fish population.

\section{CONCLUSIONS}

1. The main source of organic matter to the aquatic ecosystem of the Tualatin River was allochthonous in the form of leaves, forest debris, sewage treatment plant effluents, and organic matter carried into the river by precipitation and run-off.

2. Only in the summer during periods of algal blooms at Hillsboro, Rood Road, and Farmington Stations were there autotrophic conditions in the river.

3. The algal blooms that do occur in the river contribute oxygen to support the oxidation of the organic wastes and possible nitrification of ammonia loadings. The increased flow at the end of the irrigation season is enough to move the biomass downstream so that areas of excessive decomposition and deoxygenation are not established above Farmington Station,

4. Diversity of the net plankton as measured by the Shannon-Weaver Index did not change from season to season, 
nor with downstream flow. Species in the net plankton were benthic forms at the upper stations and planktonic forms downstream from Hillsboro, especially in the sumer when the river pooled due to reduced flow. The enriched effluents from Rock Creek did not affect the diversity of organisms downstream, but supported a larger biomass. By comparing the diversity values with other studies it was found that the middle course of the Tualatin River is eutrophic but not heavily polluted.

5. Removal of phosphates from sewage treatment plant effluents would not affect the presence of algal blooms in the river downstream from Hillsboro since ambient polyphosphates levels were high enough within this study area to provide sufficient phosphate for algal growth in the downstream areas of the river.

6. Agricultural irrigation returns were minimal, hence nutrient loadings from this source during low flow periods were not significant.

7. There was evidence that nitrification was converting the high ammonium-nitrogen loadings from Rock Creek to nitrates within the river during the time of low flow; June to September.

8. While agricultural drawdown in the summer reduces the water yolume in the river, it removes the nutrient rich sewage effluents from the river to the land where crops are grown. 
9. Trace metal analyses indicate that iron, potassium, nickel, zinc, lead, copper, cobalt, and chromium concentrations were higher during flooding. Turbidities suggest that these elements are deposited on the floodplain. Higher concentrations of arsenic and zinc were found in the farm area. Melted snow water contained concentrations of zinc, copper, and lead greater than those found in the floods caused by the snow melt.

10. The high amounts of ammonium-nitrogen in the river below the mouth of Rock Creek in the summer were probably an effective barrier to fish life. The concentrations of ammonium-nitrogen may have been enough to be toxic to even the most ammonia tolerant fish.

11. From July to September the river below the mouth of Rock Creek functions essentially as a sewage oxidation lagoon for the effluents that make up the flow of Rock Creek.

12. Winter rains and floods flush accumulated nitrates from the watershed and from the river ecosystem at a time of low biological productivity.

13. When the river is flooded it becomes a major feeding and resting area for up to $33 \%$ of some species of Oregon's migratory and winter resident ducks, geese, and swans.

14. The summer release of water from the Trask Reservoir did not influence the river below Cornelius in critical periods of low flow because the water was pumped out for 
inrigation needs before it got to Cornelius.

15. Mezosira Spp. were the dominant algae, except that Microcystis aeruginosa was a major dominant in the algal blooms at Hillsboro, Rood Road, and Farmington Stations. Bosmina longirostris was the dominant cladoceran, and Branchionus plicatilis was the dominant rotifer (see, the net plankton check list, Appendix B).

\section{RECOMMENDATIONS}

1. The Washington County Floodplain Ordinance which limits any construction on the 100 year Tualatin River floodplain, should be continued and rigidly enforced. Only land uses compatible with winter flooding should be allowed on the 100 year floodplain.

2. While it is acknowledged that water is a limiting factor in land use planning in the Tualatin River Basin, any water management projects within the basin should be initiated only with careful, overall considerations for the total drainage basin. A complete technical report of all the physical, biological, economic and social impacts of a water mariagement project upon the whole watershed should be mandatory.

3. Waterfowl habitat protective areas should be established to provide resting and feeding grounds for winter resident birds and migratory waterfowl in the flooded areas of the river basin. The Tualatin Valley, at flood time, is 
a major waterfowl area in western Oregon. It augments and supports two other areas that are important wintering areas-Sauvies Island and the Lower Willamette River Basin.

4. A complete geological, chemical, and biological study should be made of the ortho- and poly-phosphates in the drainage basin of the Tualatin River. This is economically feasible in light of the increased sewage treatment plant effluents scheduled for the river basin.

5. Serious consideration should be given to limiting the inorganic nitrogen compounds entering the Tualatin River, except during periods of low biological productivity. Eventually all sewage treatment plant effluents in the upper and middle river should have nitrogen removal requirements. If any major nutrient is limiting in the river above Rock Creek it is nitrogen.

6. A study should be made on the feasibility of pumping sewage treatment plant effluents during the periods of dry weather into irrigation (pipe or canal) systems that will be built in connection with various water storage facilities (present and future) to provide summer irrigation water. Two factors should be especially noted in such a study: 1) the possibility of pathogenic viruses which might remain viable on a food product and hence be a health hazard; 2) heavy metals that are part of the effluents should not be allowed to affect either the productivity of crops or become a hazard to human consumption of the crops. The use of 
nutrient laden (nitrogen and phosphorous) sewage effluents for agricultural irrigation should be beneficial to municipalities and agriculture.

7. When irrigation from water stored in the Scoggin Reservoir is initiated, a thorough study should be made of all non-point source discharges in the basin for nutrient loadings to the river. Such a study should evaluate the affect of stored water and increased irrigation on the water quality of the river.

8. In light of the possibility that the river is acting as a sewage oxidation lagoon for organic wastes below the mouth of Rock Creek, a study of the total inorganic carbon and the total organic carbon within the Tualatin River should be made. The better the sewage treatment processes in reducing $B O D$, the greater the input of inorganic nutrients into the aquatic ecosystem, thus increasing the possibility of excessive algal growths. When effluents increase from sewage treatment plants at the Forest Grove-Cornelius and the Hillsboro-Rock Creek complexes, an understanding of the total inorganic carbon and the total organic carbon present might be significant in the management of the water quality of the river and the control of algal blooms in the middle and lower river. 


\section{REFERENCES}

Aleem, M. I. H., and M. Alexander. 1958. Cell free nitrification by Nitrobacter. J. Bact. 76(5):510-514.

Alexander, Martin. 1971. Microbial ecology. John Wiley $\varepsilon$ Sons.

Andleman, Julian B. 1973. Incidence, variability, and controlling factors for trace elements in natural, fresh waters. P. 57-88. In Singer, Philip C. [ed.] Trace metals and metal-organic interactions in natural waters. Ann Arbor Science Publisher Inc.

APHA. 1971. Standard methods for examination of water and wastewater. 13th ed. American Public Health Association.

Beckman, W. J. 1972. Combined carbon oxidation in nitrification. JFWPCA $44(10): 1916-1931$.

Bell, George. (ed.) 197I. Oregon blue book. State of Oregon.

Benoit, Richard J. 1969. Geochemistry of eutrophication. p. 614-630. In Eutrophication: causes, consequences, corrections, proceedings of a symposium. National Academy of Science. Washington, D.C.

Benson, Robert J. 1967. The Tualatin River. Washington County historical Society.

Benson, Robert J. 1973. unpublished notes for washington County Historical Society.

Berrow, M.L. and J. Webber. 1972. Trace elements in sewage sludges. J. Sci. Fd. Agric. 23:93-100.

Bigger, J. W. and R. B. Corey. 1969. Agricultural drainage and eutrophication 404-445. In Eutrophication: causes, consequences, corrections. National Academy of Science.

Bowen, H. J. M. 1966. Trace elements in biochemistry. Academic Press.

Brezonik, Patrick L. 1973. Nitrogen sources and cycling in Natural waters. EPA Ecological Research Series EPA660/3-73-002. US Environmental Protection Agency. 
Brooks, John Langdon. 1970. Eutrophication and changes in the composition of zooplankton. P. 236-255. In Eutrophication; causes, consequences, and correctives. National Academy of Science.

Chapin, John D. and Paul D. Uttormark. 1973. Atmospheric contributions of nitrogen and phosphorous. U. of Wis. Water Research Center Technical Report WIS-WRC 73-2/ U. of Wis.

Clesceri, Nicholas L. 1973. Organic nutrient factors affecting algal growth. EPA Ecological Research Series EPA-660/3-73-003, US Environmental Protection Agency.

Cole, Richard A. 1973. Stream community response to nutrient enrichment. JWPCF $45(9): 1874-1887$.

Curry, Robert R. 1972. Rivers--a geomorphis and chemical overview. p. 9-32 In Oglesby, Ray T., Clarence A. Carlson and James A. McCann (ed.) River ecology and man. Academic Press.

DEQ. 1969. Regulations relating to water quality control in Oregon, sections from Oregon administrative rules, chapter 340, regulations current as of January 1, 1969. Oregon Department of Environmental Quality.

DEQ. 1974a. Regulations relating to water quality control in Oregon, sections from Oregon administrative rules, chapter 340, regulations current as of January 1, 1974. Oregon Department of Environmentaj. Quality.

DEQ. 1974b. Municipal effluents; requirements, inventory, and needs, Willamette River basin water quality report. Oregon Departments of Environmental Quality. (unpublished report).

Devey, D. G. and N. Harkness. 1973. The significance of man-made sources of phosphate detergents and sewage. Water Res. 7:35-54.

Dugan, Patrick R. 1972. Biochemical ecology of water pollution. Plenum Press.

EIFAC. 1973. Report of ammonia and inland fisheries of the European Inland Fish Advisory Committee and Working Party on water quality criteria of European fresh water fish. Water Res. 7:1011-1022.

FWPCA. 1968. Water quality criteria, report of the National Technical Advisory Committee. US Federal Water Pollution Control Administration. 
Fraser, Jack C. 1972. Regulated discharge and the stream environment. p. 263-286. In Oglesby, Ray T., Clarence A. Carlson and James A. McCann. (eds.) River ecology and man. Academic Press.

Gatschet, Albert S., Melville Jacobs and Leo Frachtenberg. 1945. The Kalapuya texts. University of Washington Publications in Arthropology \#1l. University of Washington.

Gaudy, Anthony J. 1972. Biochemical oxygen demand. p. 305332. In Mitchell, Ralph. (ed.) Water pollution microbiology. Wiley-Interscience. John Wiley and Sons, Inc.

Goering, John H. 1972. The role of nitrogen in eutrophic processes. p. 43-68. In Mitchell, Ralph, (ed.) Water pollution microbiology. Wiley-Interscience. John Wiley and Sons, Inc.

Goltermann, H. L. 1966. Influence of the mud on the chemistry of water in relation to productivity. p. 297-313. In Goltermann, H. L. and R. S. Clymo (ed) Chemical environments in the aquatic habitat. Amsterdam.

Hart, D. H., and R. C. Newcomb. 1965. Geology and groundwater of the Tualatin Valley, Oregon. US Geol. Sur. Water Supply Paper \#1967.

Hem, J. D., and W. H. Durum. 1973. Solubility and occurance of lead in surface water. Jour. AWWA. 65(8):562-568.

Hoffman, T., and H. Lees. 1953. The biochemistry of nitrifying organisms. Biochem. J. 54:579-580.

Hutchinson, G. Evelyn. 1967. A treatise on limnology, vol. I. John Wiley and Sons, Inc.

Hynes, H. B. N. 1970. The ecology of running waters. University of Totonto Press.

James, Daniel H., and G. Fred Lee. 1974. A model of inorganic carbon limitation in natural waters. Water, Air, and Soil Pollution. $3(3): 315-320$.

Keup, Lowell E. 1968. Phosphorous in flowing waters. Water Res. $2: 373-386$.

Klein, Aaron E. 1974. Sci. Am. 230(6):126-127.

Lagerwerff, J. V., and A. W. Sprect. 1970, Contamination of road-side soil and vegetation with cadmium, nickel, lead, and zinc. Env. Sci. and T. 4(7):583-586. 
Larson, Douglas, and John R. Donaldson. 1970. Waldo Lake, Oregon, a special study. Water Resources Research Institute. Oregon State University.

Larson, Douglas. 1974. A water quality survey of selected lakes in the sand dune region of Western Lane and Douglas Counties, 1972-1973. Oregon Department of Environmental Quality.

Lazrus, Allen L., Elizabeth Lorange, and James P. Lodge, Jr. 1970. Lead and other metal ions in United States precipation. Env. Sci, and T. 4(1):55-58.

Leland, H. V., S. S. Shukle and IJ. F. Shrimp. 1973. Factors affecting the distribution of lead and other trace elements in the sediments of southern Lake Michigan. p. 89130. In Singer, Phillip C. (ed.) Trace metals and metalorganic interactions in natural waters. Ann Arbor Science Publisher, Inc.

Leopold, Luna B. and W. B. Langbein. 1966. River meanders. Sci. Am. 214(6):60-73.

McArthur, Lewis A. 1943. Oregon geographical names. Ore. Hist. Soc. Quart. 44:345.

McHugh, Robert A. 1967. Biological determination of water quality in the Tualatin River. 1966. p. El-E12. In Tualatin River water quality control needs. Oregon State Sanitary Authority.

McHugh, Robert A. 1972. An interim study of some physical, chemical, and biological properties of selected Oregon lakes. Oregon Department of Environmental Quality.

Mackenthun, K. M. 1965. Nitrogen and phosphorous in water. US Department of Health, Education, and Welfare, Public Health Service.

Margalef, Ramon. 1969. Diversity and stability: a practice proposal to a model of interdependence, diversity, and stability. p. 25-37. In Ecological Systems. Brookhaven National Laboratory.

Miller, James D. 1930. Early Oregon scenes. Ore. Hist. Soc. Quart. 31:174.

Montgomery, H.A., and B. J. Borne. 1966. The inhibition of nitrification in the BOD test. J. P. O. C. Inst. Sew. Purif. 375-368. 
NOAA. 1972. Climatological data, Oregon. US Department of Commerce, National Oceanic and Atmospheric Administration Environmental Data Service. 78(6 to 12).

NOAA. 1973. Climatological data, Oregon. - US Department of Commerce, National Oceanic and Atmospheric Administration Environmental Data Service. 79 ( 1 to 9).

Odum, Eugene P. 197I. Fundamentals of ecology, 3rd ed. W. B. Saunders and Co.

OSSA. 1965. Some aspects of water pollution in Washington County, Oregon. Oregon State Sanitary Authority.

OSSA. 1966. Report on the Tualatin River Basin. Oregon State Sanitary Authority. (unpublished manuscript).

OSSA. 1967. Tualatin River basin water quality control needs. Oregon State Sanitary Authority.

OWC. 1974. Oregon Wildlife Commission. Personal Communication.

Painter, H. A. 1970. A review of the literature on inorganic nitrogen metabolism in microorganisms. Water Res. 4 ib) $393-450$.

Palmer, C. Mervin. 1969. A composite rating of algae tolerating organic pollution. J. Phycol. 5:78-82.

Pielou, E. C. 1969. An introduction to mathematical ecology. Wiley-Interscience.

Pitt, Robert E., and Gary Amy. 1973. Toxic materials analysis of street surface contaminants. Environmental Agency Technological Series, EPA-R2-73-283. US Environmental Protection Agency.

Poole, Robert W. 1974. An introduction to quantitative ecology. Academic Press.

Pound, C. E., and R. W. Crites. 1973. Characteristics of municipal effluents. p. 49-62. In Recylcing municipal sludges and effluents on Land. Proceedings of the Joint Conference, National Association of State Universities and Land Grant Colleges.

Reid, George K. 1961. Ecology of inland waters and estuaries. Van Nostrand Reinhold Company.

Rohde, W. 1948. Ervironmental requirements of fresh water planktonic algae. Symbol. Botan. Upseliensis. 10:1-149. 
Ruttner, Franz. 1963. Fundamentals in limnology. University of Toronto Press.

Saunders, George W., Francisco B. Troma, and Roger W. Bachman. 1962. Evaluation of a modified Cl4 technique for shipboard estimation of photosynthesis in large lakes. Great Lakes Research Division Publication \#8. Institute of Science and Technology. University of Michigan.

Sawyer, C. N. 1947. Fertilization of lakes by agricultural and urban drainage. J. New England Water Works Assoc. $6 I(2): 109-127$.

Schlicker, Herbert B., and Robert J. Deacon. 1967. Engineering geology of the Tualatin Valley region, Oregon. Bulletin \#60. Oregon Department of Geological and Mineral Industry.

Sci. News. 1973. As dirty as new fallen snow. 103(21):341.

STR. 1956. A tri-county master plan of sewerage for metropolitan areas of Clackamas, Multnomah, and Washington Counties, Oregon. Stevens, Thompson, and Runyan Engineering Consultants.

STR. 1969. Tualatin basin water and sewerage master plan. Stevens, Thompson, and Runyan Engineering Consultants.

Stratton, Frank and Perry McCarty. 1967. Predictions of nitrification effects on the DO balance of streams. Env. Sci. and T. I(5):405-410.

Stumm, Werner, and James Morgan. 1970. Aquatic chemistry. John Wiley and Sons, Inc.

Swaine, D. J. 1962. Commonw. Bur. Soil Sci. Tech. Comm. 52. Commonwealth Agricultural Bureau.

Swift, C. H., III. 1971. Appraisal of streamflow in the Tualatin River basin, Washington County, Oregon. US Geological Survey.

Thompson, Kenneth E., James Hutchinson, John D. Fortune, and Robert W. Phillips. 1966. Fish Resources of the Willamette basin, Oregon. Oregon State Game Commission.

USACE. 1953. Review of survey report on the Tualatin River, Oregon. US Army Corps of Engineers, Portiand District. 
USACE. 1969. Floodplain information on the Tualatin River and its tributaries, Washington County, Oregon. US Anmy Corps of Engineers, Portland District.

USBR. 1956. Tualatin project, proposed report. US Bureau of Reclamation, US Department of the Interior.

USBR. 1963. Tualatin project, Oregon. US Bureau of Reclamation, US Department of the Interior.

USGS. 1956. Preliminary report on the groundwater resources of the Tualatin Valley, Oregon. US Geological Survey, Office of the State Engineer, Salem, Oregon.

USGS. 1973. Water resources data for Oregon, Part I, Surface water records. US Geological Survey, US Department of the Interior.

USHEW. 1962. Preliminary investigation of muncipal and industrial water supply and stream quality control requirements and benefits associated with multiple purpose studies of the proposed Scoggin Reservoir, Tualatin Project, Washington County, Oregon. US Departinent of. Health, Education, and Welfare.

Vinogradov, A. B. 1959. The geochemistry of rare and dispersed chemical elements in soils, 2 nd ed. Consultants Bureau. New York.

WACES. 1973. Washington County farm income for 1973. Washington County Agricultural Extension Service.

Watson, E. R., E. C. Eckman, A. C. Fluharty, and C. U. Ruzek. 1923. Soil survey of Washington County, Oregon. Bureau of Soils. US Department of Agriculture.

Welch, Paul S. 1948. Limnological methods. The Blakinston Company.

Wezernak, C. T. and J. J. Gannon, 1967. Oxygen, nitrogen relationships in autotrophic nitrification. Appl. Microb. 15:1211-1215.

Wezernak, C. T., and J. J. Gannon. 1968. Evaluation of nitrification in streams. J. San. Eng. Div. Pro. Amer. Soc. Civil Engrs. 94 (SAS):883-895.

Wilhm, J. L., and T. C. Doris. 1968. Biological parameters for water quality criteria. Bio-Sci. 18:477. 
Youngberg, C. T., M. E. Harward, G. H. Simonson, D. Rai, P. C. KIingeman, D. W. Larson, H. K. Phinney, J. R. Bell. 1971. Hills Creek Reservoir turbidity study. Water Resources Research Institute, Oregon State University.

Zwick, David. 1971. Water wasteland. Bantam Books. 


\section{APPENDIX A}

STATISTICAL DATA FOR DIVERSITY ANALYSIS

$\begin{array}{lccc} & \overline{\mathrm{X}} & \mathrm{s}^{2} & \mathrm{~s} \\ \text { Gaston } & 3.0 & 0.29 & 0.53 \\ \text { Dilley } & 3.0 & 0.07 & 0.27 \\ \text { Cornelius } & 3.3 & 0.11 & 0.34 \\ \text { Hillsboro } & 3.3 & 0.10 & 0.32 \\ \text { Rood Road } & 3.0 & 0.99 & 0.99 \\ \text { Farmington } & 3.3 & 0.07 & 0.27 \\ \text { August 1972 } & 2.8 & 1.24 & 1.11 \\ \text { October 1972 } & 3.2 & 0.20 & 0.45 \\ \text { December 1972 } & 3.2 & 0.10 & 0.32 \\ \text { March 1973 } & 3.0 & 0.22 & 0.47 \\ \text { May 1973 } & 3.4 & 0.10 & 0.32 \\ \text { June 1973 } & 3.1 & 0.18 & 0.42 \\ \text { July 1973 } & 3.1 & 0.10 & 0.32 \\ \text { August 1973 } & 3.2 & 0.20 & 0.45\end{array}$


TABLE FOR TWO-WAY ANALYSIS OF VARIANCE

\begin{tabular}{l|c|c|c|c|c} 
Source & d.f. & SS & MS & $F$ & $F_{0.05}$ \\
\hline \begin{tabular}{l|l} 
Row \\
Month
\end{tabular} & 7 & 1.2 & 0.24 & 0.77 & 2.31 \\
\hline $\begin{array}{l}\text { Column } \\
\text { Station }\end{array}$ & 5 & 1.2 & 0.17 & 0.55 & 2.51 \\
\hline Error & 33 & 10.2 & 0.31 & & \\
\hline Total & 45 & 12.6 & & &
\end{tabular}

Since each $F_{\text {calc. }}<F_{0.05}$, there is no difference in variances. There is no variance in the diversity of the river from month to month or from station to station. 
APPENDIX B

CHECK LIST OF THE NET PLANKTON Tualatin River, June 1972 to

September, 1973

\section{ORGANISM}

CHLOROPHYTA (green algae)

Actinastrum sp. Langerhein

Actinastrum gracilimum G.M. Smith

Ankistrodesmus falcatus (Corda) Ralfs

Cinroococcus sp. Naegeli

Closterium sp. Nitzsch

Cosmarium sp. Corda

Crucigenia sp. Morren

Dictyosphaerium Ehrenbergianum Naegeli Eudorina elegans Ehrenberg

Gonium sp. Mueller
GASTON

DILLEY

CORNELIUS

HILLSBORO

$x$

\section{ROOD ROAD FARMINGTON}

$x$

$\mathbf{x}$

$\mathbf{x}$

Kirchneriella Zunaris (Kirch.) Moebius 
ORGAiNISM

Micrasterias sp. Agardh

Micractinium posizlum Fresenius

Mougeotia sp. (Agardh) Wittrock

Mougeotiopsis calospora Palla

Oedogonium sp. Link

Pandorina sp. Bory

Peaiastrum sp. Meyen

Pediastrum duplex Meyen

Pediastrum tetras (Ehrenb.) Palfs

Roya obtusa (Breb.) W. and G. S. West

Scenedesmus quadricauds (Turp) de Brebission

Selenastrum sp. Reinsch

Spirogyra sp. Link

Spirogyra pseudo-floxidina Prescott

Spondylosium sp. de Brebisson

Stigeoclonium sp. Kuetzing

Staurastrum sp. Meyen

Tetraedron sp. Kuetzing

\section{GASTON}

DILLEY

$x$

$\mathbf{x}$

$x$

$x$

$\mathbf{x}$

$\mathrm{x}$

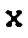

$\mathbf{x}$

$\mathrm{x}$

$\mathbf{x}$

$\mathbf{x}$

$x$
ROOD ROAD

FARIINGTON

$\mathrm{x}$ 


\section{ORGANISM}

viothrix sp. Kuetzing

Volvox sp. Linnaeus

zoochlorelza sp. Brandt

CHRYSOPHYTA (yellow-green algae)

Diatoms

Achnanthes spp. Bory

Achnanthes brevipes Agardth

Amphiproma ornata Bailey

Asterionella formosa Hassell

Bacizlaria paradoxa Gmelin

Coccenois sp. E'hrenberg

cyclotelza sp. Kuetzing.

Cymatopleura solea (Breh.) W. Smith

Cymbelza sp. Agardh

Çmbella aspera (Ehr.) Cleve

Cymbelza prostrata (Berkley) Cleve

Cymbella tumida (Breb.) v.Heurck
GASTON

DILLEY

$\mathbf{x}$

CORNELIUS

$\mathbf{x}$

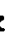

$\mathbf{x}$

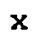

$x$

$\mathbf{x}$ $x$

$x$

$x$

$x$

$x$

$x$

$x$

$\mathbf{x}$

$\mathbf{x}$

$x$

$x$

$x$

$x$

HILLSBORO

ROOD ROAD

x

$x$

$\mathbf{x}$

$\boldsymbol{x}$ 


\section{ORGANISM}

\section{Cymbella ventricosa Kuetzing}

Diatoma hiemle (Lyngbye) Heibeng

Diatoma vulgare Bory

Epithemia sp. Brebisson

Eunotia sp. Ehrenberg.

Eunotia arcus Ehrenberg

Eunotia tridentula var. perminuta Grunow

Eunotia tridentula var. persusilla Grunow

Eragizlaria sp. iyngbye

Eragizlaria crotenensis Kitton

Erustulia rhomboides (Ehr.) de Toni

Gomphonema sp. Agardh

Gyrosigma sp. Hassell

Hannaea sp. Patr. gen. nov.

Hannaea arcus var. amphioxys (Rabh.) Patr. Melosira distans (Ehr.) Kuetzing comb. nov.

Melosira granulata (Ehr.) Ralfs

GAST
$\times$
$x$
$x$
$x$
$x$
$x$
$x$
$x$
$x$

DILLEY

$\mathbf{x}$

$\mathbf{x}$

$\mathbf{x}$

$\mathbf{x}$

$x$

$\mathbf{x}$

x
CORNELIUS

$\mathrm{x}$

$\mathbf{x}$

$x$

$x$

$\mathbf{x}$

$\mathrm{x}$

$x$

$x$

$\mathbf{x}$ $x$

$\mathrm{x}$

$x$

$x$

$\mathrm{x}$

x

$x$

$\mathrm{x}$

$x$

$x$

x

$x$

$x$

$\mathrm{x}$
GTON

$x$


ORGANISM

Melosira italica (Ehr.) Kuetzing

MeZosira varians C. A. Agardh

Meridion circulare (Ra.lfs) v. Heurck

Navicula spp. Bory

Nitzschia spp. Hassell

Nitzschia acicularis W. Smith

Nitzschia acuta Hantzsch

Nitzschia filiformis (W. Smith) Husted

Nitzschia sigma (Kütz.) W. Smith

Nitzschia sigmoidea (Ehr.) W. Smith

Pinnuzaria spp. Ehrenberg

Rhiocosphenia curvata (Kütz.) Grun.

Rhopalodia sp. 0. Muller

Stephanodiscus spp. Ehrenberg

Surirezza spp. Turpin

Surirelza ovata kuetzing

Synedra spp. Ehrenberg

Synedra ulna (Nitzsch) Ehrenberg

$\begin{array}{cc}\text { GASTON } & \text { DILLE } \\ \mathbf{x} & \mathbf{x} \\ \mathrm{x} & \mathrm{x} \\ & \mathrm{x} \\ \mathrm{x} & \mathrm{x} \\ \mathrm{x} & \mathrm{x} \\ \mathrm{x} & \mathrm{x}\end{array}$

COR

$\mathrm{x}$
$\mathrm{x}$
$\mathrm{x}$
$\mathrm{x}$
$\mathrm{x}$
$\mathrm{x}$
$\mathrm{x}$

HILLSBORO
$\mathrm{x}$
$\mathrm{x}$
$\mathrm{x}$
$\mathrm{x}$
$\mathrm{x}$
$\mathrm{x}$

ROOD ROAD

FARMINGTON

$x$
$x$
$x$
$x$
$x$
$x$

$x$

$x$

$\mathbf{x}$

x

$\mathbf{x}$

$\mathbf{x}$

$\mathbf{x}$

$x$

x

x

$\mathbf{x}$

$\mathbf{x}$

$x$

$x$

$\mathbf{x}$

x

$\mathrm{x}$

$\mathbf{x}$

$x$

$x$

$\mathbf{x}$ 


\section{ORGANISM}

Synedra ulna var. contracta Husted

Tabelzaria sp. Ehrenberg

Tabellaria fenestrata (Lyngb.) Kuetzing

Other

Chrysosphrerezza Zongispina Lauterborn

Dinobryon sp. Ehrenberg

Malzomonas sp. Perty

Synura uvelia Ehrenterg

Vaucheria sp. DeCandolle

EUGLENOPHYTA (euglenoids)

Eugelna spp. Ehrenberg

Euglena acus Ehrenberg.

Euglena tripleris

Phagus spp. Dujardin

Phagus Birgei Prescott

Trachelomonas spp. Ehrenberg

\section{GASTON}

DILLEY

CORNELIUS

HILLSBORO

ROOD ROAD

FARMINGTON

$\mathbf{x}$

$\mathbf{x}$ 
ORGANISM

GASTON DILLEY CORNELIUS HILLSBORO ROOD ROAD FARMINGTON

PYRRHOPHYTA (yellow-brown algae)

Peridinium sp. Ehrenberg

CYANOPHYTA (blue-green algae)

Aphanizomenon flos-aquae (L.) Ralfs

Anabaena affinis Lemmermann

Anabaena circinalis Rabenhorst

Microcystis aeruginosa Kuetzing

Phormidium sp. Kuetzing

oscillatoria spp. Vaucher

oscillatoria-like filament

spirulina sp. Turpin

\section{PROTOZOA}

Acanthocystis sp. Carter

$\mathbf{x}$

Difflugia sp. Leclerc. 
ORGANISM

Stentor sp. Oken

Vorticezla sp. Linneus

ARTHROPODA

Alona sp. Baird

Bosmina Longirostris (O.F. Muller)

Canthocamptris (Westwood)

Daphnia sp. (O. F. Muller)

Hydrachna sp. (0. F. Mulier)

Simocephialus sp. Schodler

Other

diptera larvae

tardigrade

\section{ROTIFERS}

Branchionus plicatilis Pallas

Uchlanis sp. Ehrenberg

Kereteila sp. Bory de St. Vincent (Ehrenberg)

Rotaria sp. Scopoli

Nematodes
GASTON

DILLEY

CORNELIUS

$\mathrm{x}$

$x$

$\mathbf{x}$

$\mathbf{x}$

x

$\mathbf{x}$ $x$

ROOD ROAD 
APPENDIX $C$

\section{TAXONOMIC REFERENCES}

Edmondson, W. T. (ed.). 1959. Ward and Whipple--Freshwater Biology. 2nd ed. John Wiley \& Sons, Inc.

Hustedt, Friedrich. 1930. Die Susswasser-Flora Mitteleuropas, Heft 10: Bacillariophyta (Diatomeae). Verlag von Gustav Fischer.

Patrick, Ruth and Charles W. Reimer. 1966. The diatoms of the United States. Monographs of the Academy of Natural Science of Philadelphia l(13).

Prescott, G. W. 1962. Algae of the western Great Lakes area. William C. Brown Co.

Prescott, G. W. 1970. The freshwater algae. William C. Brown Co.

Randall, Warren R. and Robert F. Keniston. 1970. Manual of Oregon trees and schrubs. Oregon State University Book Store, Inc.

Smith, Gilbert M. 1950. Freshwater algae of the United States. McGraw-Hill Book Co. 
Apprsutx A

LISTIKG OF RAY DATA

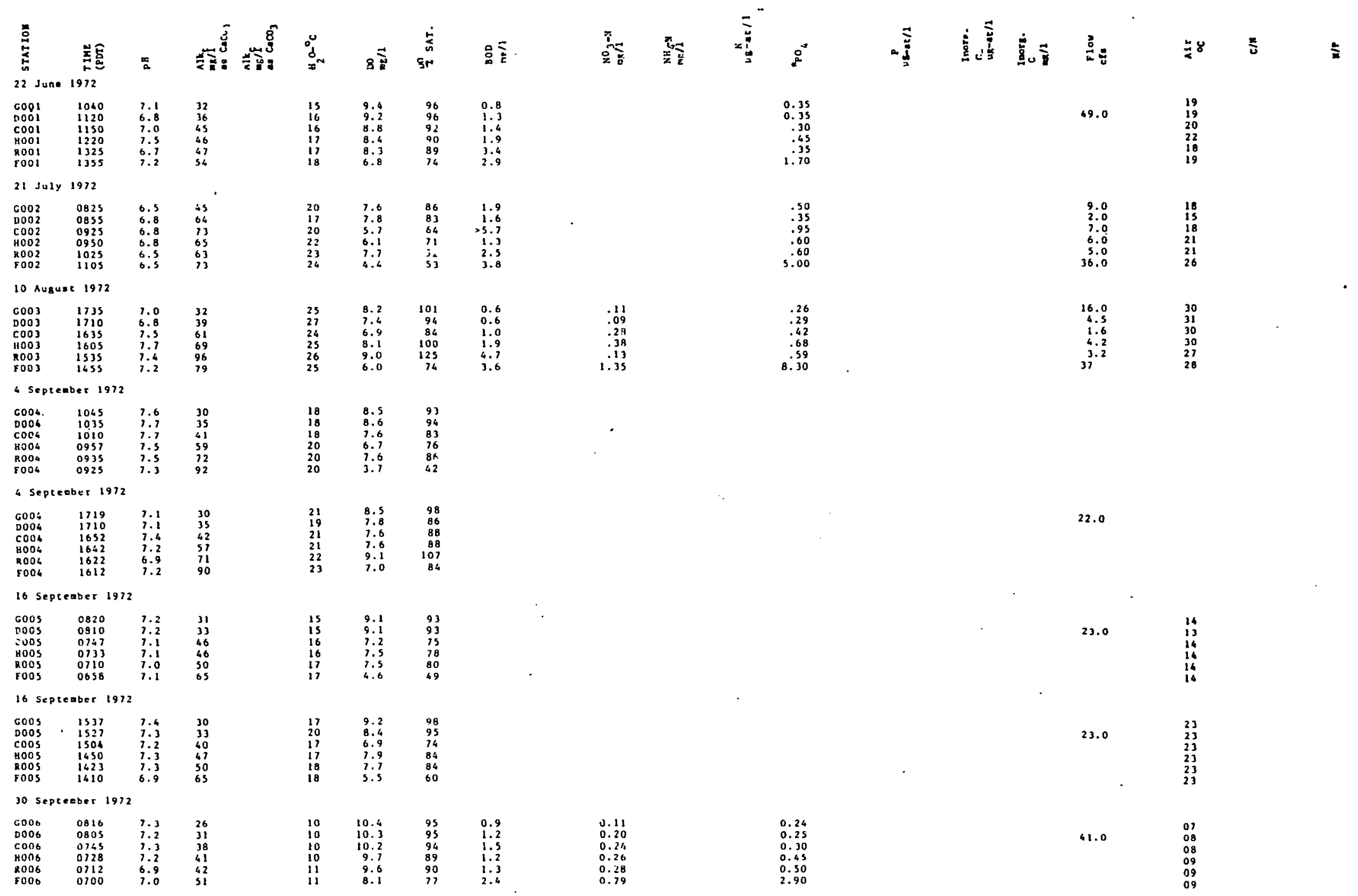




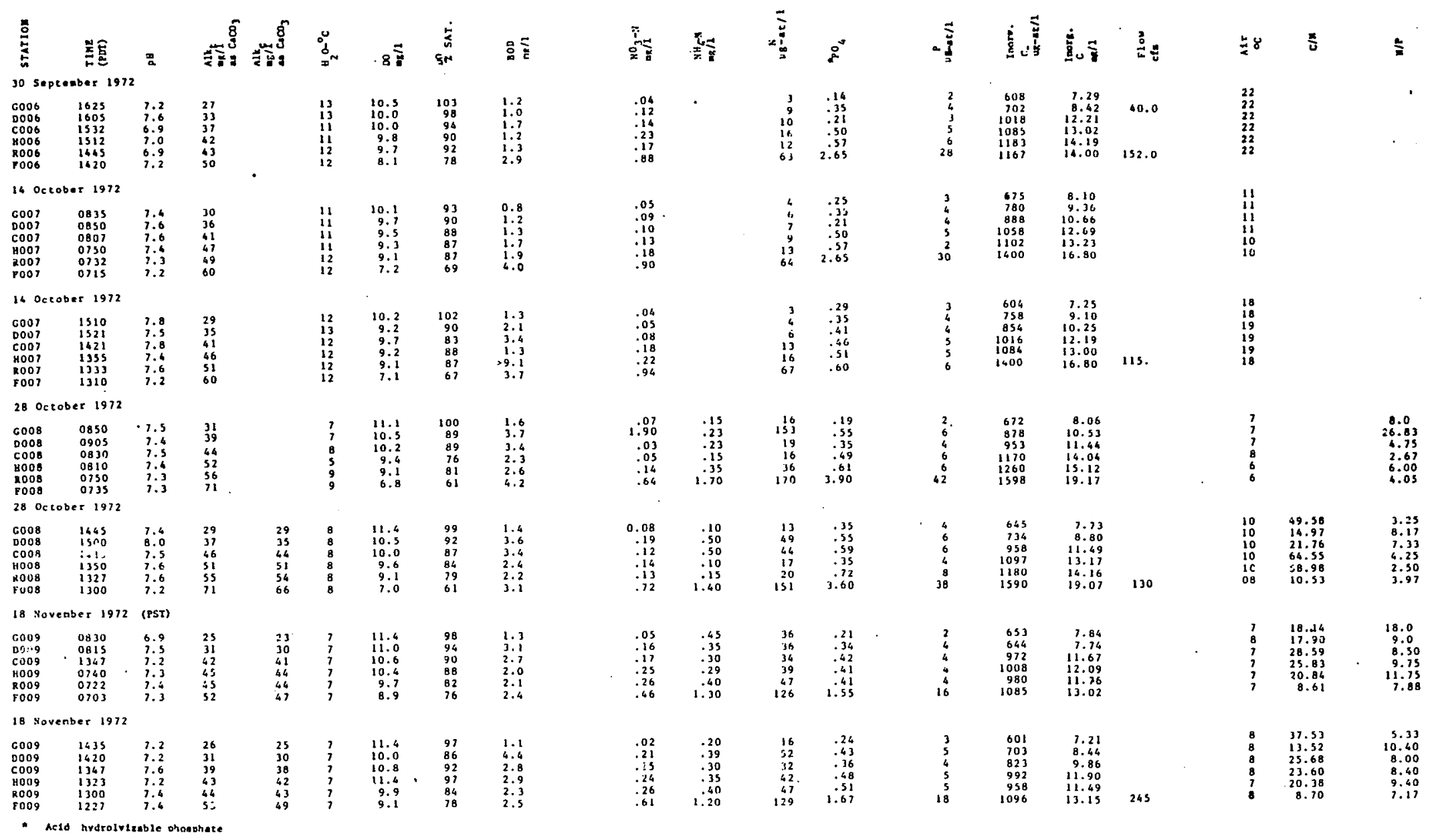




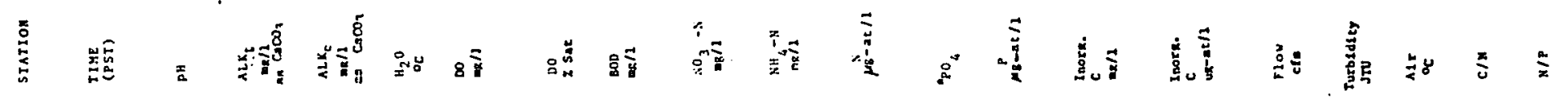

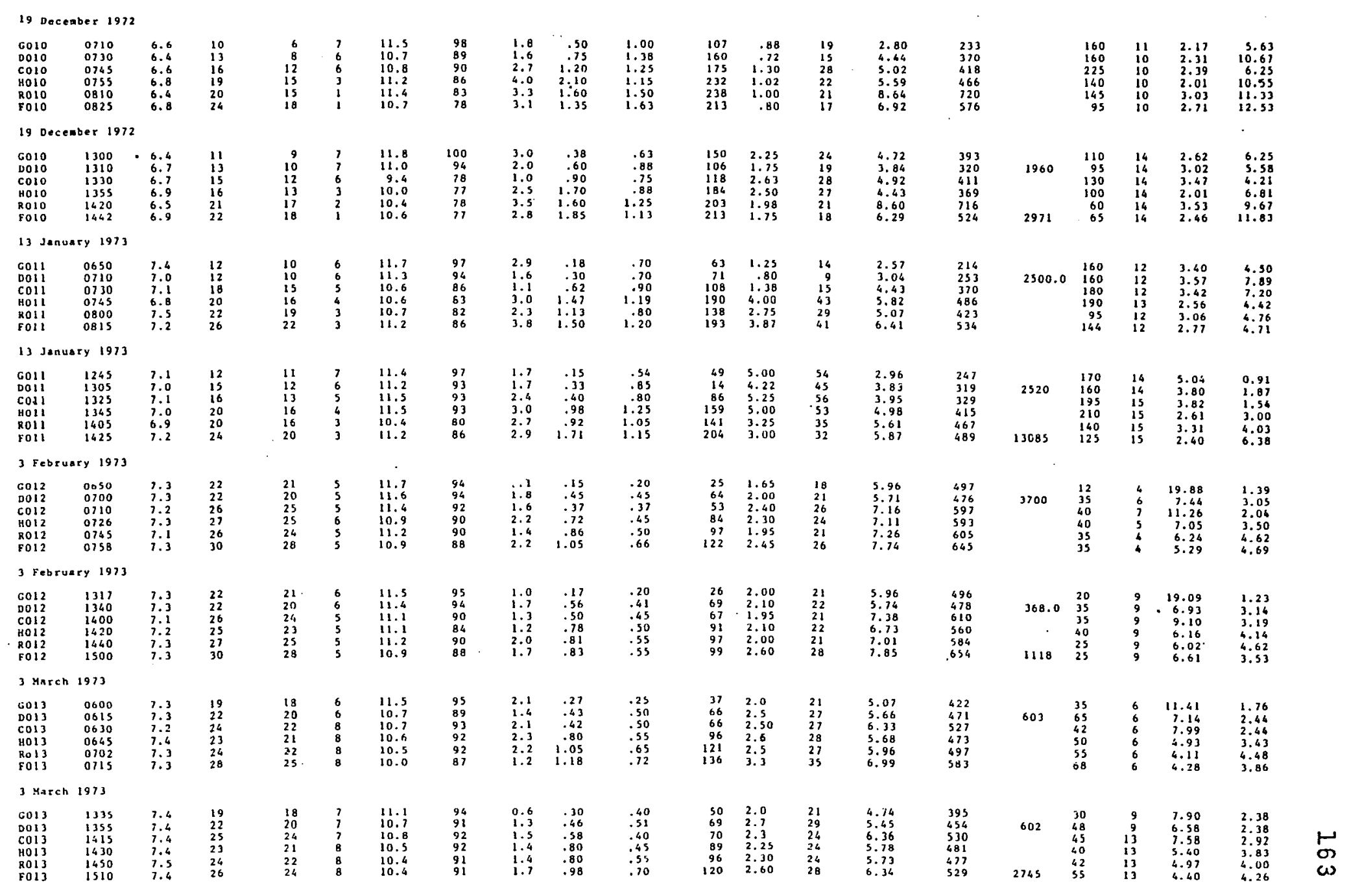




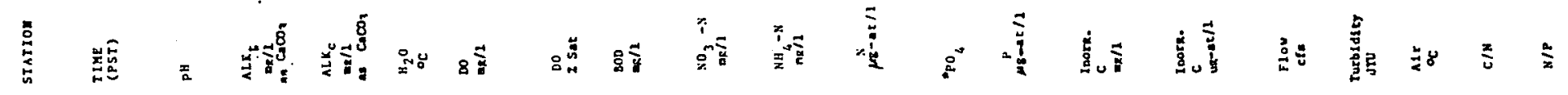

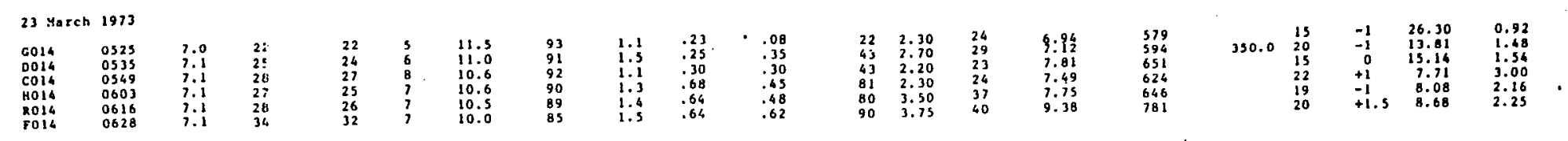

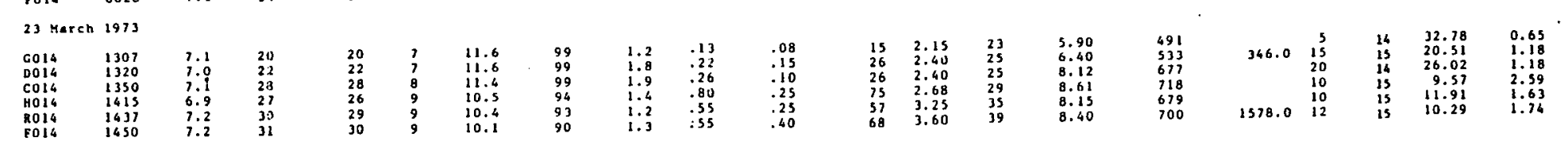

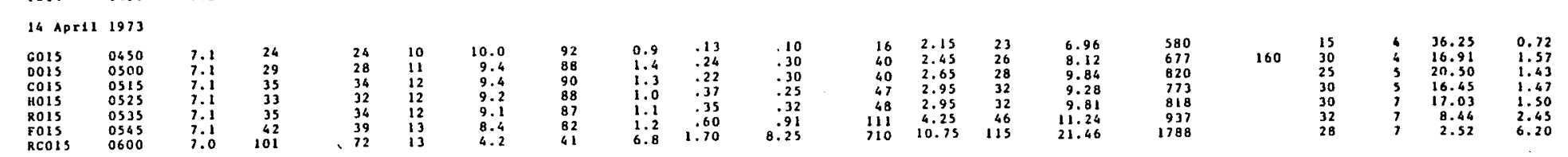

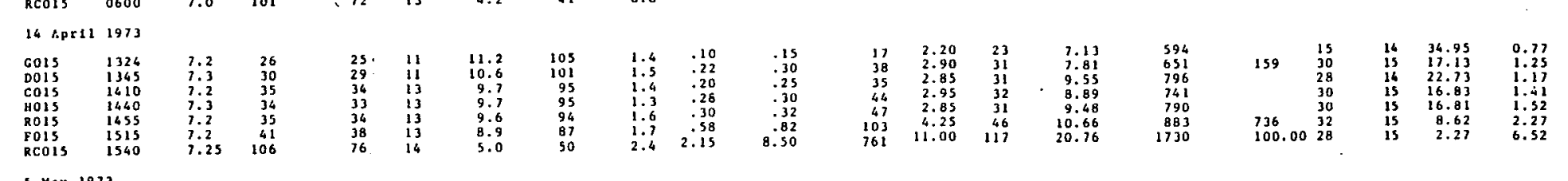

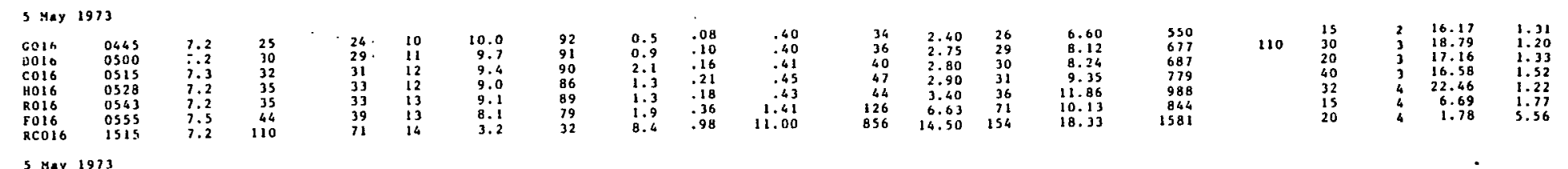

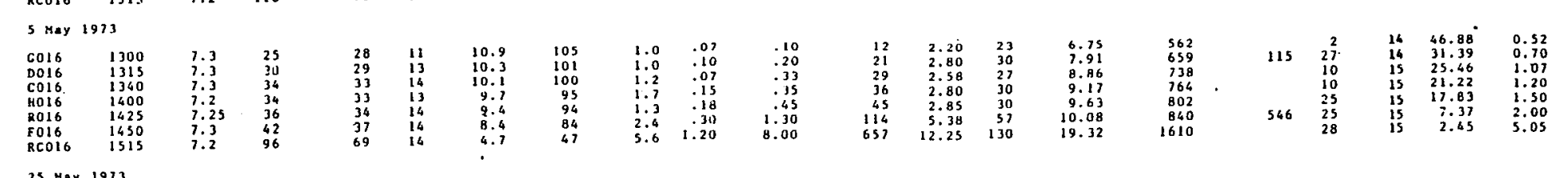

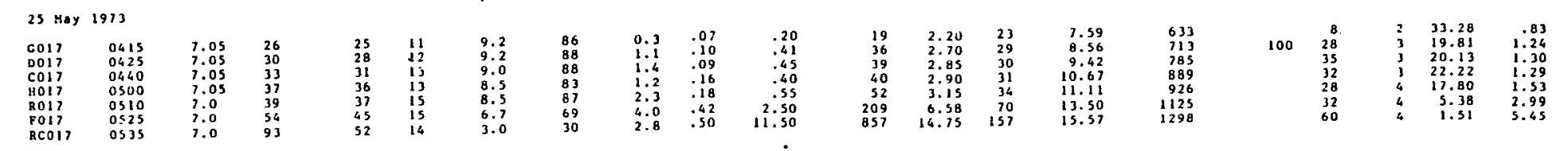




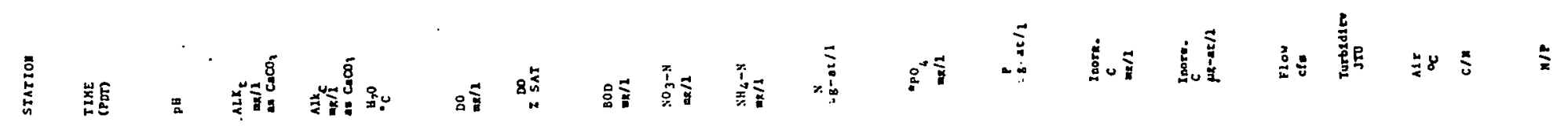

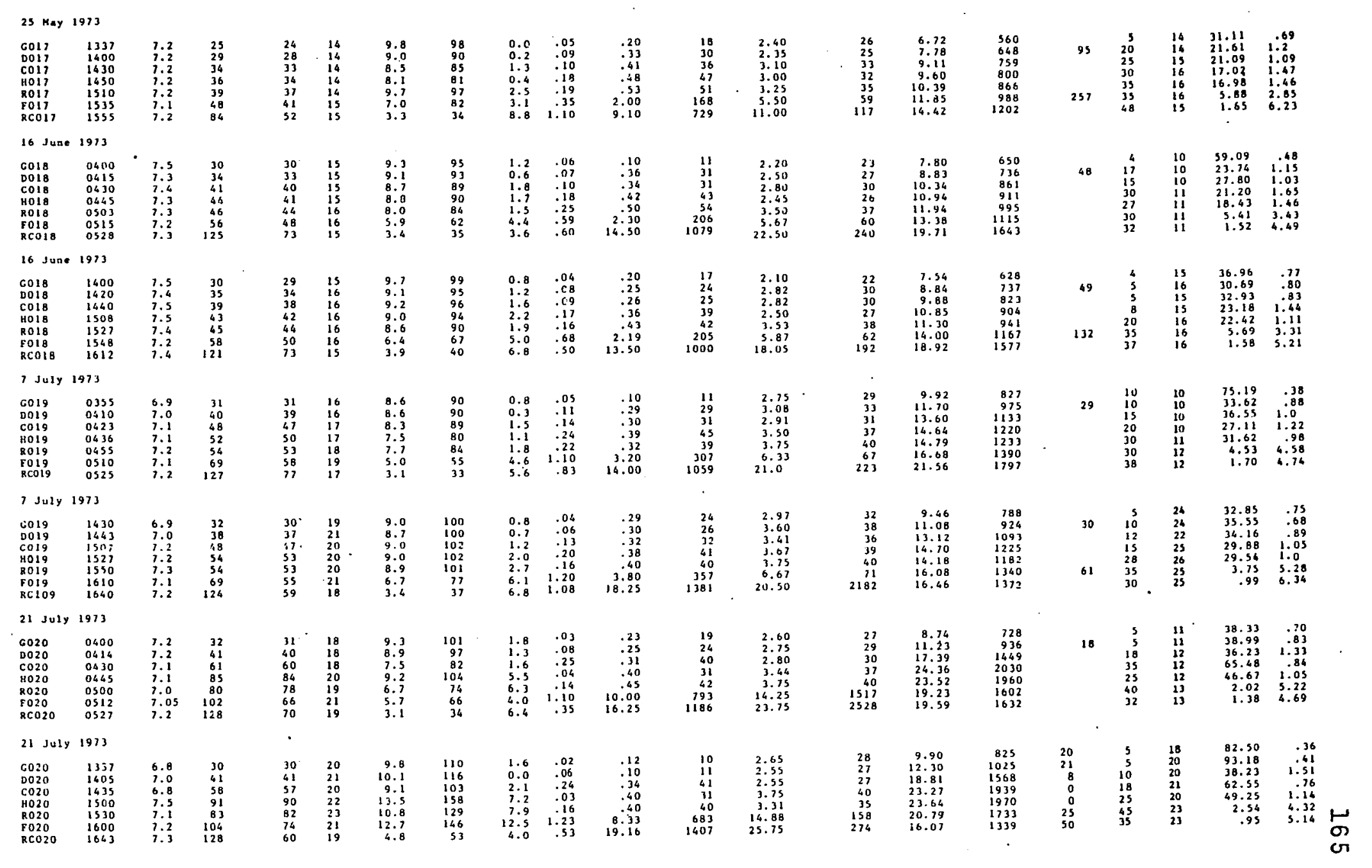




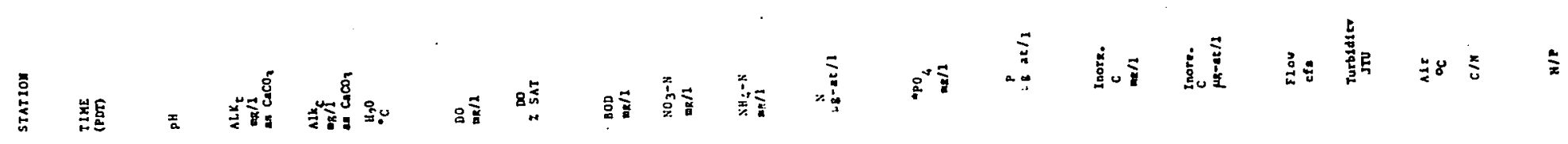

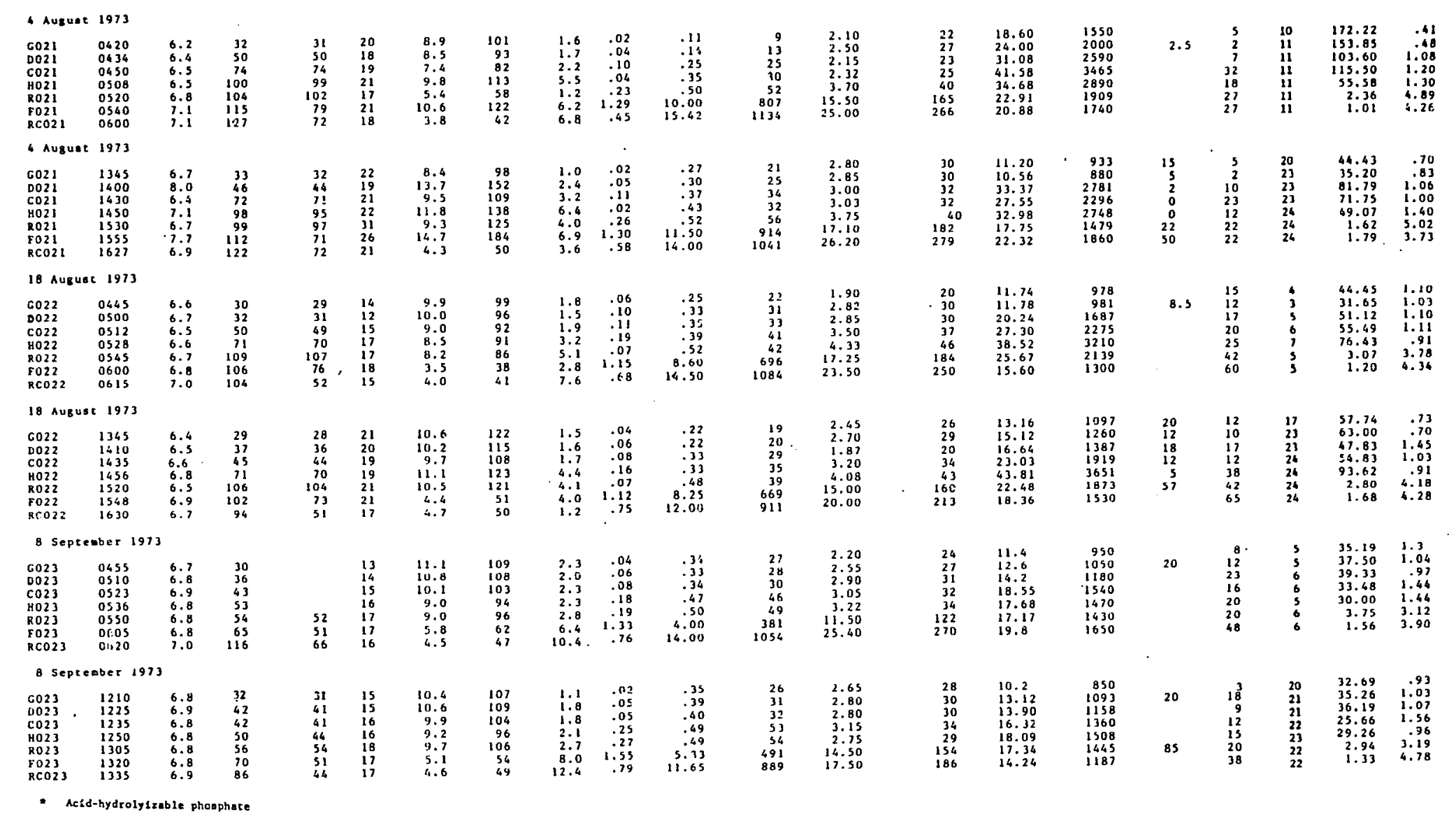

